LITHOLOGIC, NATURAL-GAMMA, GRAIN-SIZE, AND WELL-CONSTRUCTION DATA FOR WRIGHT-PATTERSON AIR FORCE BASE, OHIO

By Denise H. Dumouchelle and Jeffrey T. de Roche

U.S. GEOLOGICAL SURVEY

Open-File Report 91-181

Prepared in cooperation with

WRIGHT-PATTERSON AIR FORCE BASE
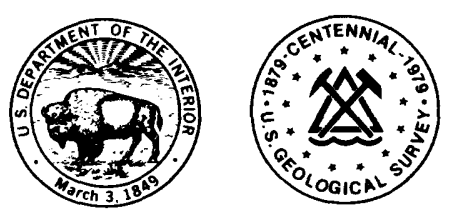

Columbus, Ohio 
U.S. DEPARTMENT OF THE INTERIOR

MANUEL LUJAN, JR., Secretary

U.S. GEOLOGICAL SURVEY

Dallas L. Peck, Director

For additional information write to:

District Chief

Water Resources Division

U.S. Geological Survey

$975 \mathrm{~W}$. Third Avenue

Columbus, $\mathrm{OH}$ 43212-3192
Copies of this report can be purchased from:

U.S. Geological Survey Books and Open-File Reports Box 25425, Federal Center Building 810

Denver, CO 80225 
CONTENTS

Page

Abstract---- -

Introduction--

Geologic setting---------

Methods of well construction and geologic sampling---------- 5

Lithologic, natural-gamma, grain-size, and

well-construction data--

References cited--_- 94

\section{ILLUSTRATIONS}

Figure 1. Map showing location of study area and well clusters-----------

2. Diagram showing natural-gamma and lithologic logs for well GR-315 (cluster 1)-- 11

3-5. Graphs showing grain-size distributions of

6-8. Construction diagrams for:

6. Well GR-316 (cluster 1)--- 17

7. Well GR-317 (cluster 1)------------------- 18

8. Well GR-315 (cluster 1)----------------- 19

9. Diagram showing natural-gamma and lithologic logs for well GR-314 (cluster 2)-- 20

10. Graphs showing grain-size distributions of sediment samples from well GR-3l4 (cluster 2)--

11-13. Construction diagrams for:

11. Well GR-318 (cluster 2)--_- 24

12. Well GR-319 (cluster 2)------------------ 25

13. Well GR-314 (cluster 2)---------------- 26

14. Diagram showing natural-gamma and lithologic logs for well GR-303 (cluster 3) 27

15. Graphs showing grain-size distribution of a
sediment sample from well GR-303 (cluster 3)--- 28

16-17. Construction diagrams for:

16. Well GR-320 (cluster 3)-- 29

17. Well GR-303 (cluster 3)------- 30

18. Diagram showing natural-gamma and lithologic logs for well GR-304 (cluster 4) 31

19. Graphs showing grain-size distributions of sediment samples from well GR-304 (cluster 4)-- 34

20-22. Construction diagrams for:

20. Well GR-321 (cluster 4)-- 35

21. Well GR-322 (cluster 4)--------------- 36

22. Well GR-304 (cluster 4)------- 37

23. Diagram showing natural-gamma and lithologic logs for well GR-305 (cluster 5) 38

24. Graphs showing grain-size distributions of sediment samples from well GR-305 (cluster 5)-- 


\section{ILLUSTRATIONS--Cont inued}

Page

25-27. Construction diagrams for:

25. Well GR-323 (cluster 5)

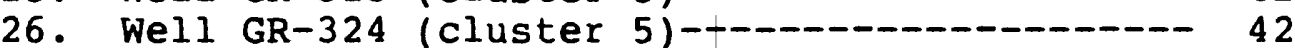

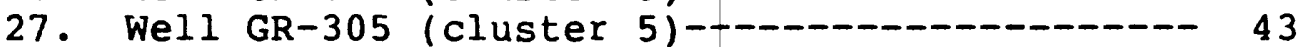

28. Diagram showing natural-gamma and lithologic

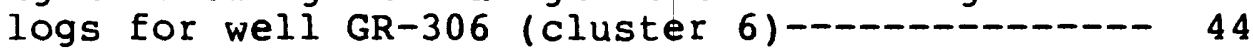

29-31. Graphs showing grain-size distributions of

32-35. Construction diagrams for:

32. Well GR-330 (cluster 6)-_............- 50

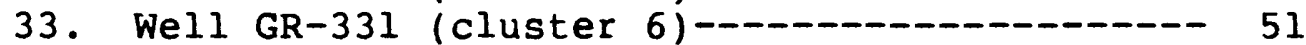

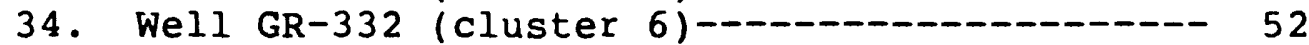

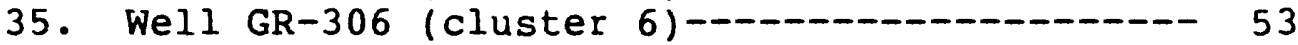

36. Diagram showing natural-gamma and lithologic logs for well GR-307 (cluster 7)--- 54

37-38. Graphs showing grain-size distributions of sediment samples from well GR-307 (cluster 7)-- 57

39-42. Construction diagrams for:

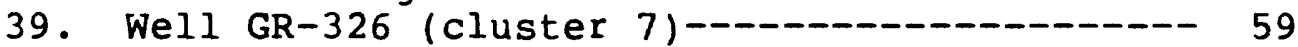

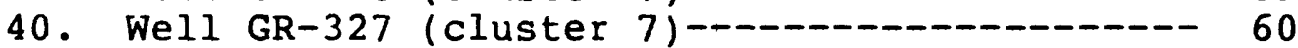

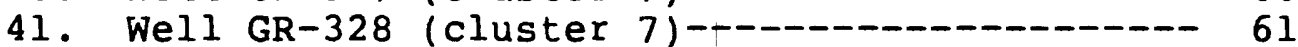

42. Well GR-307 (cluster 7)-_-_-_-_- 62

43. Diagram showing natural-gamma and lithologic logs for well GR-308-_-_- 63

44. Construction diagram for well GR-308--_---_---- 64

45. Diagram showing natural-gamma and lithologic

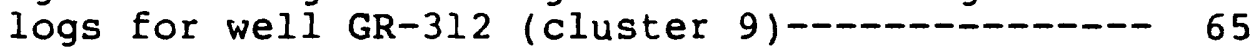

46-47. Construction diagrams for:

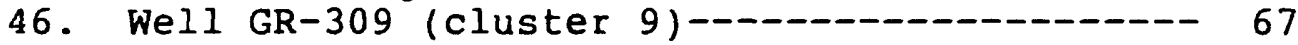

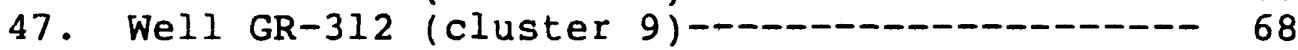

48. Diagram showing natural-gamma and lithologic logs for well GR-310-_- 69

49. Construction diagram for well GR-310--------- 70

50. Diagram showing natural-gamma and Iithologic logs for well GR-311 (cluster 11)-_------ 71

51-53. Graphs showing grain-size distributions of sediment samples from well GR-3ll

(cluster 11)

54-57. Construction diagrams for:

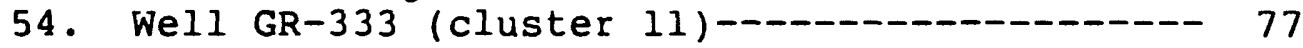

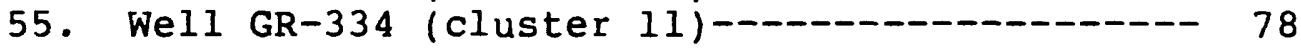

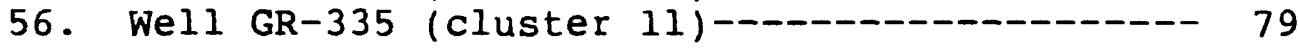

57. Well GR-311 (cluster 11)---- 80

58. Diagram showing natural-gamma and lithologic logs for well MT-133 (cluster 12)-------- 81

59-61. Graphs showing grain-size distributions of sediment samples from well MT-133

(cluster 12) 
62-64. Construction diagrams for:

62. Well MT-152 (cluster 12)-_-_-_._- 87

63. Well MT-153 (cluster 12)-_-_-_-_-_--- 88

64. Well MT-133 (cluster 12)-_- 89

65. Diagram showing natural-gamma and lithologic logs for well GR-313 (cluster 13)-...-.-. 90

66. Graphs showing grain-size distributions of sediment samples from well GR-313 (cluster 13)

67-68. Construction diagrams for:

67. Well GR-329 (cluster 13)-_-_-_-_-_-_-_ 92

68. Well GR-313 (cluster 13)-_-n 93

\section{TABLES}

Table 1. Generalized geologic section of the WrightPatterson Air Force Base area--

2. Permeability of selected sediment samples analyzed by use of a triaxial chamber permeameter--_-- 6

3. Summary of selected well-construction data--_---- 9

\section{CONVERSION FACTORS AND VERTICAL DATUM}

\section{Multipy}

inch (in.)

foot ( $f t$ )

mile ( $\mathrm{mi}$ )

acre

foot per second ( $f t / s$ )

pound per square inch

$\left(1 b /\right.$ in $\left.^{2}\right)$

pound per cubic foot

$\left(1 b / f t^{3}\right)$
By

$$
\begin{array}{rl}
25 & .4 \\
0.3048 \\
1.609 \\
4047.0 \\
0.3048
\end{array}
$$

6895.0

16.02 


\title{
LITHOLOGIC, NATURAL-GAMMA, GRAIN-SIZE, AND WELL-CONSTRUCTION DATA FOR WRIGHT-PATTERSON AIR FORCE BASE, OHIO
}

By Denise H. Dumouchelle and Jeffrey T. de Roche

\begin{abstract}
Wright-Patterson Air Force Base, in southwestern Ohio, overlies a buried-valley aquifer. The U.S. Geological Survey installed 35 observation wells at 13 sites on the base from fall 1988 through spring 1990. Fourteen of the wells were completed in bedrock; the remaining wells were completed in unconsolidated sediments. Split-spoon and bedrock cores were collected from all of the bedrock wells. Shelby-tube samples were collected from four wells. The wells were drilled by either the cable-tool or rotary method. Data presented in this report include lithologic and natural-gamma logs, and, for selected sediment samples, grain-size distributions of permeability. Final wellconstruction details, such as the total depth of well, screened interval, and grouting details, also are presented.
\end{abstract}

\section{INTRODUCTION}

Wright-Patterson Air Force Base (WPAFB) encompasses about 8,500 acres of Montgomery and Greene Counties in southwestern Ohio (fig. 1). WPAFB is divided into three administrative areas; Areas $A$ and $C$ are the main part of the base, and Area $B$ is a smaller area southwest of the main part. WPAFB was built over a highly productive glacial aquifer within the Mad River valley. WPAFB and a number of cities and industries use this aquifer for water supply. Although numerous wells have been drilled on and around the base, data on the regional ground-water-flow system are limited.

In 1987, the U.S. Geological Survey (USGS) began work on a regional ground-water study. As part of the regional study, the USGS installed 35 observation wells at 13 sites on WPAFB (fig. 1) from fall 1988 through spring 1990. The first well at each site was completed in bedrock. The geological data obtained from the bedrock wells were used to determine whether additional wells were necessary to define the head distribution in the unconsolidated sediments at that site. A site at which more than one well was constructed is called a well cluster or cluster. The clusters are numbered 1 through 13; individual wells are identified by a two-letter code and a three-digit number (for example, GR-316). "Clusters" 8 and 10 (wells GR-308 and GR-310) consist of a single well each, and, as such, are not truly well clusters. Cluster 9 consists of two wells completed in the bedrock. The remaining clusters consist of two to four wells, of which one well is completed in the bedrock and the remaining wells are completed in the unconsolidated sediments. 


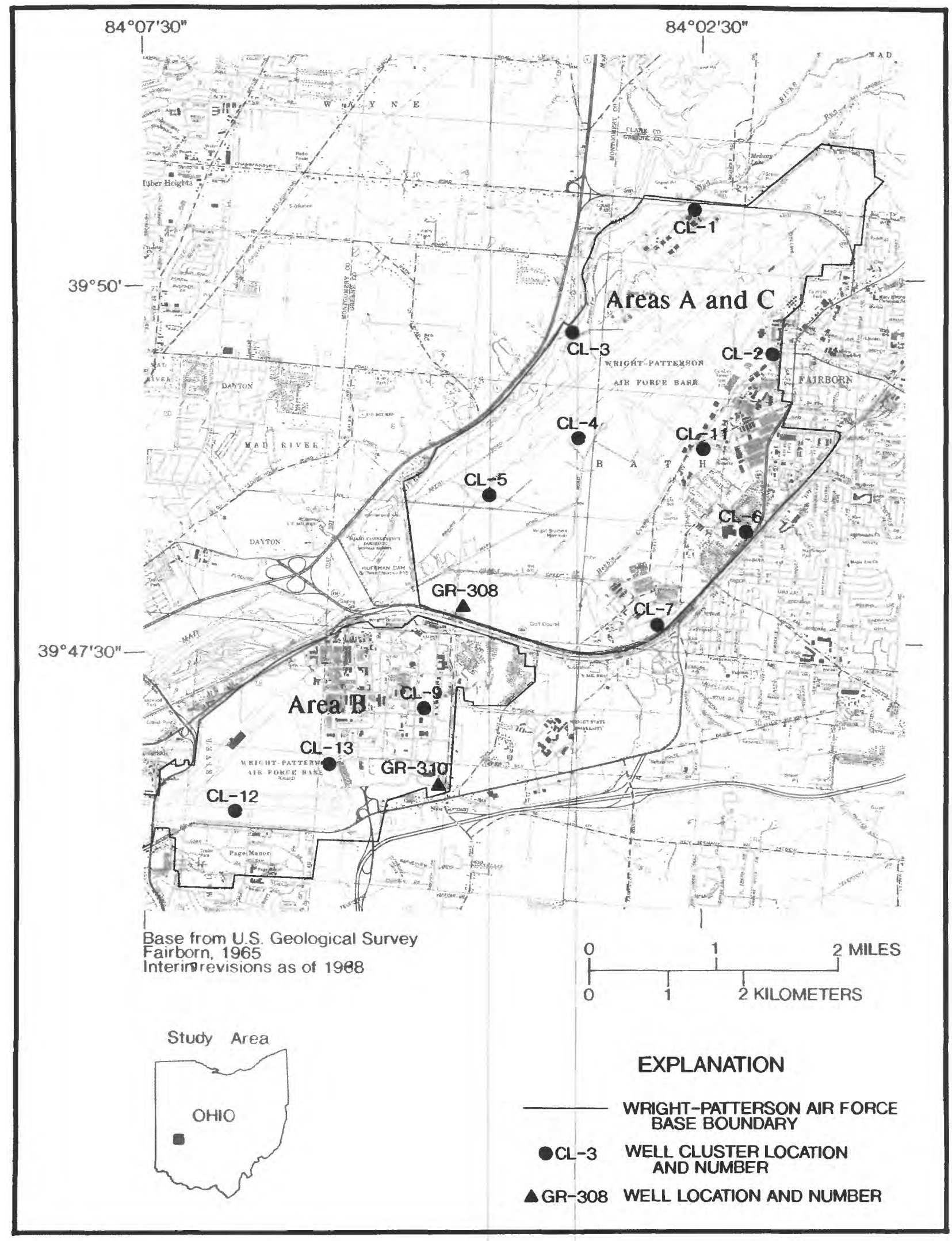

Figure 1.--Location of study area and well clusters. 


\section{ADDENDUM}

The purpose of this report is to present lithologic, natural-gamma, and well-construction data from these wells. No interpretation of the data is made.

\section{GEOLOGIC SETTING}

A buried bedrock valley, trending northeast-southwest, underlies Areas $A$ and $C$ of WPAFB. Depth to bedrock ranges from $5 \mathrm{ft}$ to more than $250 \mathrm{ft}$ in places. Areas $A$ and $C$ are in the flood plain of the Mad River. The western half of Area $B$ is also in the Mad River flood plain; depth to bedrock is generally more than $75 \mathrm{ft}$. The eastern half of Area $B$ is in an upland area, where bedrock is within $40 \mathrm{ft}$ of the land surface.

Most of the consolidated rocks (bedrock) underlying WPAFB consist of the Richmondian stage of Late Ordovician age (table 1). The rocks of the Richmondian stage are fossiliferous, interbedded shales and limestones. The shales are finegrained and soft; the limestone layers are dense and hard. The shale layers are as thick as $20 \mathrm{ft}$. The limestone beds consist of thin layers ranging from a few inches to $2 \mathrm{ft}$ thick (Walton and Scudder, 1960) and can form from 25 to 50 percent of the sequence. The rocks are greenish or blue gray; however, in the upper part of the Richmondian stage, noticeably reddish zones can be found. The upper part is exposed in a railroad cut at the southern end of the Huffman Dam (Norris and others, 1950).

The Brassfield Limestone of Early Silurian age is present above an altitude of about $920 \mathrm{ft}$ above sea level in Area $B$. The Brassfield Limestone is massive and evenly bedded near the base of the formation but forms thin and irregular beds near the top. At some locations, the base consists of a granular limestone. The Brassfield varies in color from dark gray to pink (Norris and others, 1950).

The regional dip of the rocks is northeastward; however, in the Fairborn area, the dip of the rocks is affected by a small fold approximately $5 \mathrm{mi}$ east of WPAFB. The rocks are nearly horizontal east of the base (Walton and Scudder, 1960).

Wisconsinan glacial deposits cover much of the bedrock in the WPAFB area. The deposits can be separated into till and stratified sand and gravel. The uplands are covered with till, which is an unsorted clay-rich mixture of sediments ranging in size from clay to boulders. The bedrock valleys are filled with outwash or valley-train deposits that are mostly sand and gravel. Lenses of till are present within the outwash in places (Walton and Scudder, 1960). Because outwash was deposited by meltwater streams, it consists mainly of sand and gravel; outwash deposits are typically well sorted. Generally, grain size of outwash can be variable horizontally and vertically (Flint, 1971). 


\section{ADDENDUM}

Table 1.--Generalized geologic section of the Wright-Patterson Air Force Base area (modified from Walton and Scudder, 1960)

\begin{tabular}{|c|c|c|c|c|}
\hline $\begin{array}{l}\text { System or } \\
\text { Period }\end{array}$ & $\begin{array}{l}\text { Series or } \\
\text { Epoch }\end{array}$ & $\begin{array}{l}\text { Group, forma- } \\
\text { tion, or stage }\end{array}$ & $\begin{array}{c}\text { Thickness } \\
\text { (Eeet) }\end{array}$ & $\begin{array}{l}\text { Character } \\
\text { of material }\end{array}$ \\
\hline \multirow{3}{*}{ Quaternary } & Holocene & & $5+$ & $\begin{array}{l}\text { Flood-plain deposits, } \\
\text { chiefly silt } \\
\text { and clay. }\end{array}$ \\
\hline & \multirow[t]{2}{*}{ Pleistocene } & $\begin{array}{l}\text { Wisconsinan } \\
\text { stage }\end{array}$ & $260+$ & $\begin{array}{l}\text { Outwash sand and } \\
\text { gravel; (deposited } \\
\text { as kames and valley } \\
\text { train by meltwaters } \\
\text { from the glacier) } \\
\text { and (or) } \\
\text { Till, a heterogeneous } \\
\text { mixture of clay, } \\
\text { sand, gravel, and } \\
\text { boulders in which } \\
\text { clay predominates; } \\
\text { (deposited directly } \\
\text { by the glacier). }\end{array}$ \\
\hline & & $\begin{array}{l}\text { Pre-Illinoian } \\
\text { stage }\end{array}$ & Unknown & $\begin{array}{l}\text { Sand and gravel or } \\
\text { till in the deepest } \\
\text { part of the buried } \\
\text { valleys beneath } \\
\text { the Wisconsinan } \\
\text { deposits. }\end{array}$ \\
\hline \multirow{2}{*}{ Silurian } & $\begin{array}{l}\text { Middle } \\
\text { Silurian }\end{array}$ & $\begin{array}{l}\text { Dayton } \\
\text { Limestone }\end{array}$ & $2+$ & $\begin{array}{l}\text { A white or bluish } \\
\text { fine-grained thin- } \\
\text { bedded dense lime- } \\
\text { stone or dolomite. }\end{array}$ \\
\hline & $\begin{array}{l}\text { Lower } \\
\text { (or Early) } \\
\text { Silurian }\end{array}$ & $\begin{array}{l}\text { Brassfield } \\
\text { Limestone }\end{array}$ & $30+$ & $\begin{array}{l}\text { Limestone in layers } \\
\text { ranging from thick } \\
\text { and massive layers } \\
\text { near the base to } \\
\text { thin near the top. }\end{array}$ \\
\hline Ordovician & $\begin{array}{l}\text { Upper } \\
\text { (or Late) } \\
\text { Ordovician }\end{array}$ & $\begin{array}{l}\text { Richmondian, } \\
\text { Mayvillian, } \\
\text { and Edenian } \\
\text { stages, } \\
\text { undivided }\end{array}$ & $1,000+$ & $\begin{array}{l}\text { Shale, soft, } \\
\text { calcareous, inter- } \\
\text { bedded with thin } \\
\text { layers of hard } \\
\text { limestone. }\end{array}$ \\
\hline
\end{tabular}




\section{METHODS OF WELL CONSTRUCTION AND GEOLOGIC SAMPLING}

The wells were installed in three phases. During the first phase, 14 bedrock wells were drilled by the cable-tool method until bedrock was reached. Split-spoon samples of the unconsolidated materials were collected at 5-ft intervals during the drilling. The samples were used to determine the character of the geologic material penetrated during drilling. Four shelbytube samples were collected from clay-rich units and analyzed by use of a triaxial chamber permeameter to determine the permeability of the clay (table 2). The bedrock part of the hole was drilled by rotary coring. Three-inch-diameter cores $20 \mathrm{ft}$ in length were collected for each bedrock well.

The second phase of drilling consisted of installation of 12 wells in the unconsolidated sediments at 6 sites; installation of these wells completed 6 clusters. The wells were drilled by use of an air-rotary rig equipped with a casing hammer. During the third phase of drilling, the final four well clusters were completed with the installation of nine wells by the cable-tool method.

During the second and third phases, double- or triplecased holes were drilled in the unconsolidated deposits where clay layers were between the surface and the desired well depth. No geologic samples were collected during the second and third phases of drilling.

A total of 35 wells at 13 locations were drilled. Ten clusters consist of wells completed in bedrock and in unconsolidated sediments. One cluster consists of two wells completed in bedrock. At the remaining two locations, a single well was completed in bedrock.

All of the wells were constructed by use of a drive casing larger than the final well casing. When the desired depth was reached, the final well casing was installed through the drive casing, which was then pulled back, and the annulus was grouted to the land surface. Bentonite grout was used in the saturated zone, and cement-bentonite grout (usually a 20:1 mixture) was used in the unsaturated zone and between the larger drive casings of the double- and triple-cased holes.

All but three of the bedrock wells were screened rather than finishing them with an open interval below the bottom of the casing. The annular space around the screens was packed with clean silica sand. At most of the wells completed in unconsolidated materials, the formation in the screened zone was relatively free of clay. In construction of these wells, the drive casing was pulled back to allow the native formation to collapse around the screen and create a natural gravel pack; however, if the formation contained very fine sand, silt, and (or) clay, the screen 
Table 2.--Permeability of selected sediment samples analyzed by use of a triaxial chamber permeameter

[ft, feet; $1 \mathrm{~b} / \mathrm{in}^{2}$, pounds per square inch; $\mathrm{ft} / \mathrm{s}$, feet per second; $1 \mathrm{~b} / \mathrm{ft}^{3}$, pounds per cubic foot]

Sample ${ }^{1}$ Confining ${ }^{2}$ Head $^{3}$

depth

(ft) pressure

$\left(1 \mathrm{~b} / \mathrm{in}^{2}\right)$ pressure Permeability

$\left(1 \mathrm{~b} / \mathrm{in}^{2}\right)$
Sample

$(\mathrm{ft} / \mathrm{s})$ classification
GR-314

(clus-

ter 2)

$65.5-67.5 \quad 100$

100

$65.5-67.5$

GR-307

(clus-

ter 7)

$65.0-67.2 \quad 100$

100

GR-3II

(clus-

$41.3-43$

ter 11)

50

$0 \quad 1.6 \times 10^{-9}$

Gray silty clay, trace of medium sand. Dry density, $117.7 \mathrm{lb} / \mathrm{ft}^{3}$. Moisture content, 16.9 percent.

32

$8.9 \times 10^{-11}$

Gray sandy clay, with little gravel and silt. Dry density, $142.6 \mathrm{lb} / \mathrm{ft}^{3}$. Moisture content, 6.5 percent.

Gray sandy clay, trace of silt and seams of fine to medium sand. Dry density, $131.3 \mathrm{lb} / \mathrm{ft}^{3}$. Moisture content, 10.7 percent.

Dark-gray, silty clay, fine sandy silt lenses. Dry density, $112.5 \mathrm{lb} / \mathrm{ft}^{3}$. Moisture content, 14.3 percent.

75

$4.3 \times 10^{-10}$

MT-133

$145-147$

100

ter 12) 
was packed with clean silica sand before the drive casing was pulled back. A granular bentonite seal was placed above all sand packs to prevent infiltration of the grout into the screened interval. All of the screens were sealed on the bottom with a welded or threaded cap.

The bedrock wells were constructed with black steel waterwell casing. The remainder of the wells were constructed with stainless-steel casing. Stainless-steel casing was used to avoid problems with future water-quality sampling plans. The screens in all of the wells are constructed of stainless steel.

\section{LITHOLOGIC, NATURAL-GAMMA, GRAIN-SIZE, AND WELL-CONSTRUCTION DATA}

Lithologic and natural-gamma logs, grain-size data from selected split-spoon samples, and details on well construction are presented in figures 2 through 68 and in table 3 . The data are organized by cluster; for example, figures 2 through 8 contain data on the wells in cluster 1.

The lithologic log for each cluster (for example, cluster I, fig. 2) consists of a graphical representation and a written description of the lithology. Each log is a compilation of the drillers' and on-site geologists' records.

The natural-gamma and lithologic logs were obtained for the deepest well in each cluster and are considered to be representative of other wells in that cluster (for example, cluster 1, fig. 2). The natural-gamma log is typically a continuous vertical profile of the borehole made during the steady movement of the probe along the length of the borehole. The probe measures natural-gamma-ray activity per unit volume of rocks and sediments. Natural-gamma-ray activity generally depends on the activity of naturally occurring isotopes of potassium-40, uranium-238, and thorium-232. These naturally occurring radioisotopes are more prevalent in clay-bearing formations than in other formations; generally, the naturalgamma log responds to clay-rich formations (Alger and Harrison, 1989). Natural-gamma logs were collected after the wells were constructed and grouted. The bentonite (clay) plug and grout emplaced in the annular space can affect the logs, but the degree to which the logs are affected is difficult to determine. The natural-gamma log provides data that supplement the lithologic data collected by the on-site geologist.

Grain-size distributions from selected split-spoon samples (for example, figs. 3, 4, and 5) were obtained by sieve analyses of the samples. The analyses were performed by placing a sediment sample of known weight on top of a series of sieves. The mesh sizes of the sieves decrease from top to bottom. The sieves are shaken for a period of time, and the sample separates into portions of uniform grain size. The weight of the sample 
retained by each sieve is converted to a percentage of the total sample weight. The data are then graphed as "percentage coarser, by weight" as a function of grain size.

Details of the final construction for each well are shown in diagrams (for example, figs. 6, 7, and 8). The total depth, screen length, and grouting details are shown. The water level shown on the diagrams was measured on February 21, 1991. Repetitive water-level measurements have revealed that water levels in three bedrock wells, GR-311, GR-312, and GR-315, have not yet stabilized. These construction details also are listed in table 3 . 


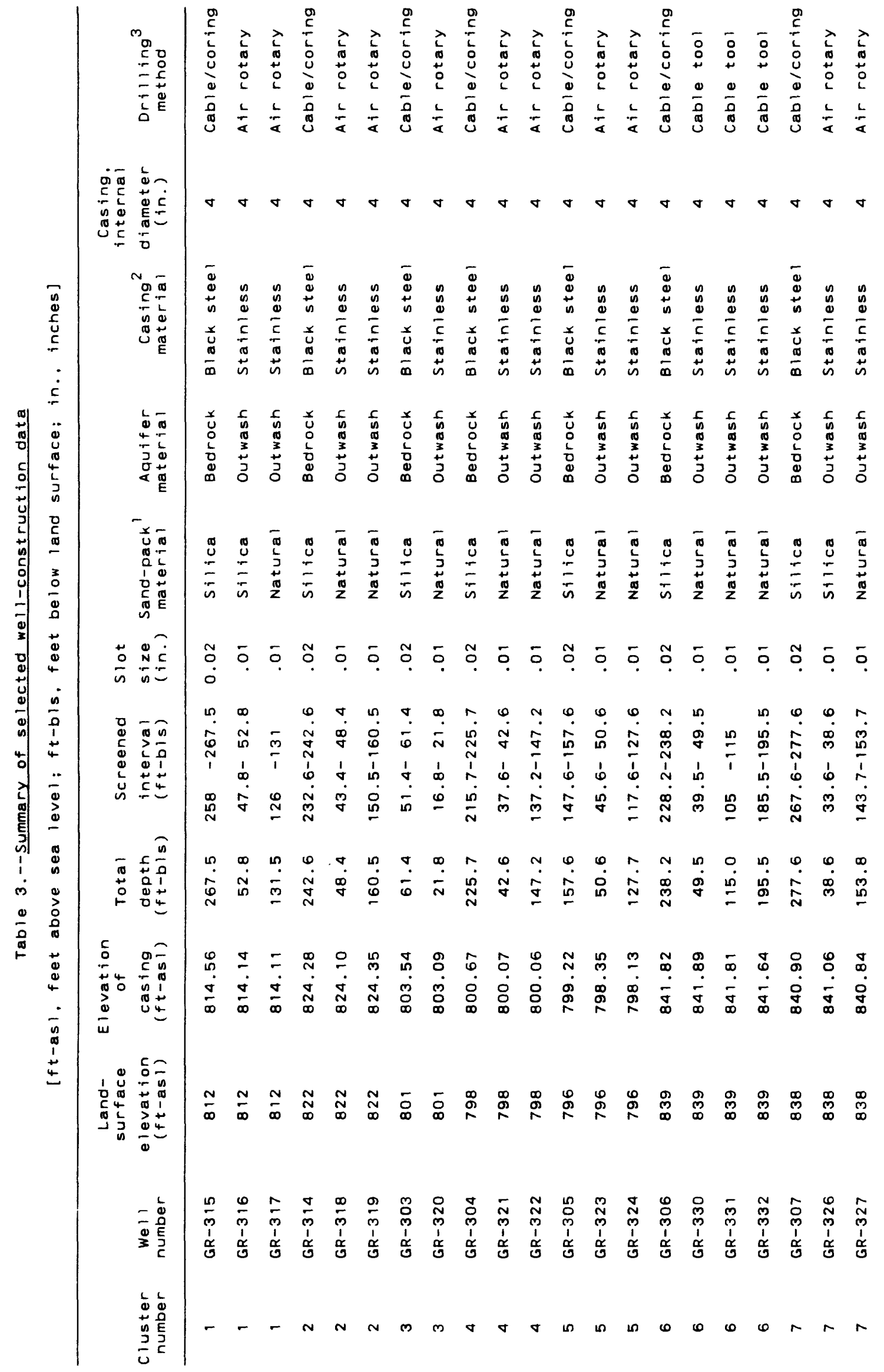




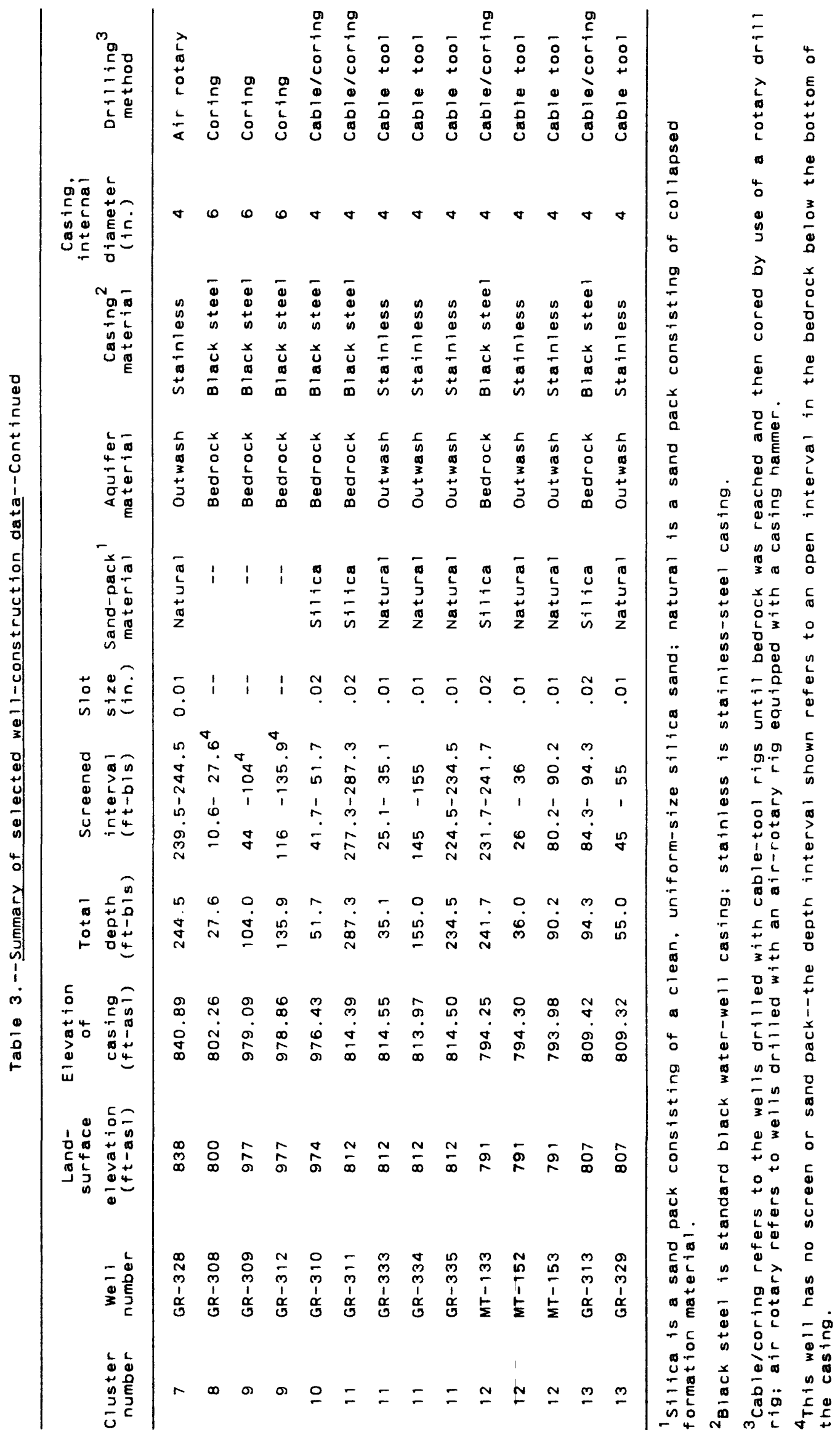




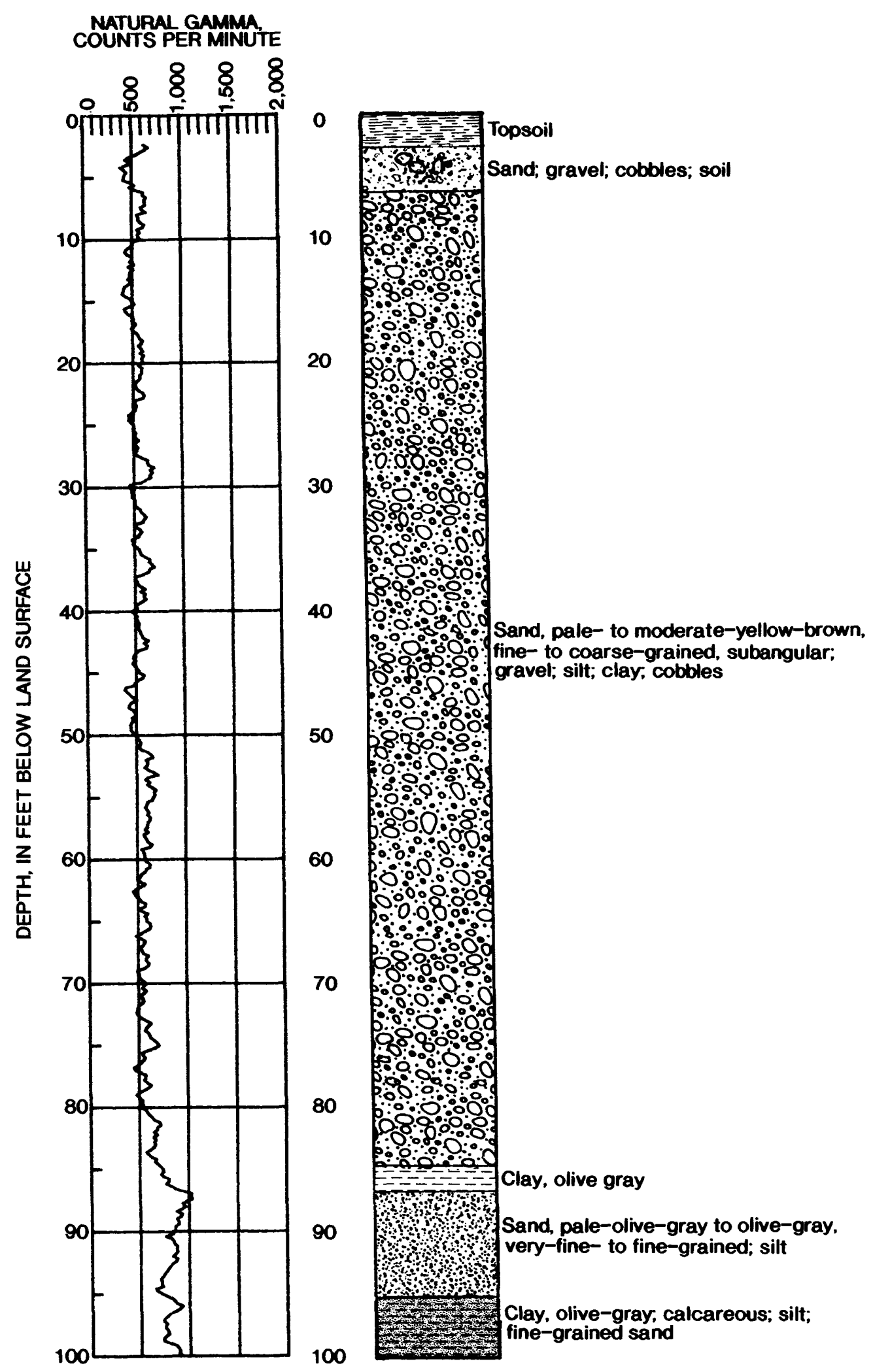

Figure 2.--Natural-gamma and lithologic logs for well GR-315 (cluster 1). 


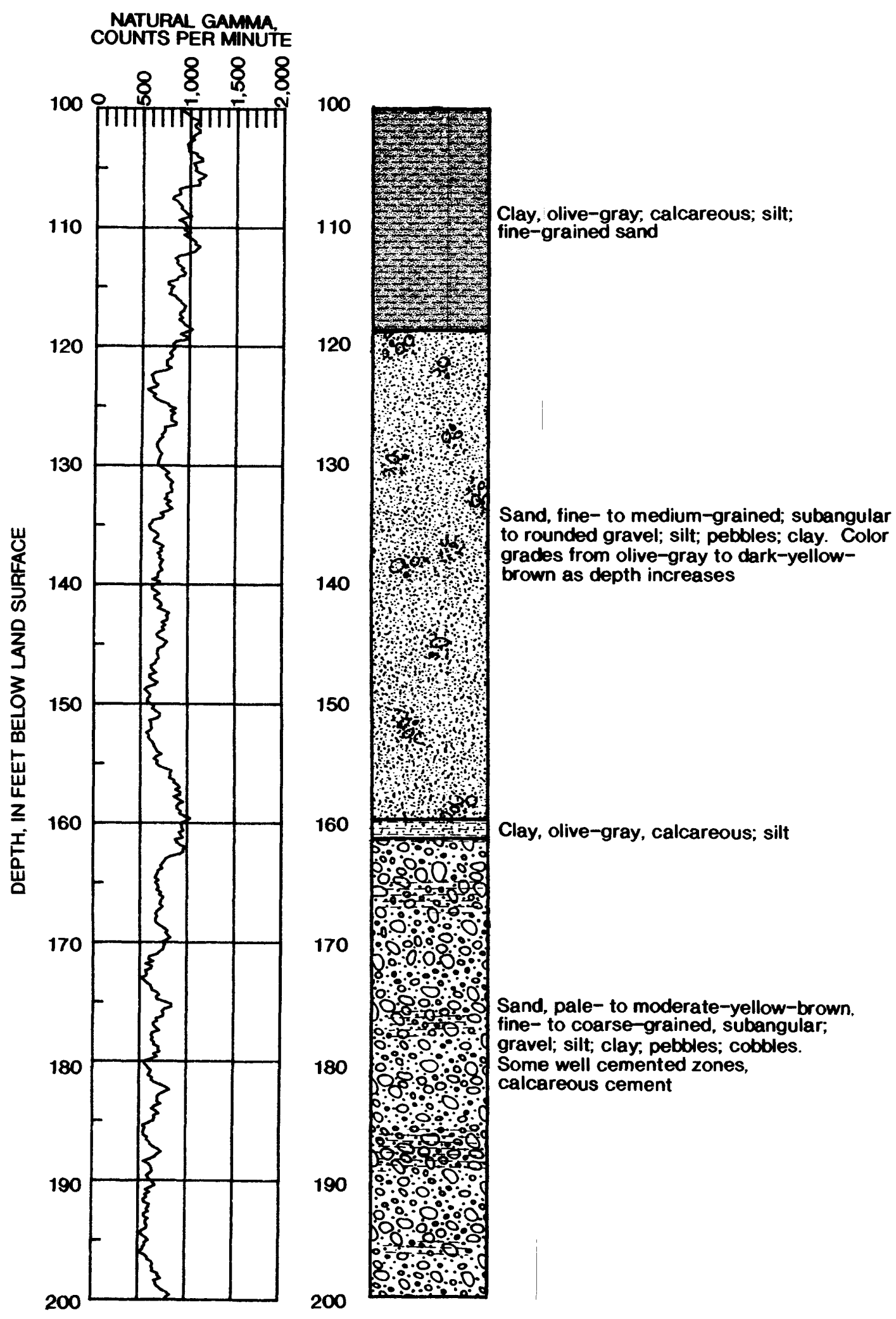

Figure 2.--Natural-gamma and lithologic logs for well GR-315 (cluster 1)--Continued. 

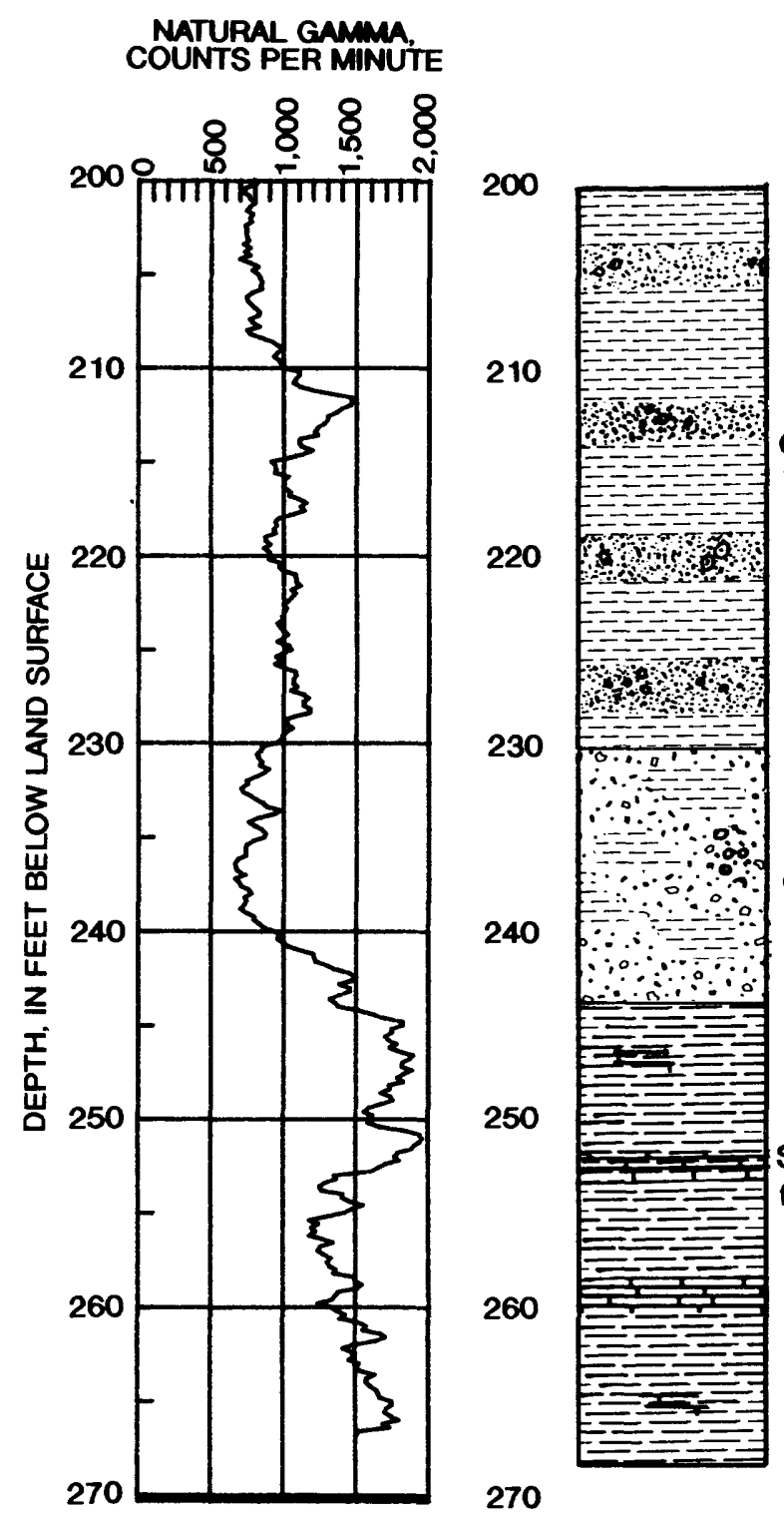

Clay, olive-gray, calcareous; stringers of fineto medium-grained silty sand and gravel

240

and; angular gravel; pebbles; olive gray clay. calcareous

250
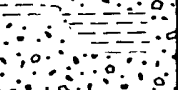

$\because \because \because \because 30$

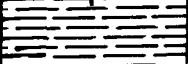

Shale, greenish-gray, fissile, with blue-gray fossiliferous limestone intercasts and interbeds

260

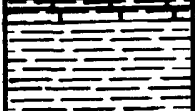

270

Figure 2.--Natural-gamma and lithologic logs for well GR-315 (cluster 1)--Continued. 


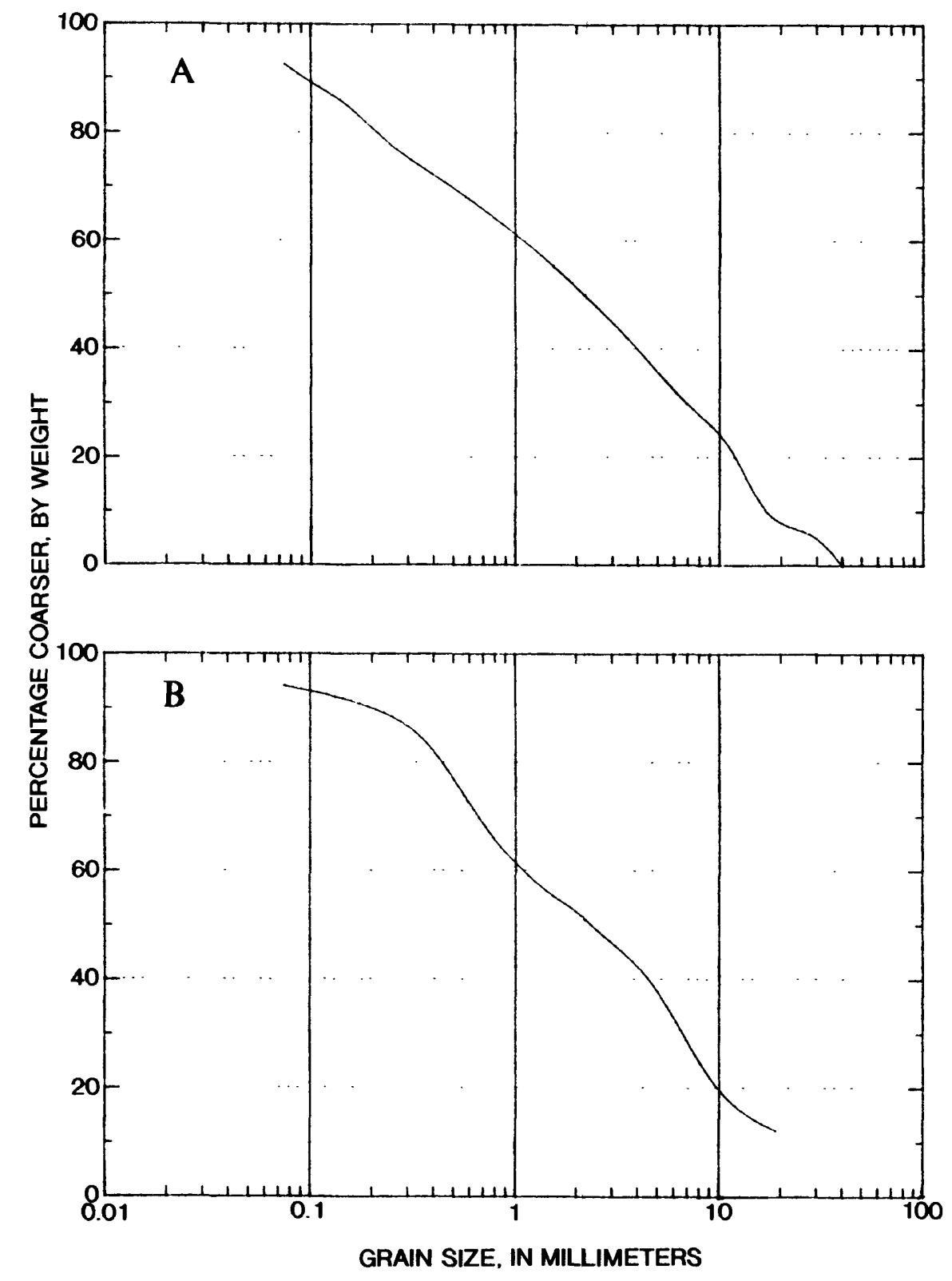

Figure 3.--Grain-size distributions of sediment samples from well GR-315 (cluster 1) (A) 30 to 32 feet and (B) 50.4 to 52.4 feet. 


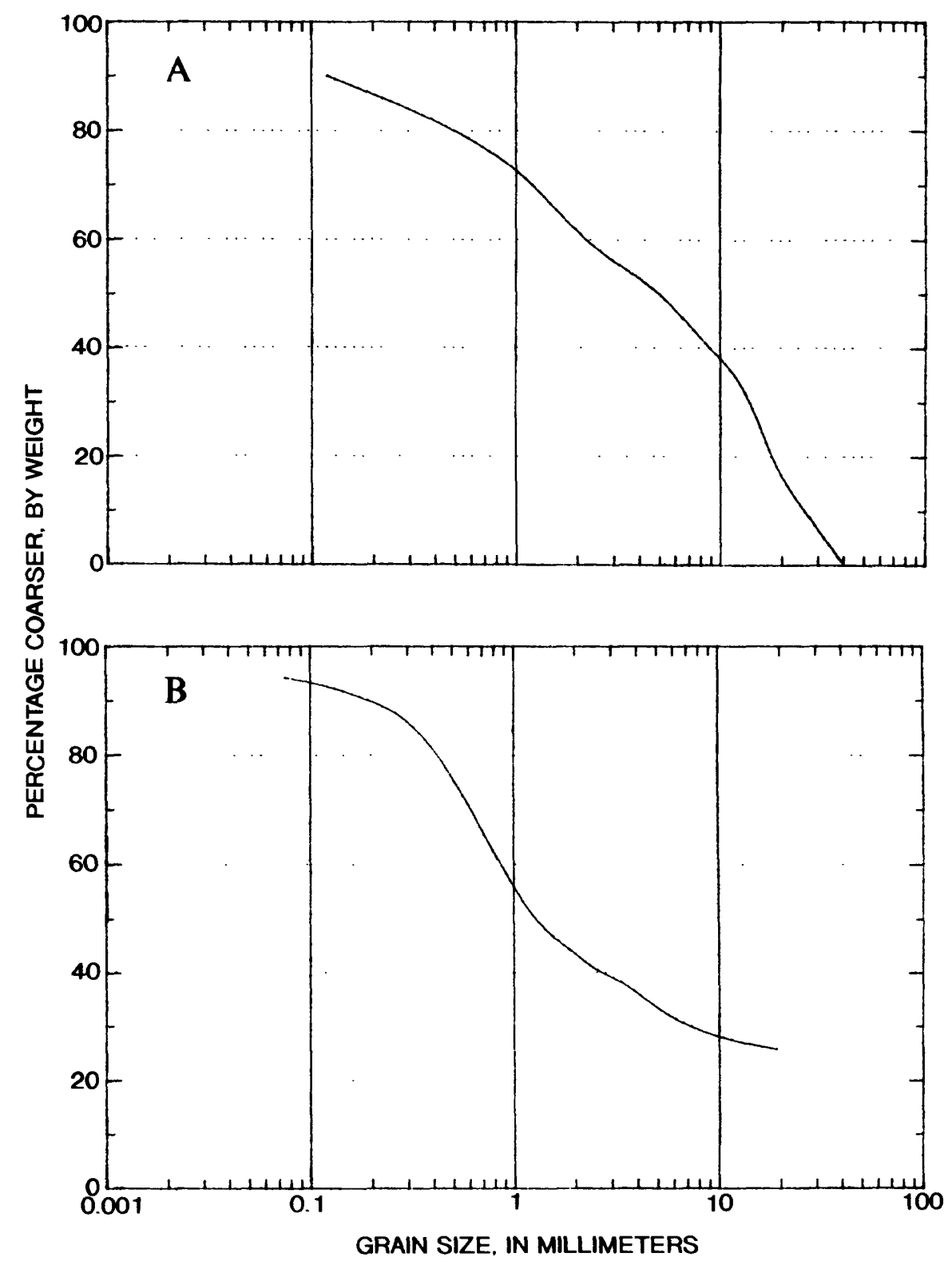

Figure 4.--Grain-size distributions of sediment samples from well GR-315 (cluster 1) (A) 76.2 to 78.2 feet and (B) 143.3 to 145.3 feet. 


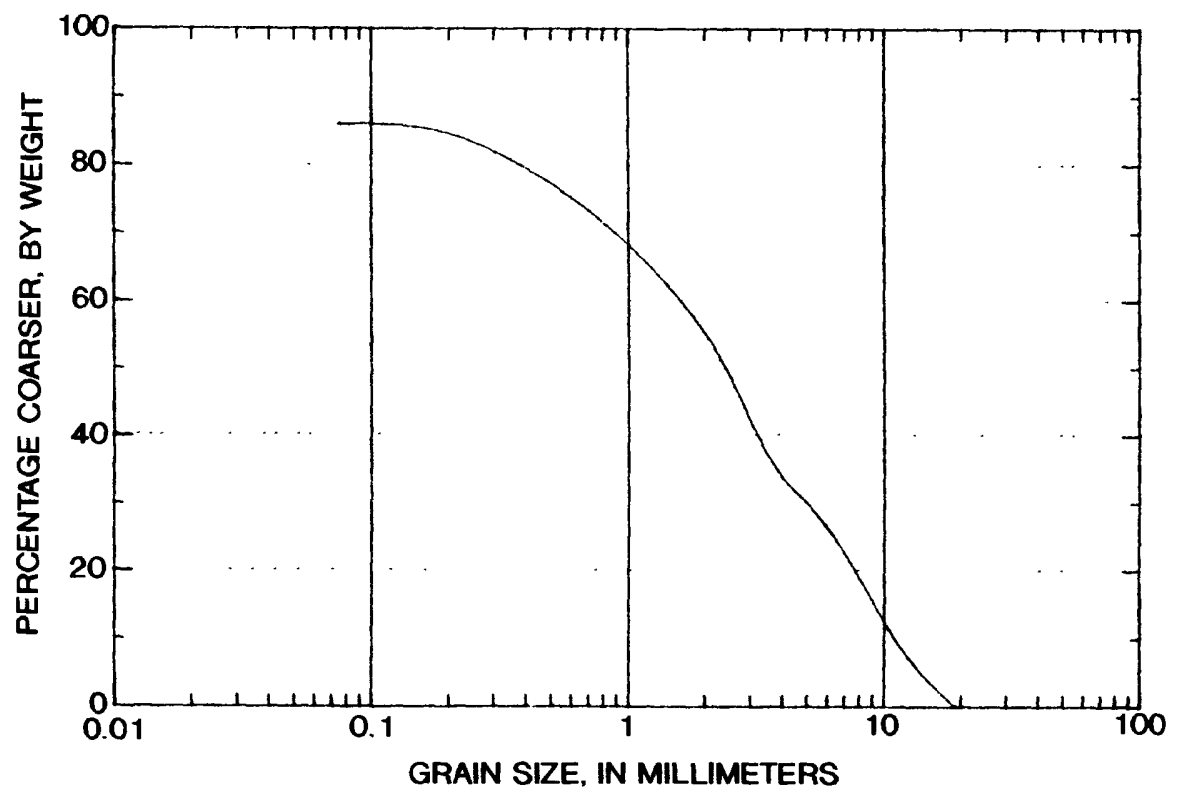

Figure 5.--Grain-size distributions of sediment samples from well GR-315 (cluster 1) 149.7 to 151.7 feet. 


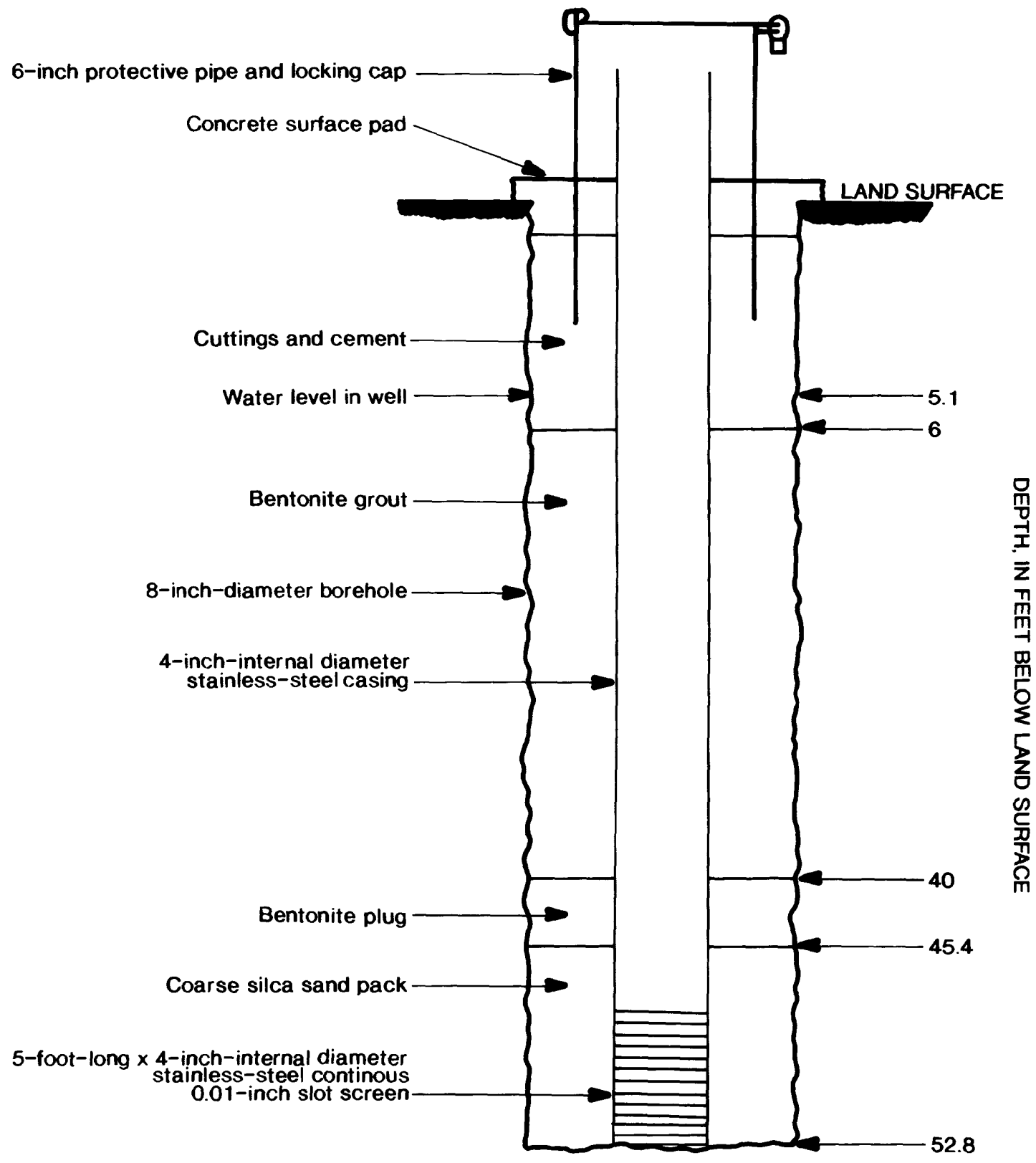

Not to scale

Figure 6.--Construction diagram for well GR-316. 


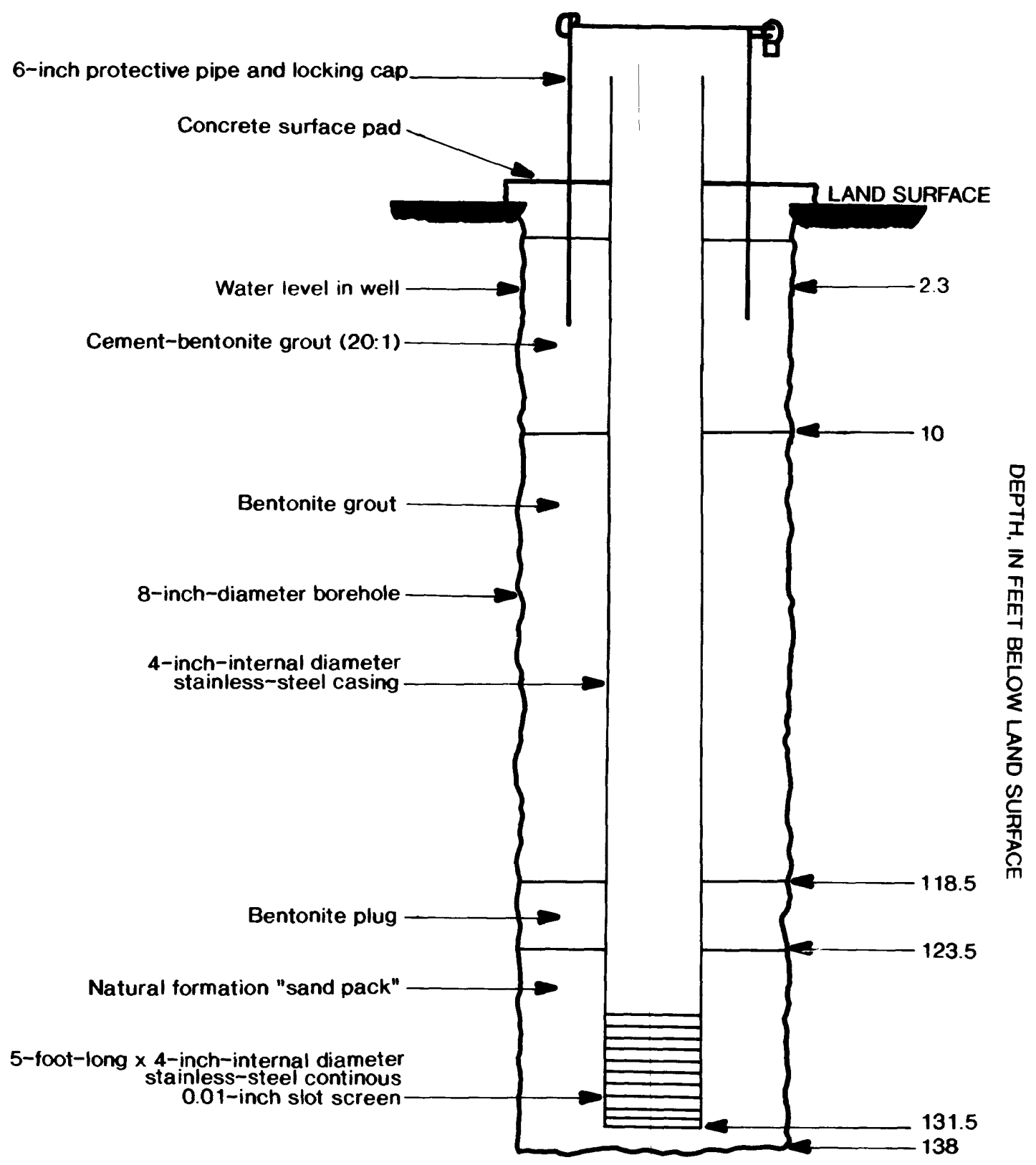

Figure 7.--Construction diagram for well GR-317 


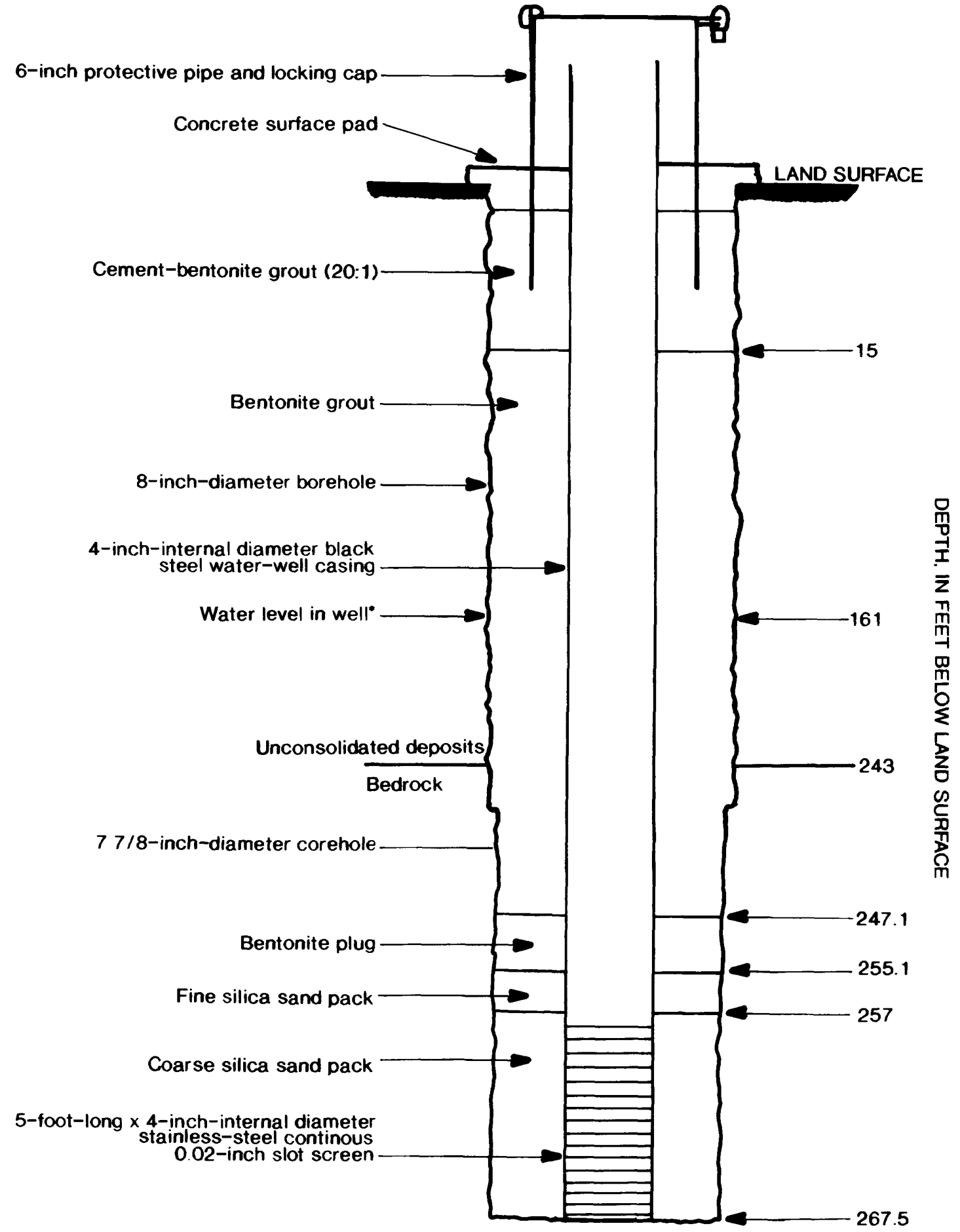

Figure 8.--Construction diagram for well GR-315 


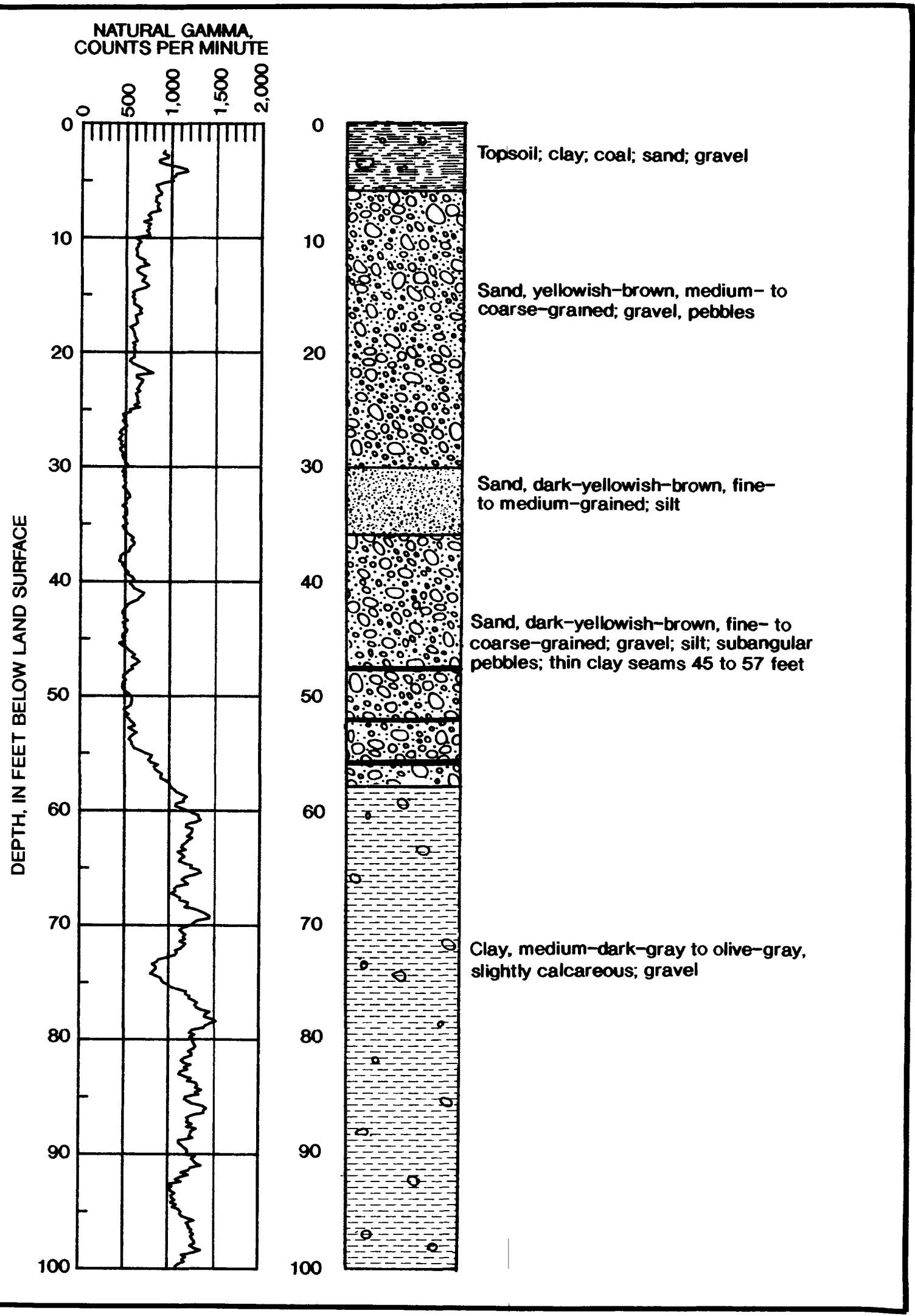

Figure 9.--Natural-gamma and lithologic logs for well GR-314 (cluster 2). 


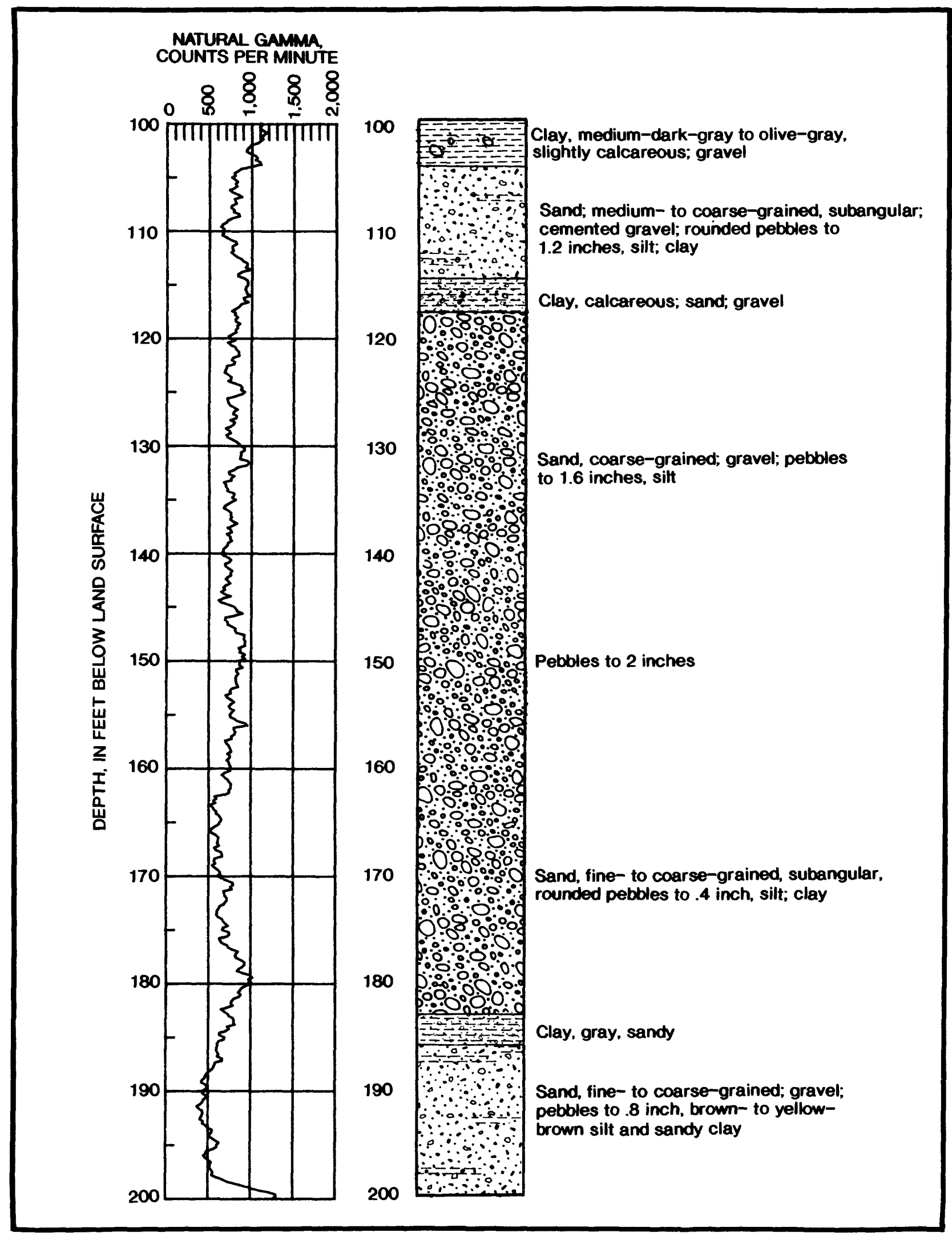

Figure 9.--Natural-gamma and lithologic logs for well GR-314 (cluster 2)--Continued. 


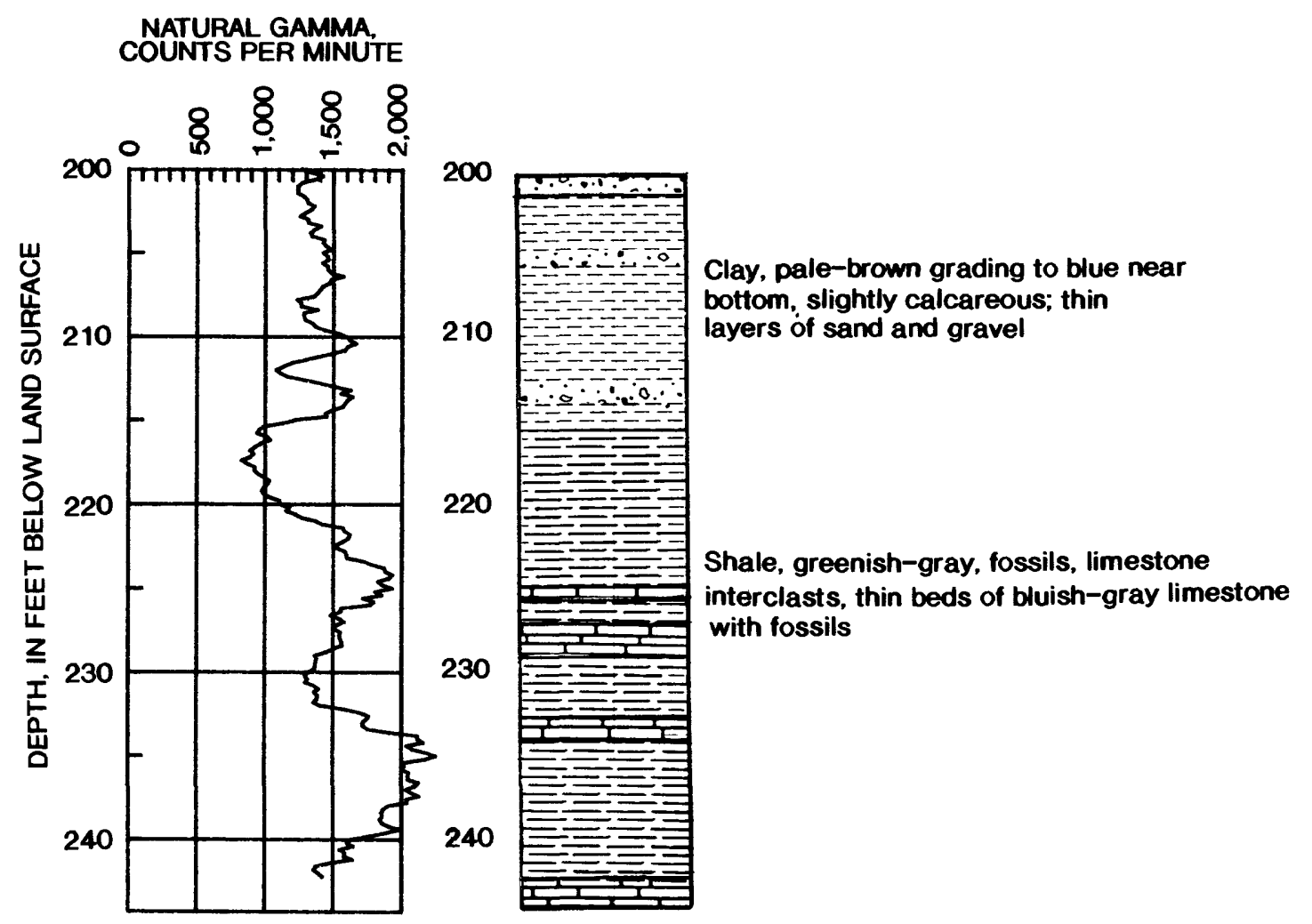

Figure 9.--Natural-gamma and lithologic logs for well GR-314 (cluster 2)--Continued. 


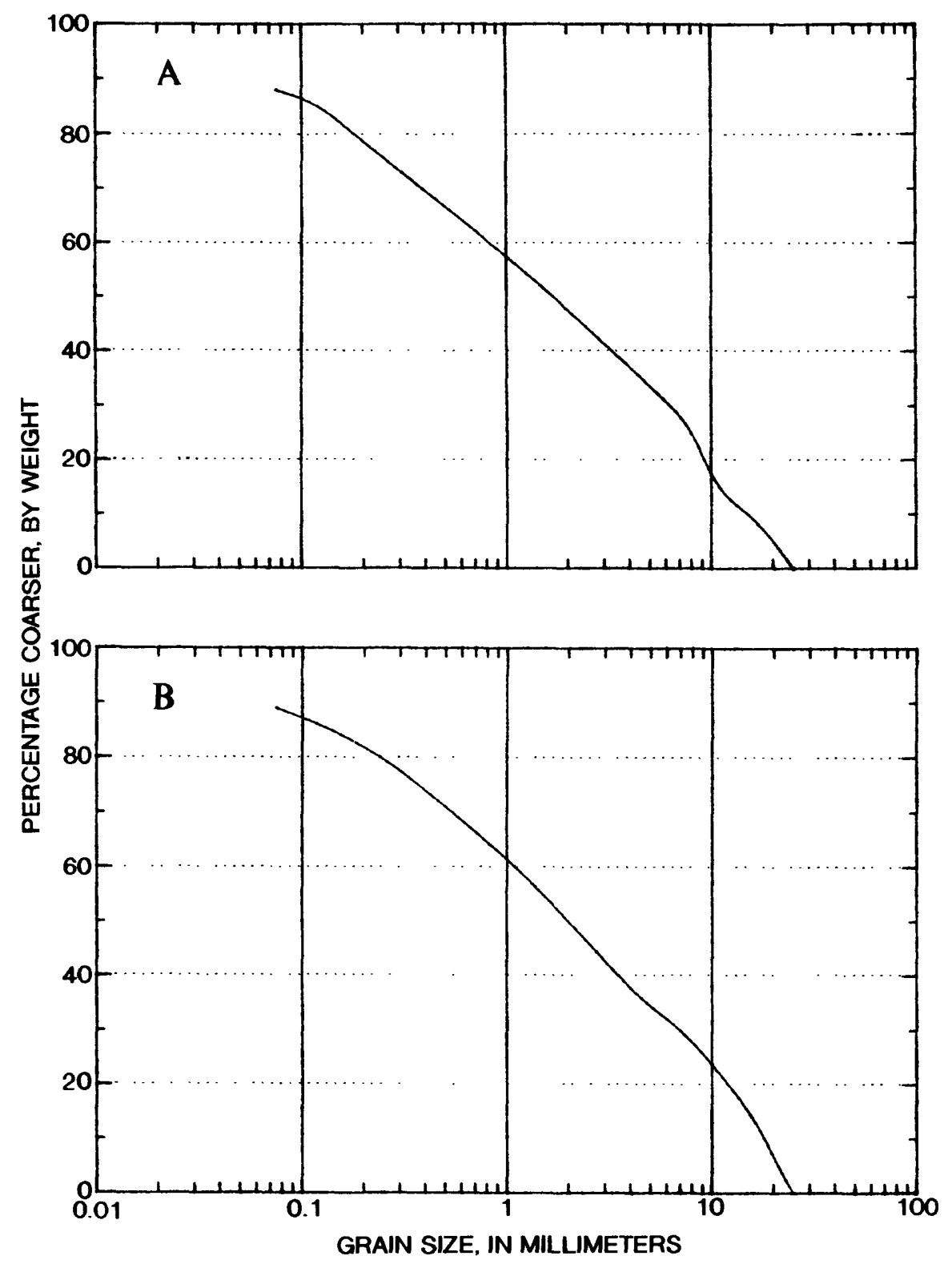

Figure 10.--Grain-size distributions of sediment samples from well GR-314 (cluster 2) (A) $\mathbf{4 4 . 8}$ to 46.8 feet and (B) 50.2 to 52.2 feet. 


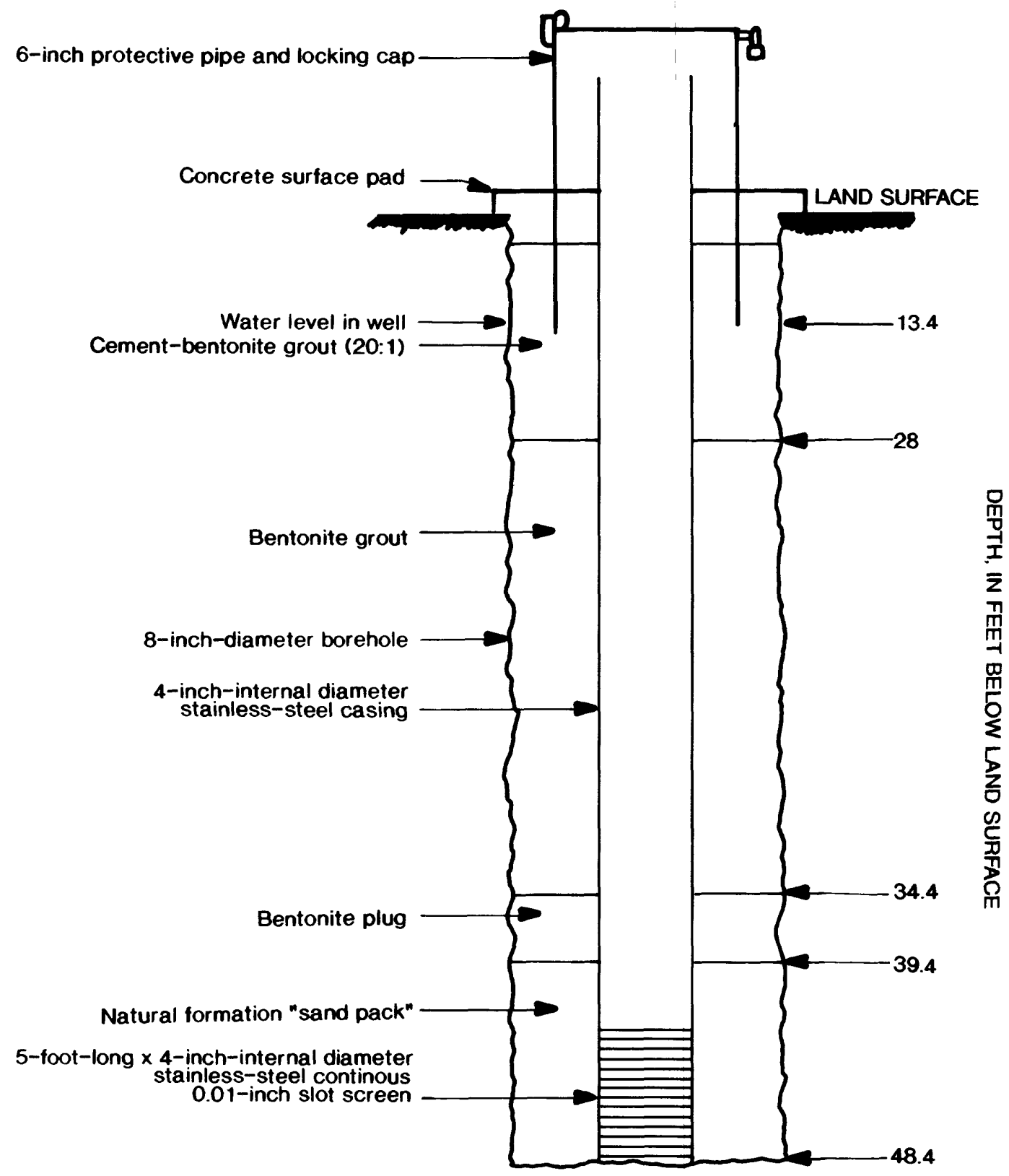

Figure 11.--Construction diagram for well GR-318 


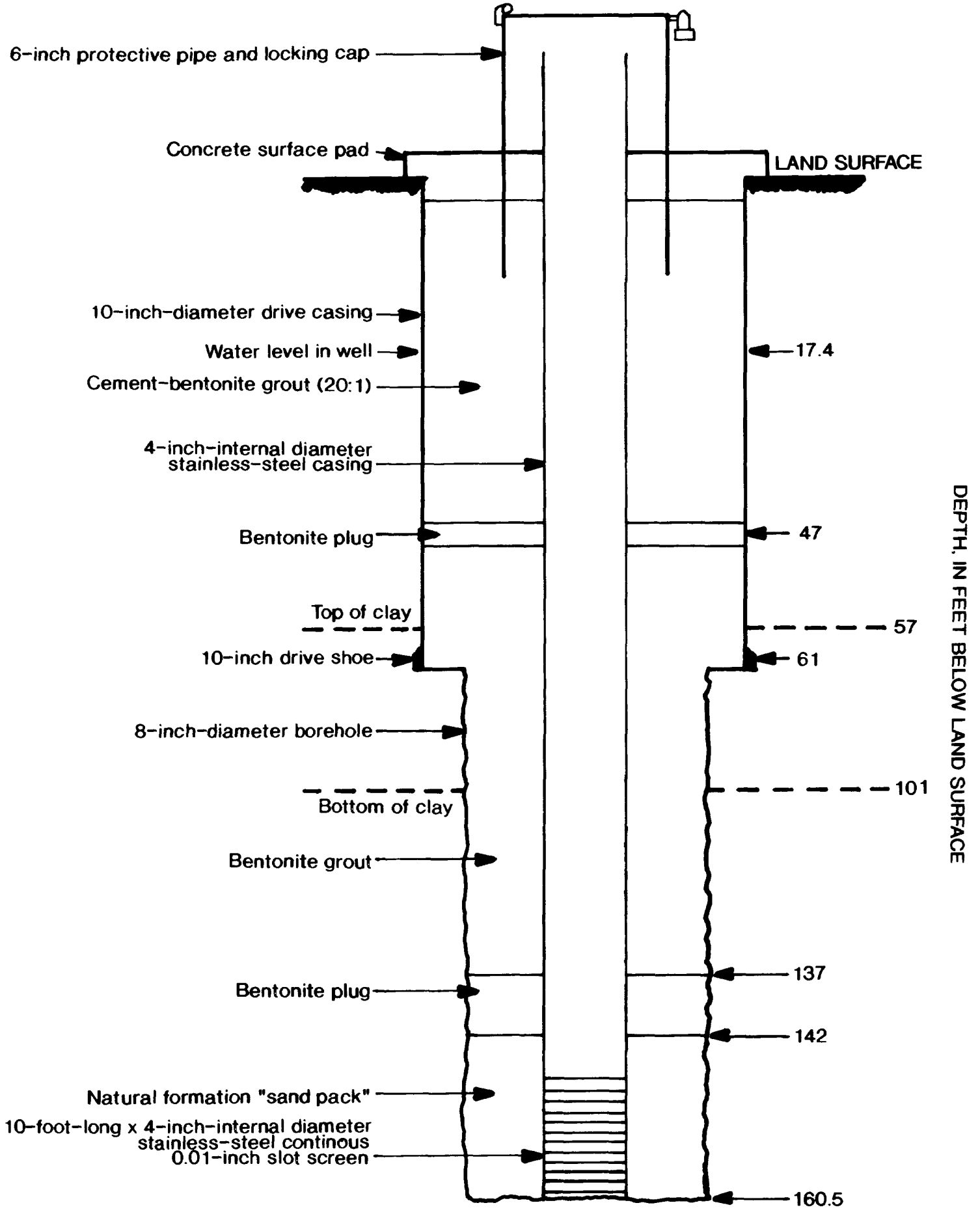

Not to scale

Figure 12.--Construction diagram for well GR-319. 


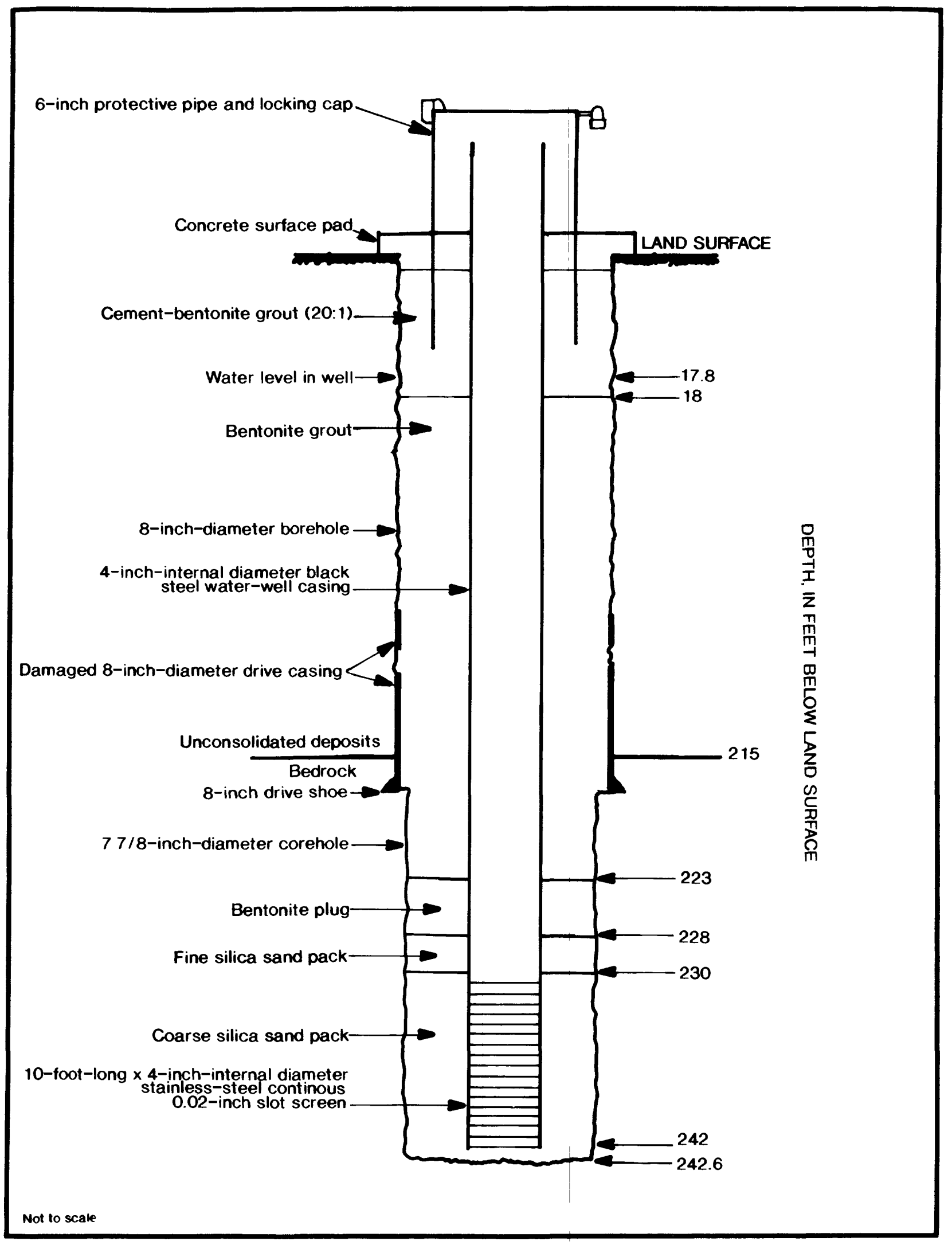

Figure 13.--Construction diagram for well GR-314. 


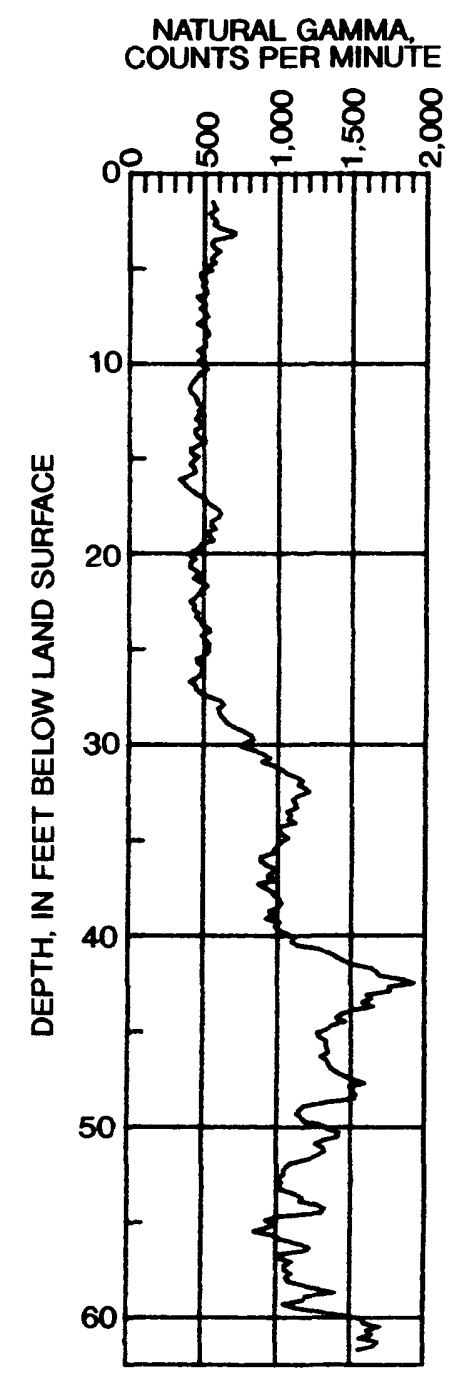

0

10

20

30

40

50

60

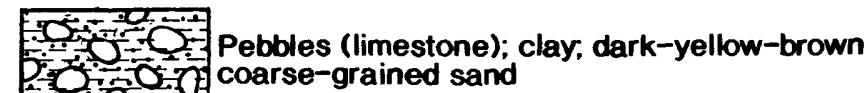
coarse-grained sand

Sand, pale- to dark-yellow-brown, fine- to medium-grained; subrounded gravel; pebbles

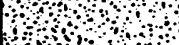

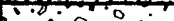

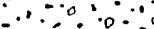

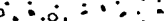

Sand dark-yellow-brown coarse- to very coarse-grained, subangular; silt; clay

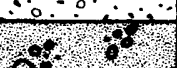

8

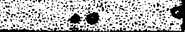

Silt, dark-yellow-brown, pebbles

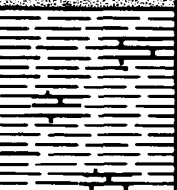

Shale, gray-green, fossils; blue-gray fossiliferous limestone

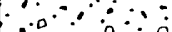

Figure 14.--Natural-gamma and lithologic logs for well GR-303 (cluster 3). 


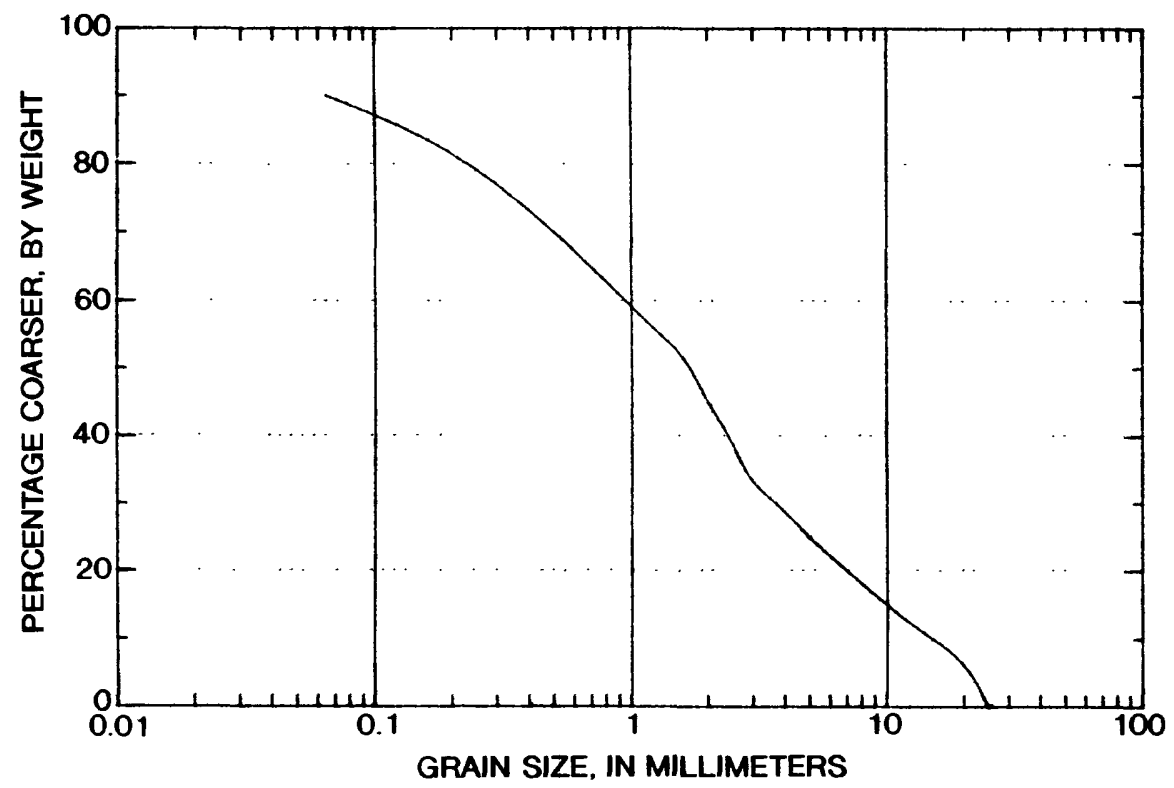

Figure 15.--Grain-size distributions of sediment samples from well GR-303 (cluster 3) 20.1 to 22.1 feet. 


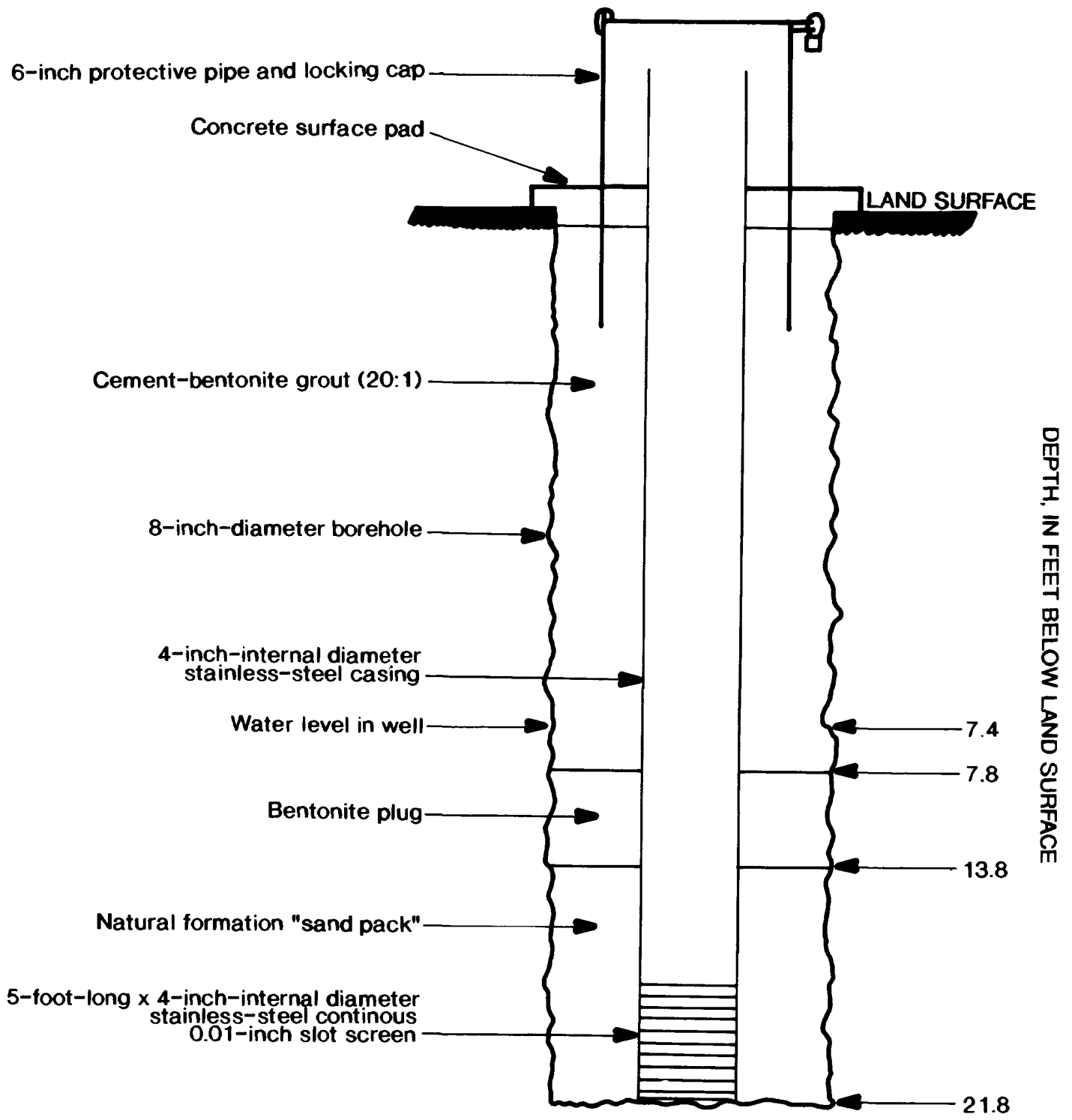

Figure 16.--Construction diagram for well GR-320. 


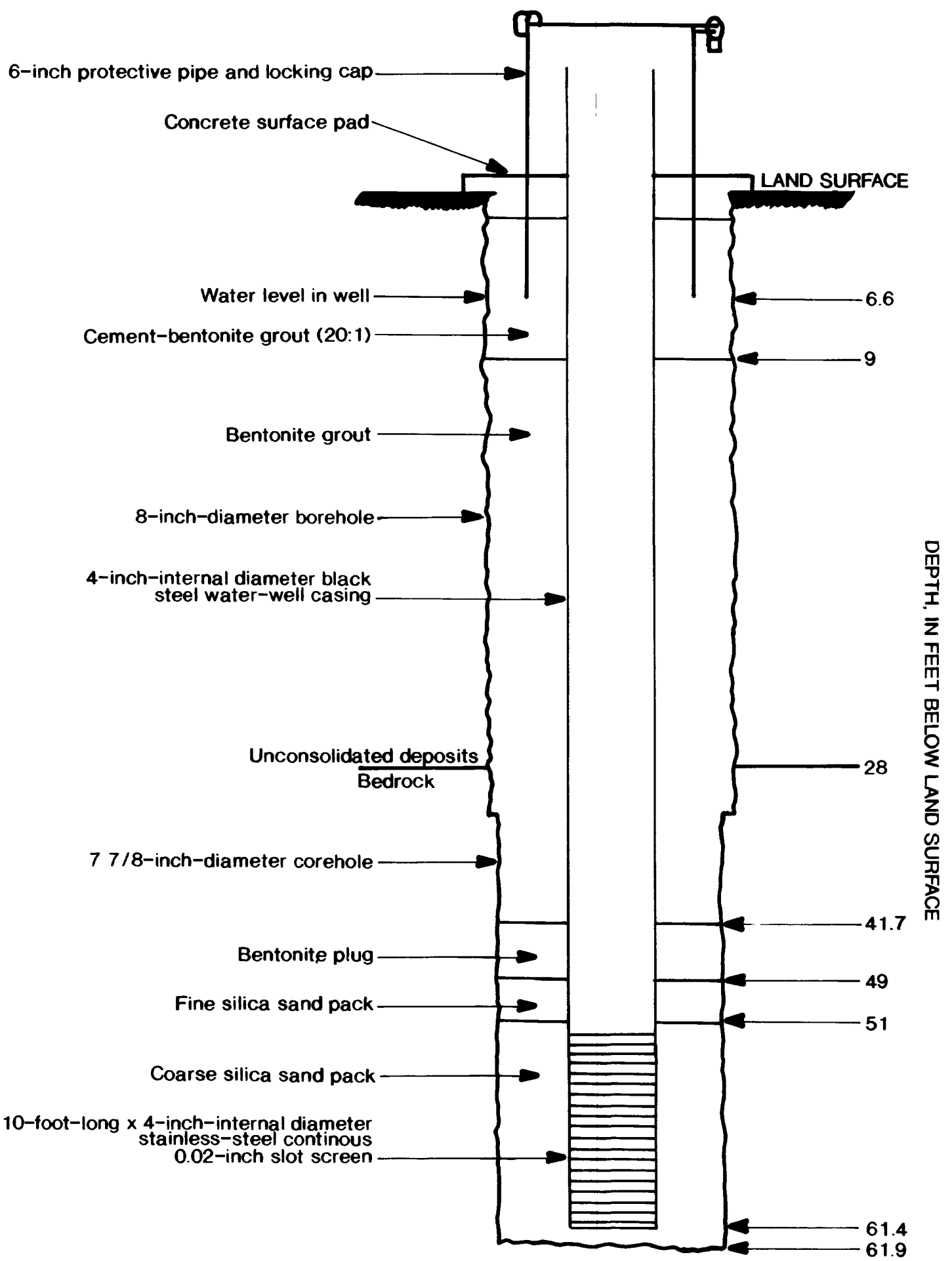

Not to scale

Figure 17.--Construction diagram for well GR-303. 


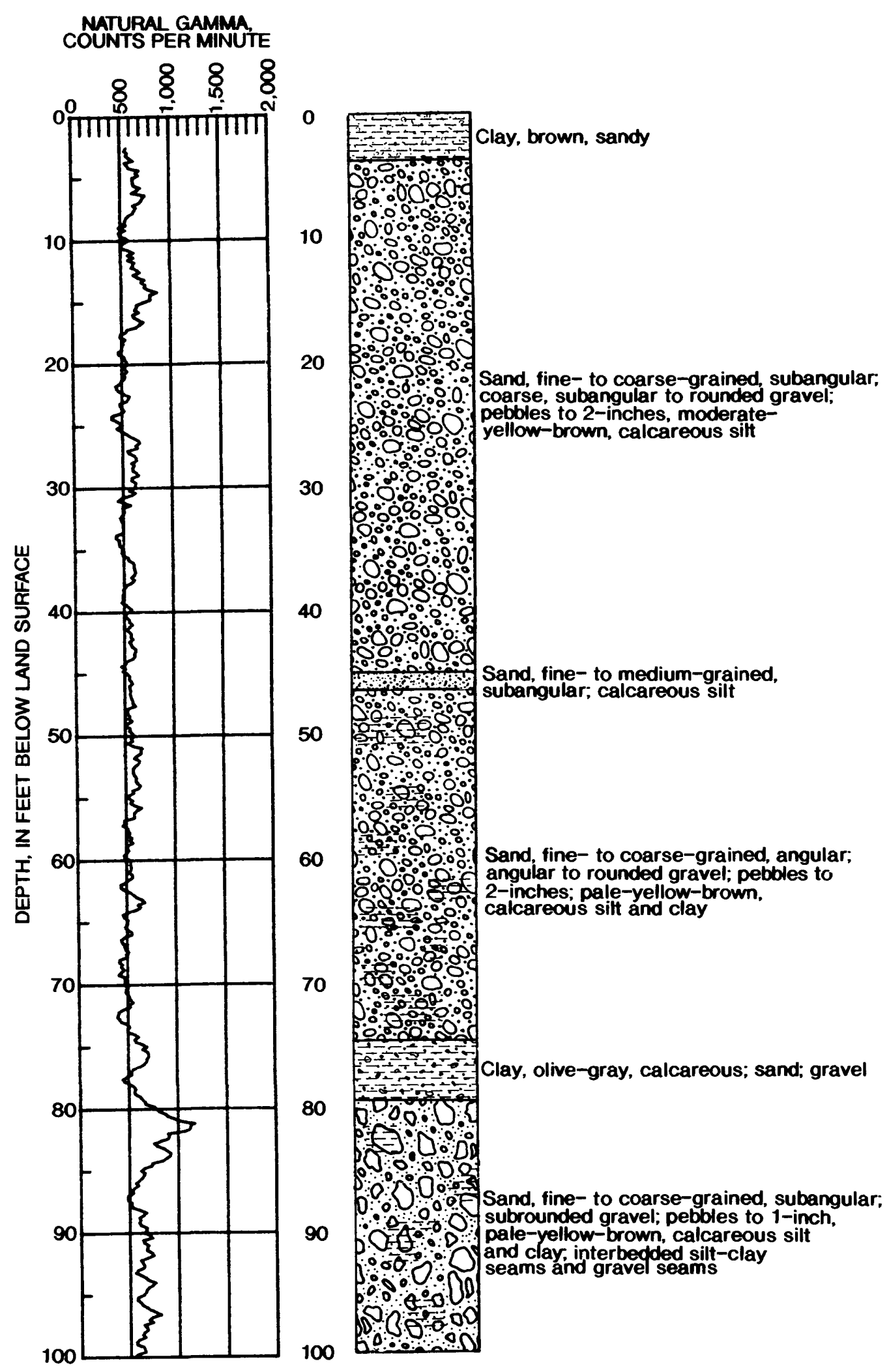

Figure 18.--Natural-gamma and lithologic logs for well GR-304 (cluster 4). 


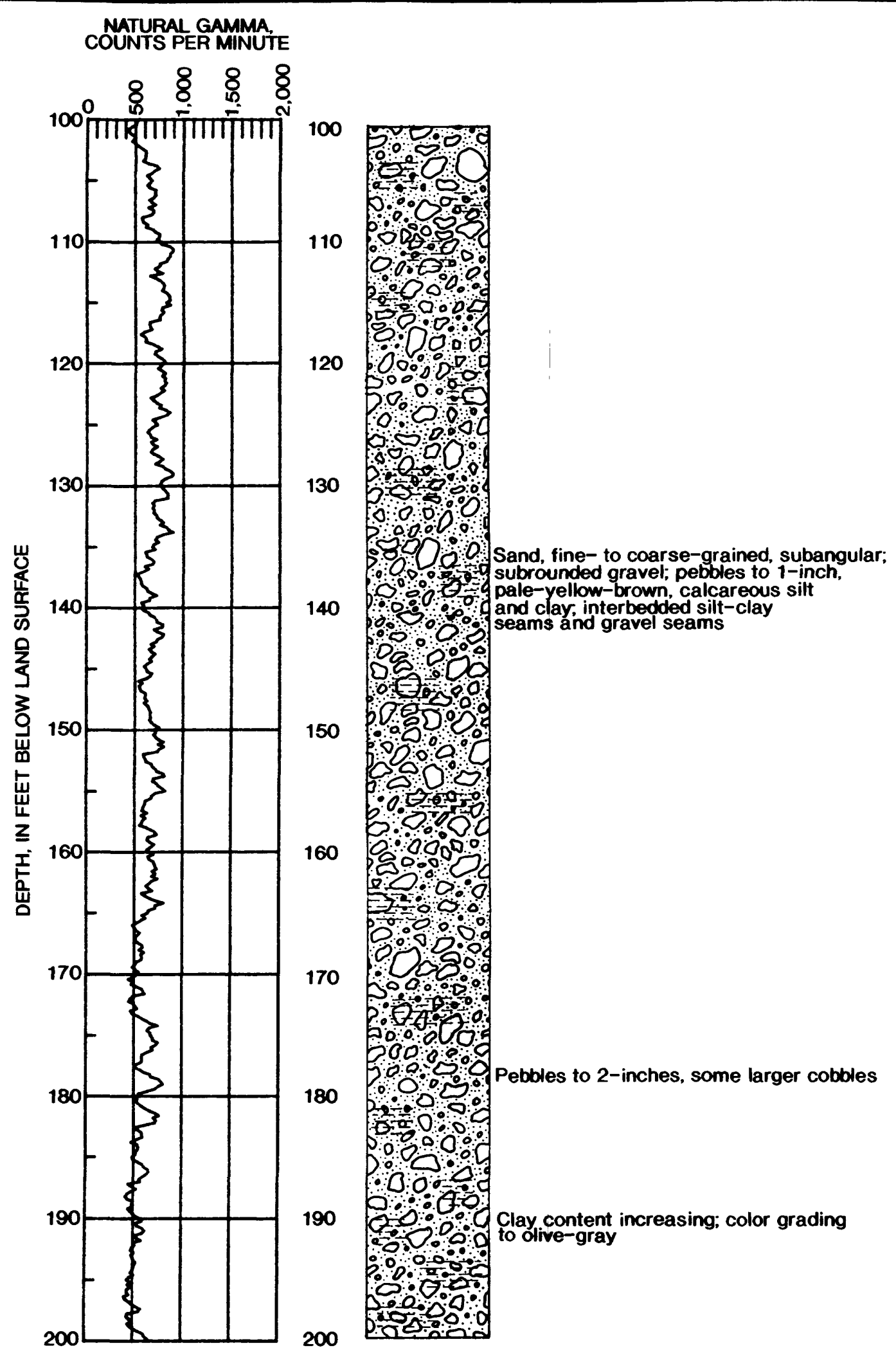

Figure 18.--Natural-gamma and lithologic logs for well GR-304 (cluster 4) --Continued. 


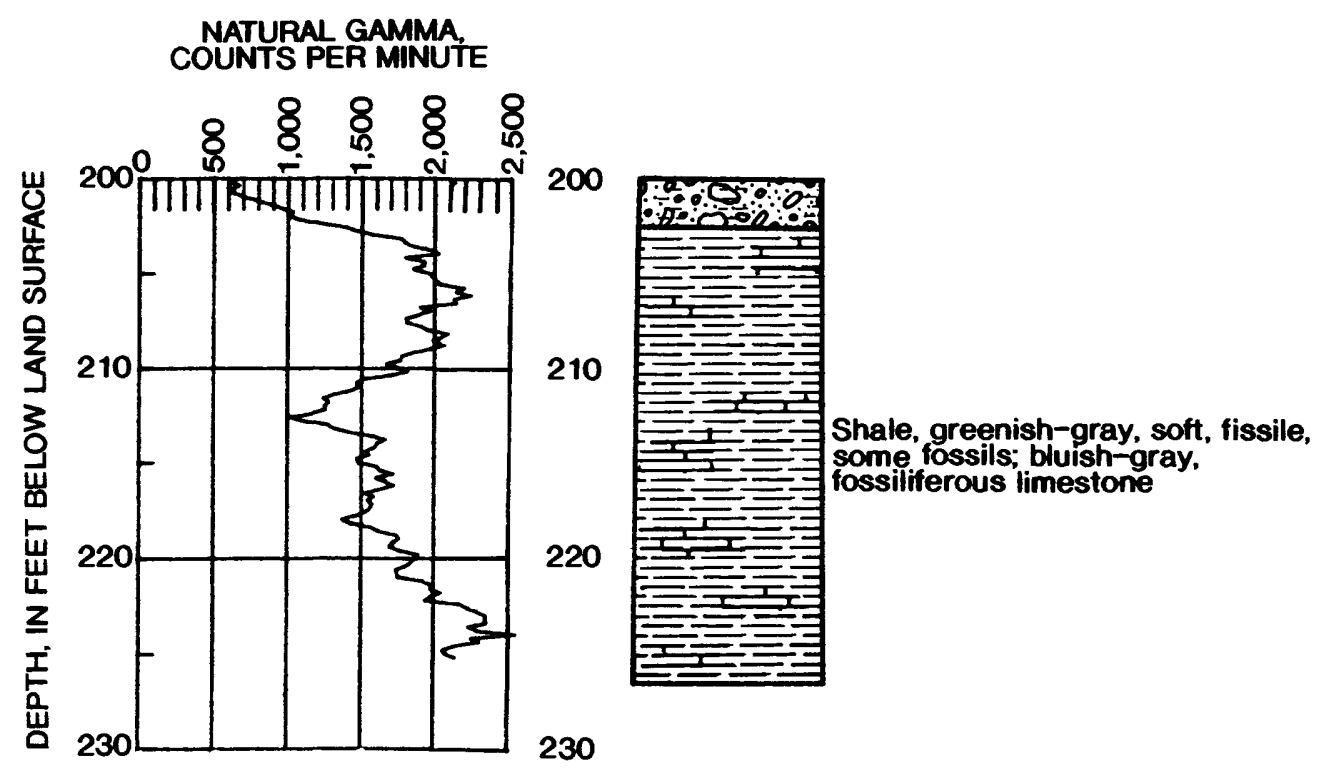

Figure 18.--Natural-gamma and lithologic logs for well GR-304 (cluster 4)--Continued. 


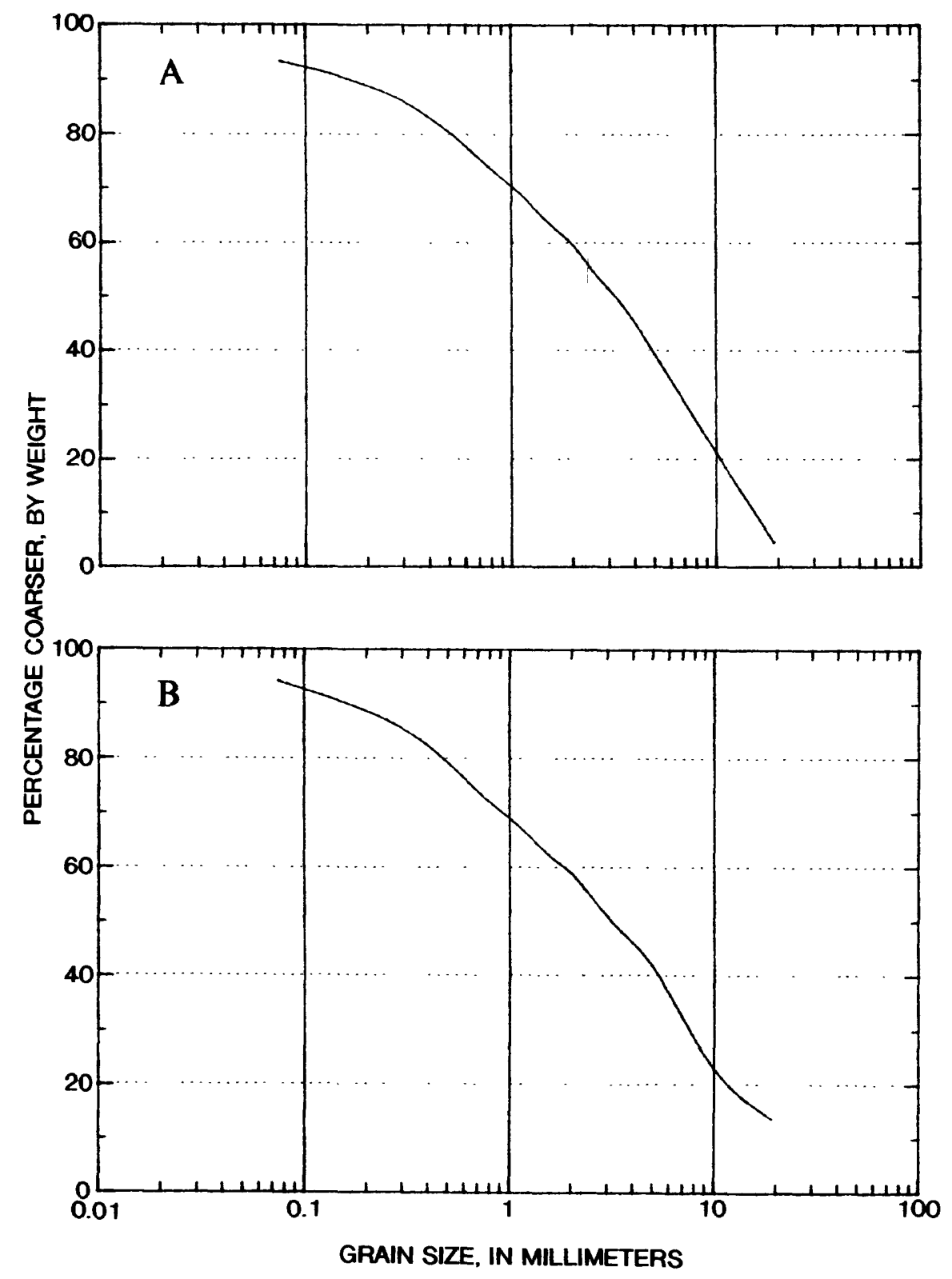

Figure 19.--Grain-size distributions of sediment samples from well GR-304 (cluster 4) (A) 339.5 to 41.5 feet and (B) 139.7 to 141.7 feet. 


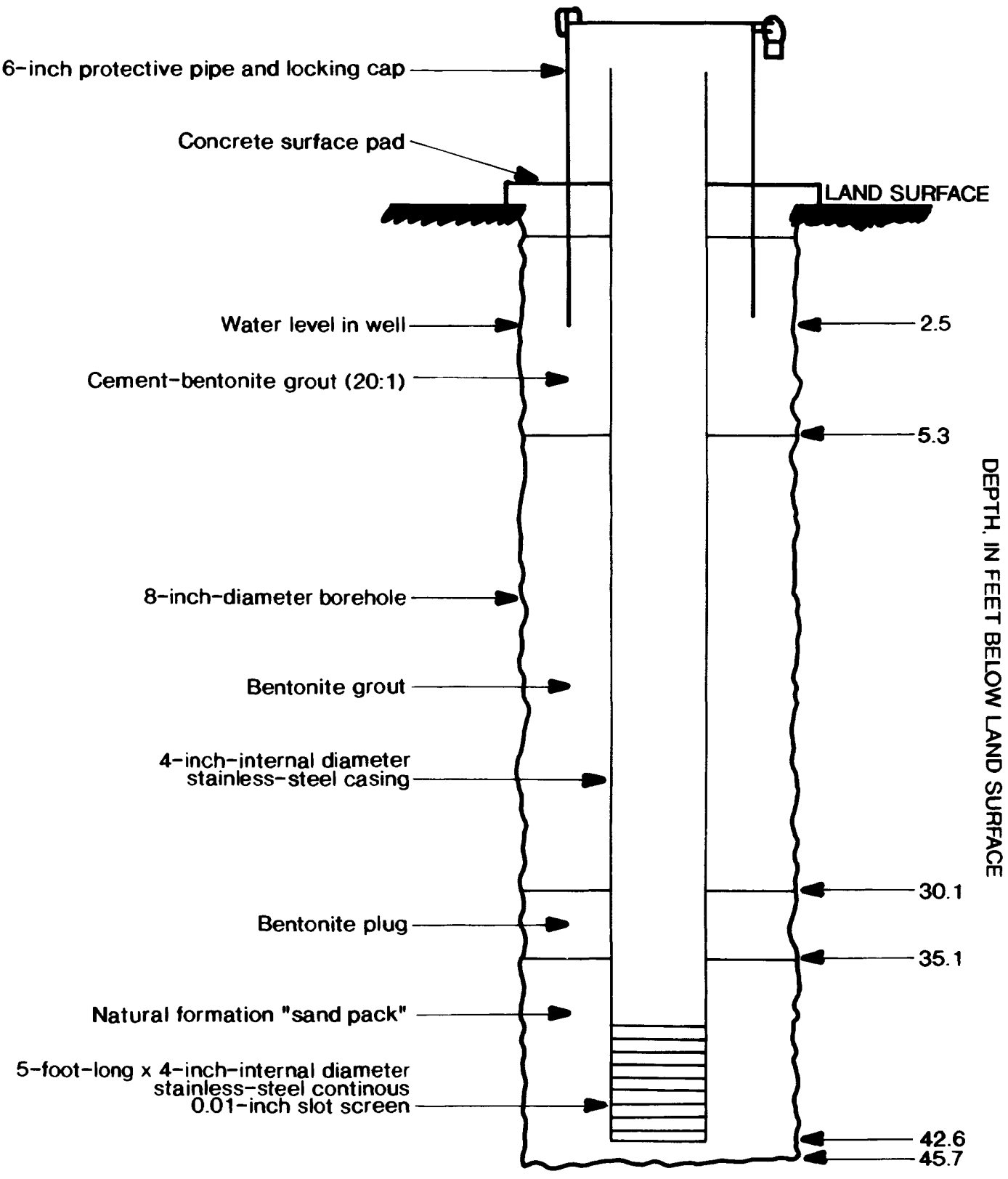

Not to scale

Figure 20.--Construction diagram for well GR-321 


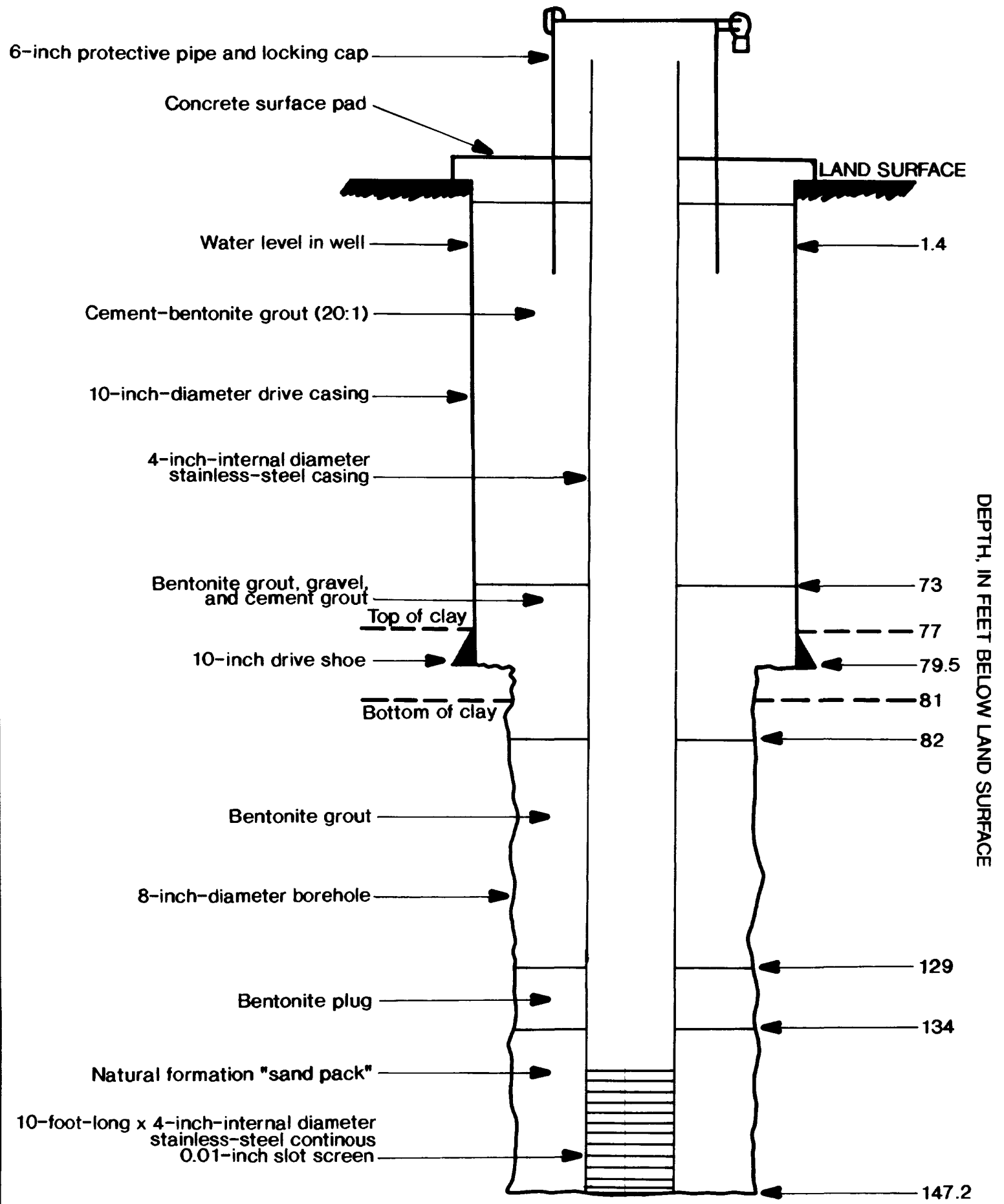

Not to scale

Figure 21.--Construction diagram for well GR-322. 


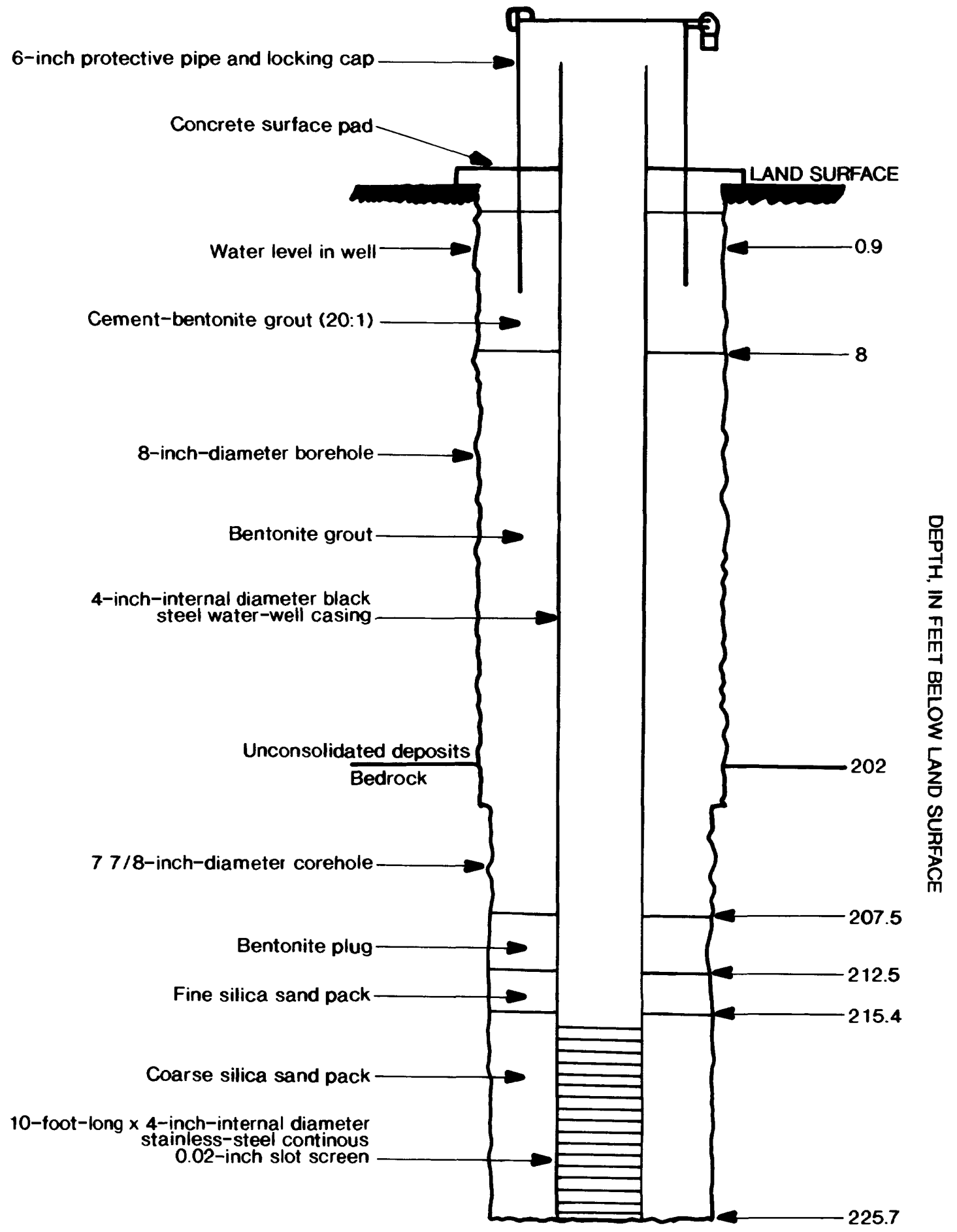

Figure 22.--Construction diagram for well GR-304 


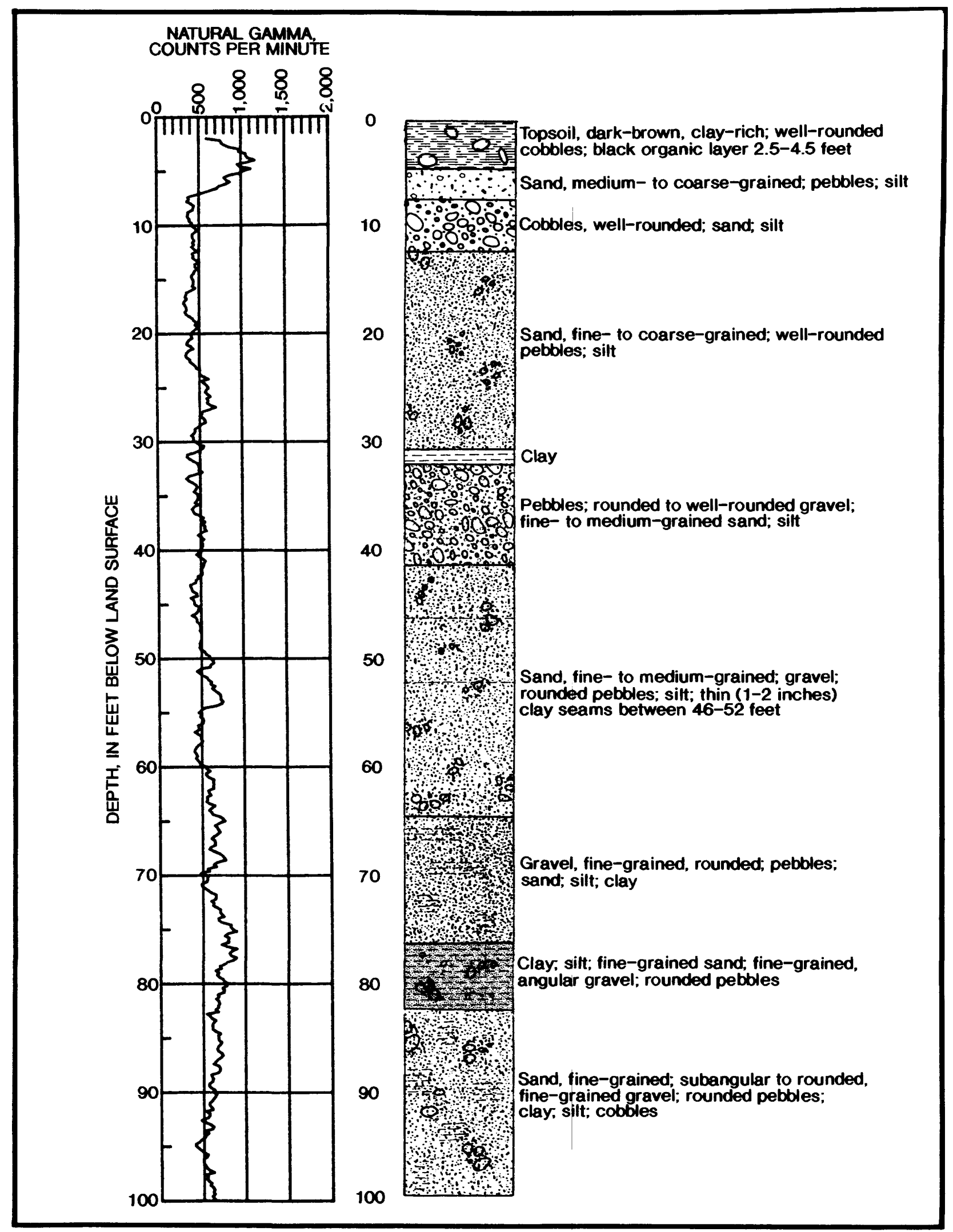

Figure 23.--Natural-gamma and lithologic logs for well GR-305 (cluster 5). 


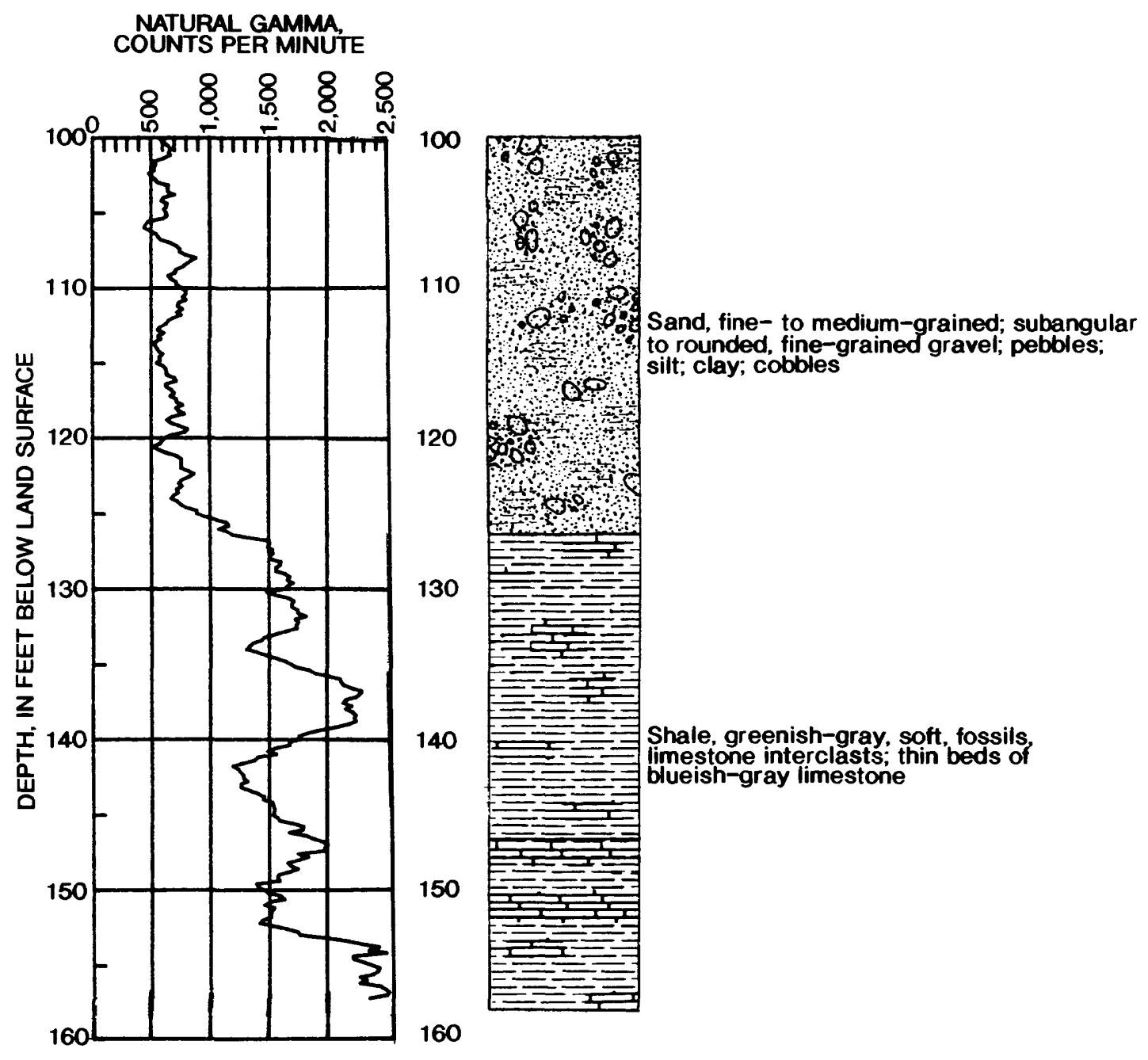

Figure 23.--Natural-gamma and lithologic logs for well GR-305 (cluster 5)--Continued. 


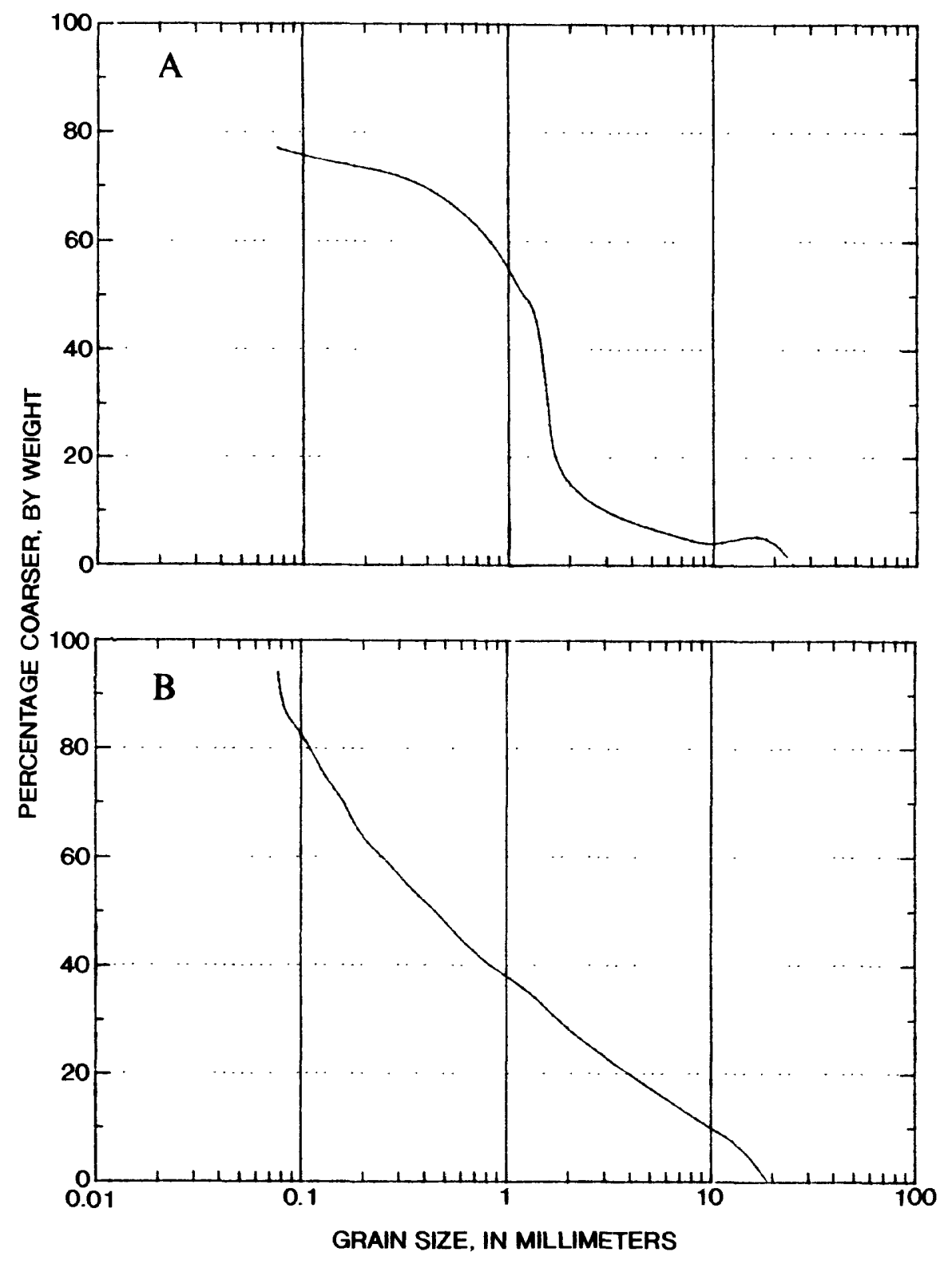

Figure 24.- Grain-size distributions of sediment samples from well GR-305 (cluster 5) (A) 46.8 to 49.1 feet and (B) 118.7 to 120.9 feet. 


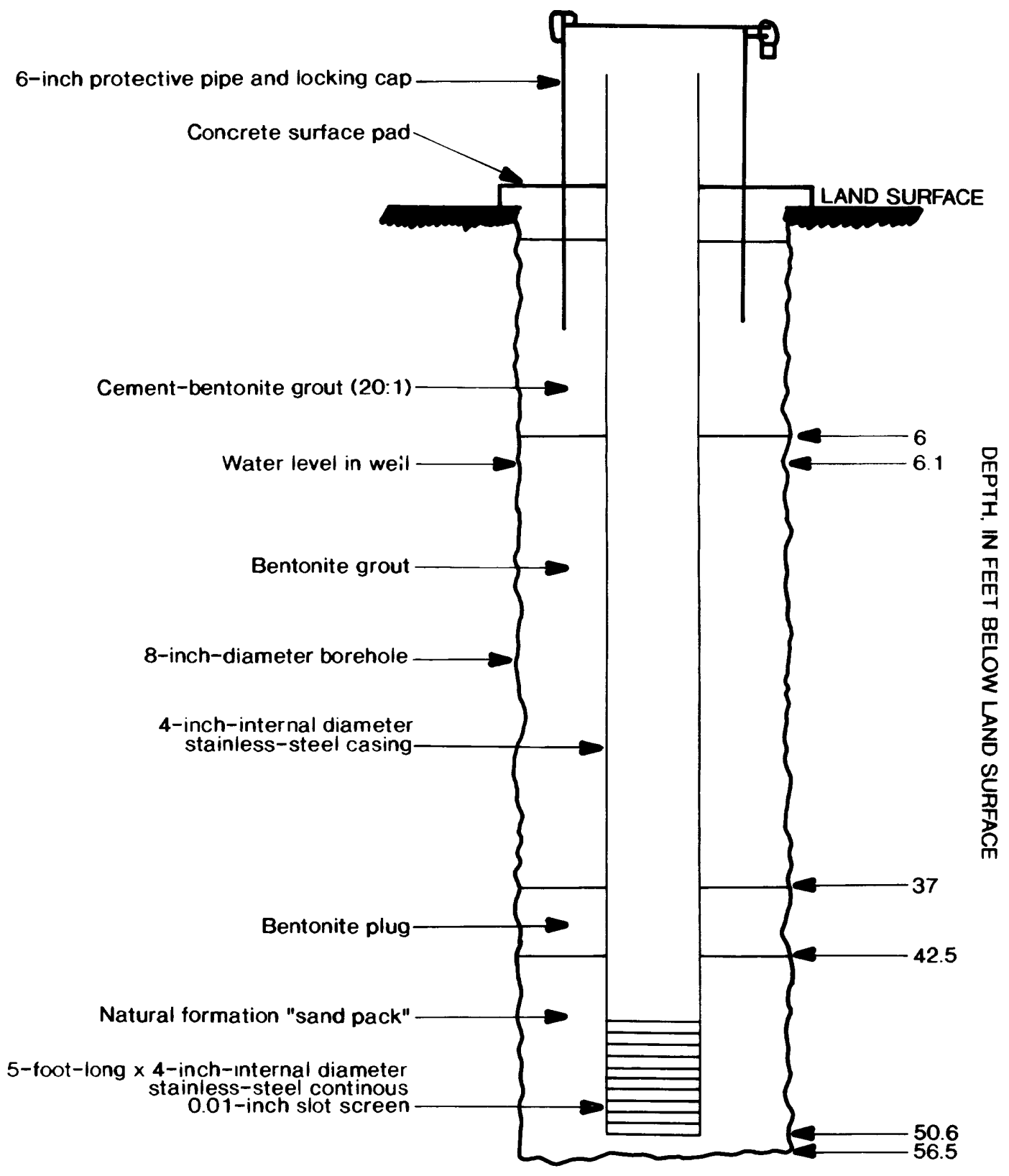

Figure 25.--Construction diagram for well GR-323 


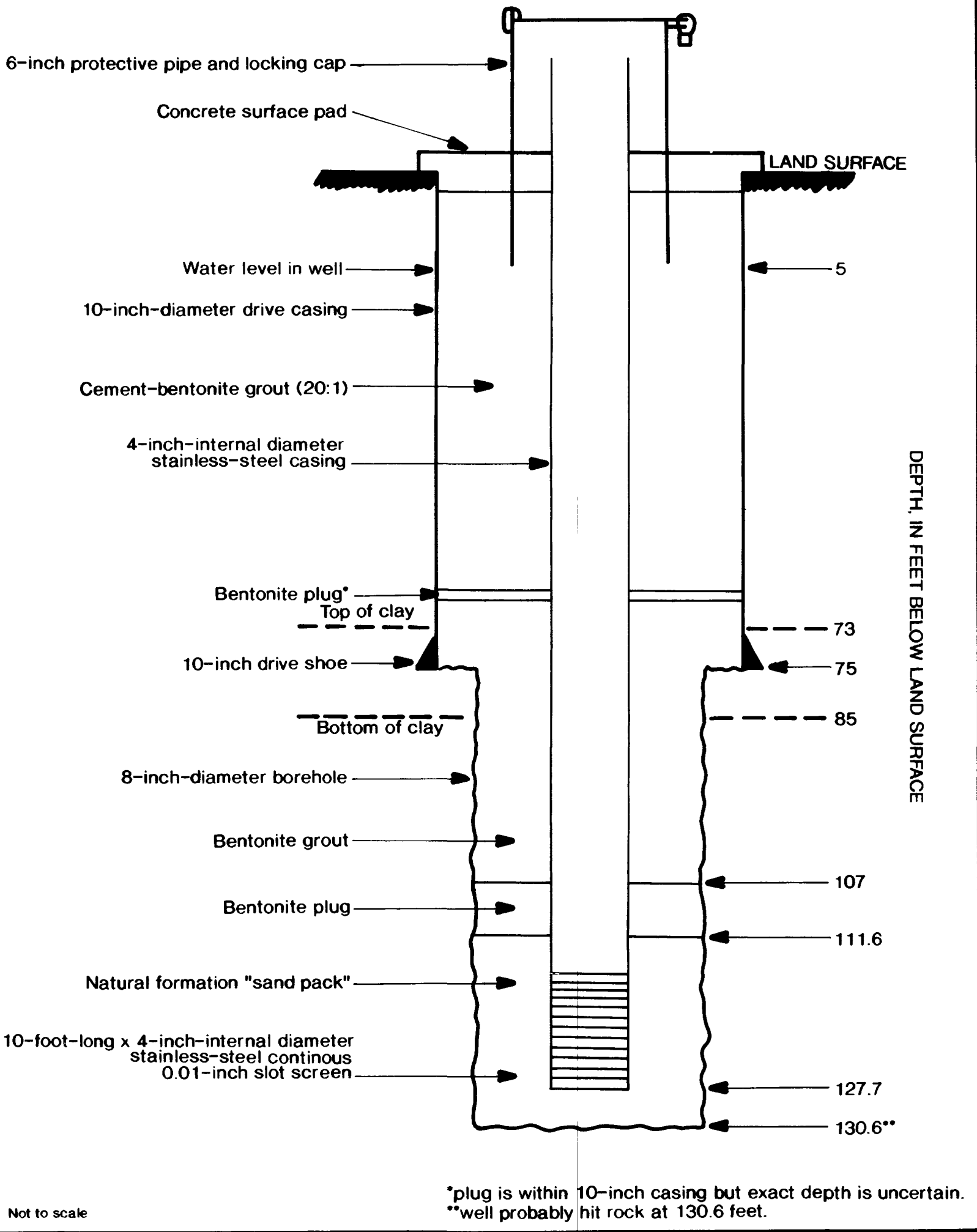

Figure 26.--Construction diagram for well GR-324. 


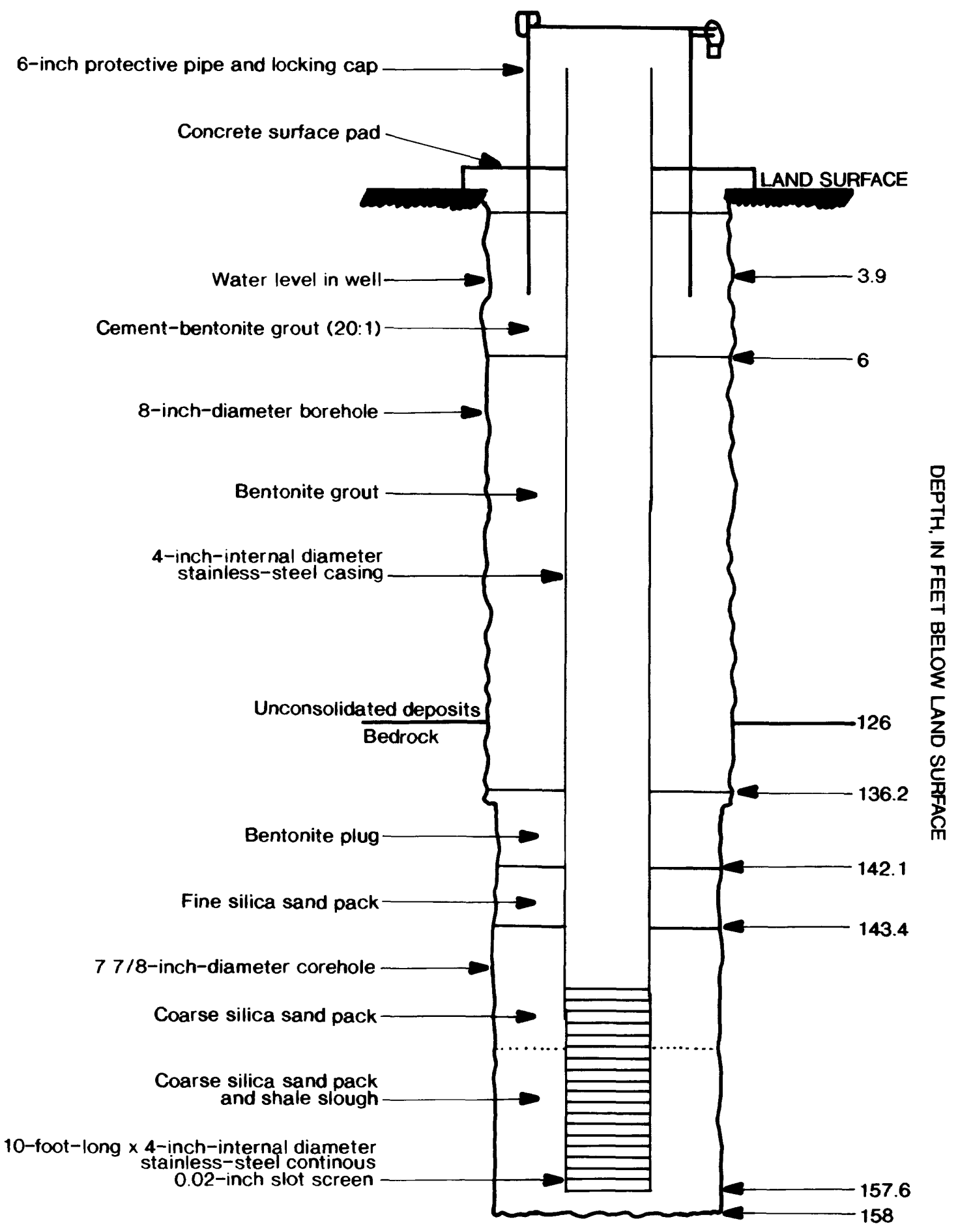

Not to scale

Figure 27.--Construction diagram for well GR-305. 


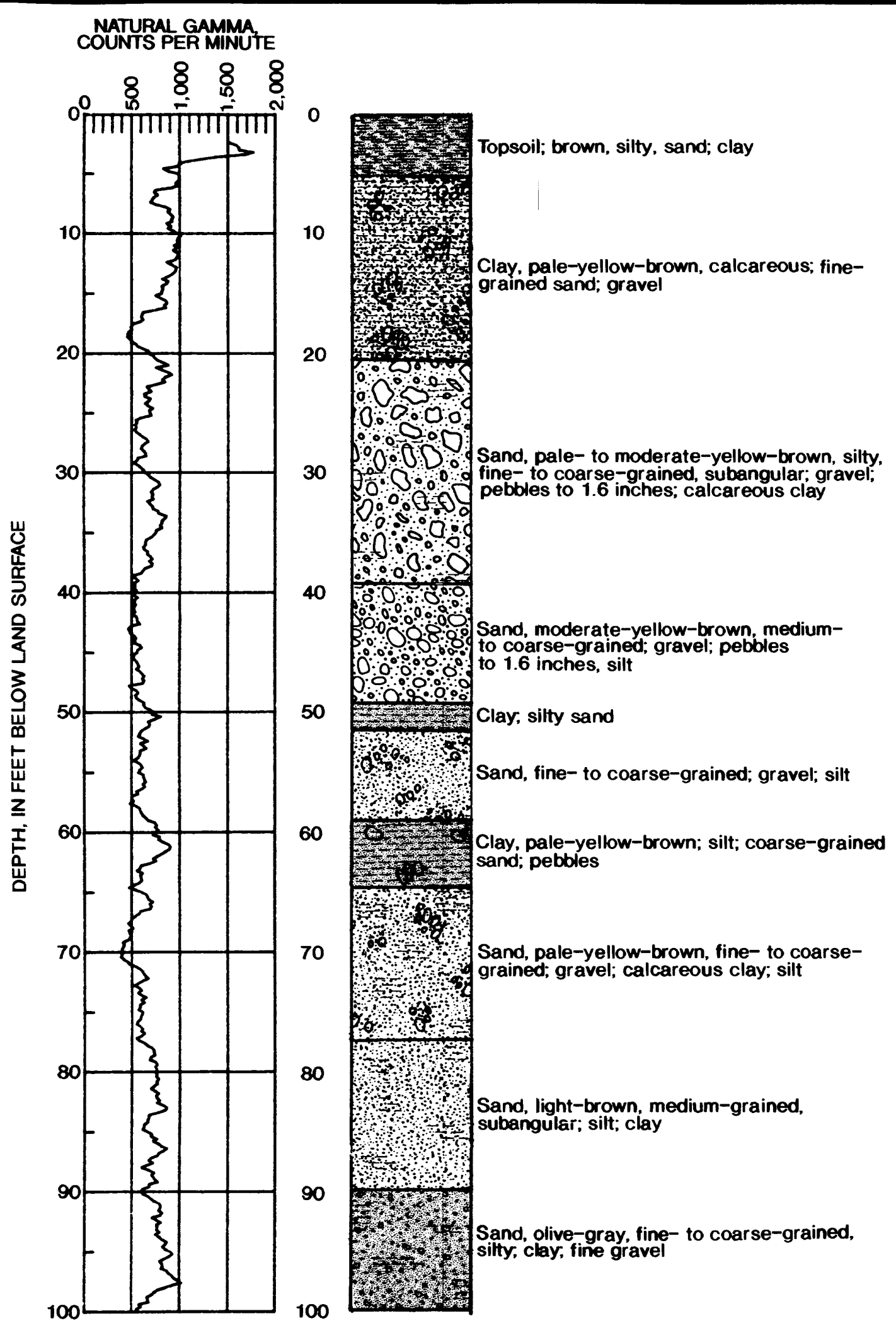

Figure 28.--Natural-gamma and lithologic logs for well GR-306 (cluster 6). 


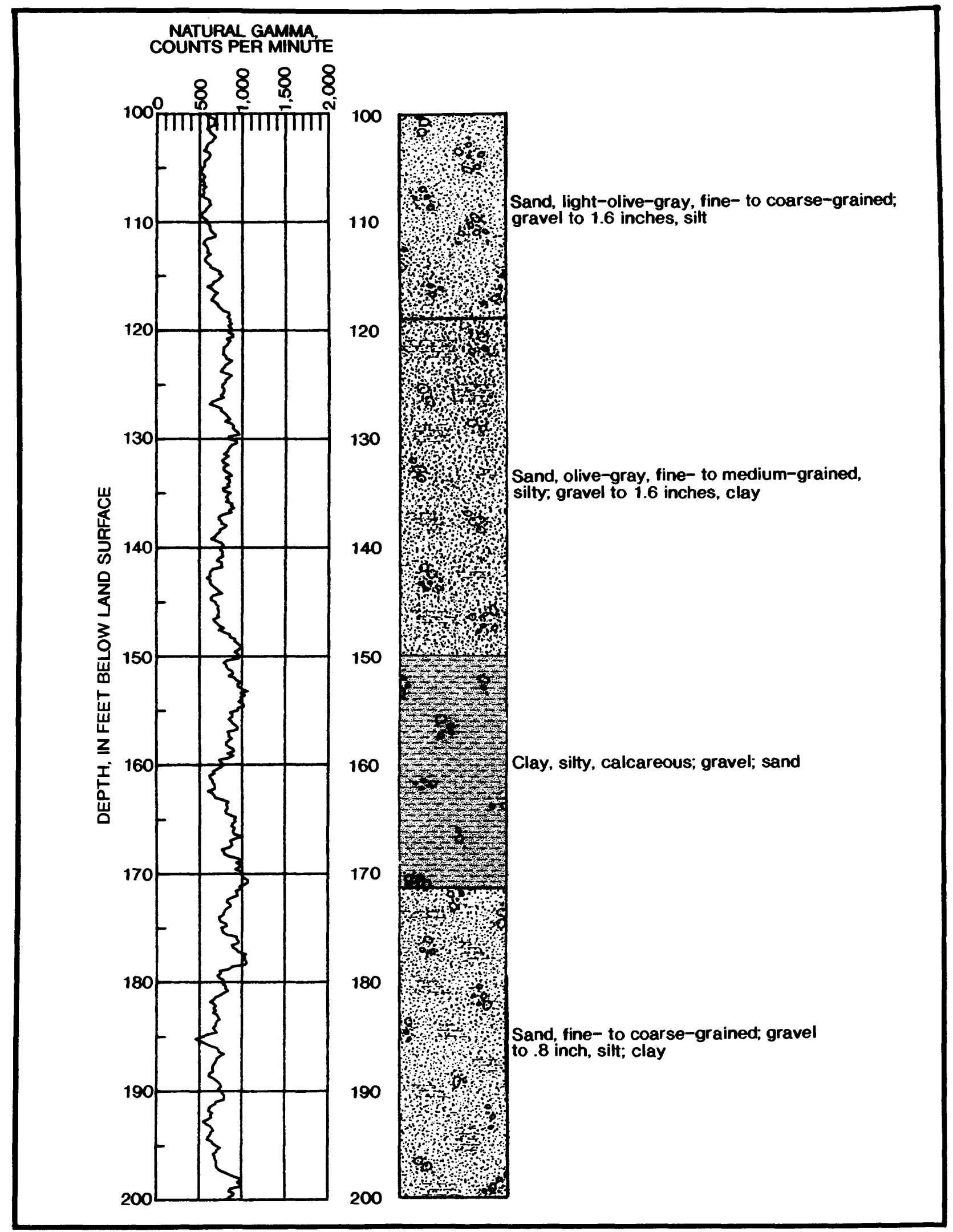

Figure 28.--Natural-gamma and lithologic logs for well GR-306 (cluster 6)--Continued. 


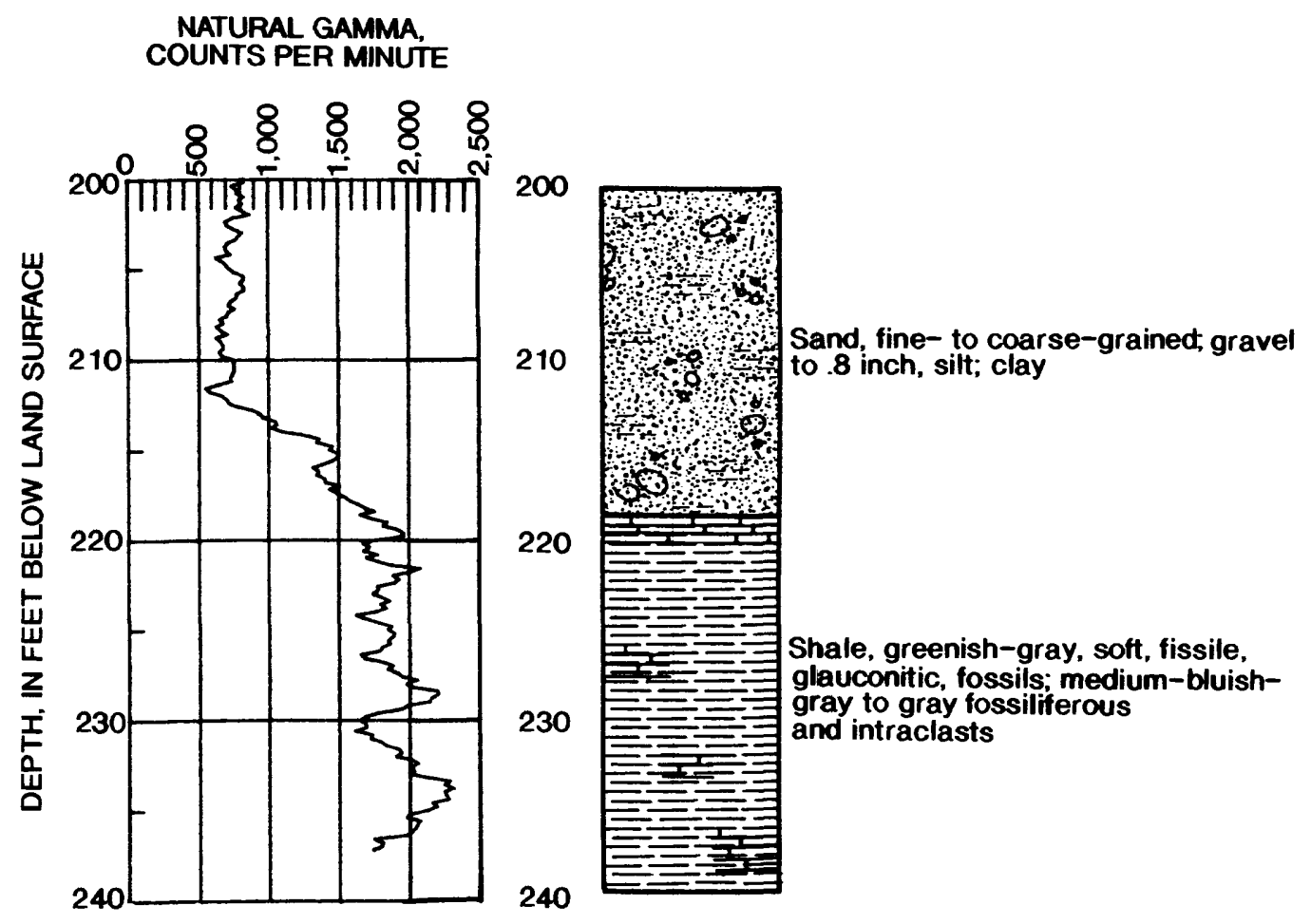

Figure 28.--Natural-gamma and lithologic logs for well GR-306 (cluster 6)--Continued. 


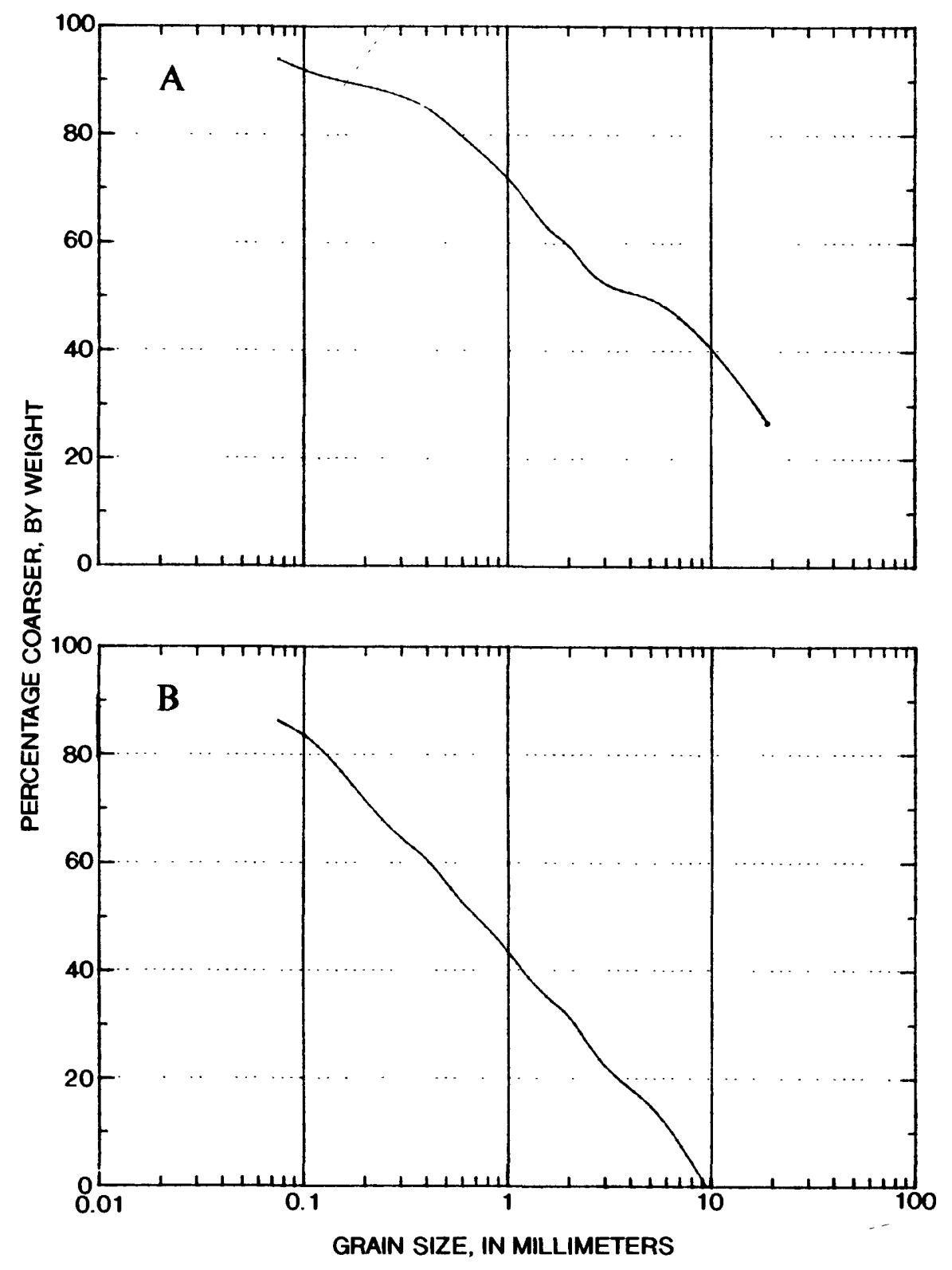

Figure 29.--Grain-size distributions of sediment samples from well GR-306 (cluster 6) (A) 44.2 to 46.2 feet and (B) 63.9 to 65.9 feet. 


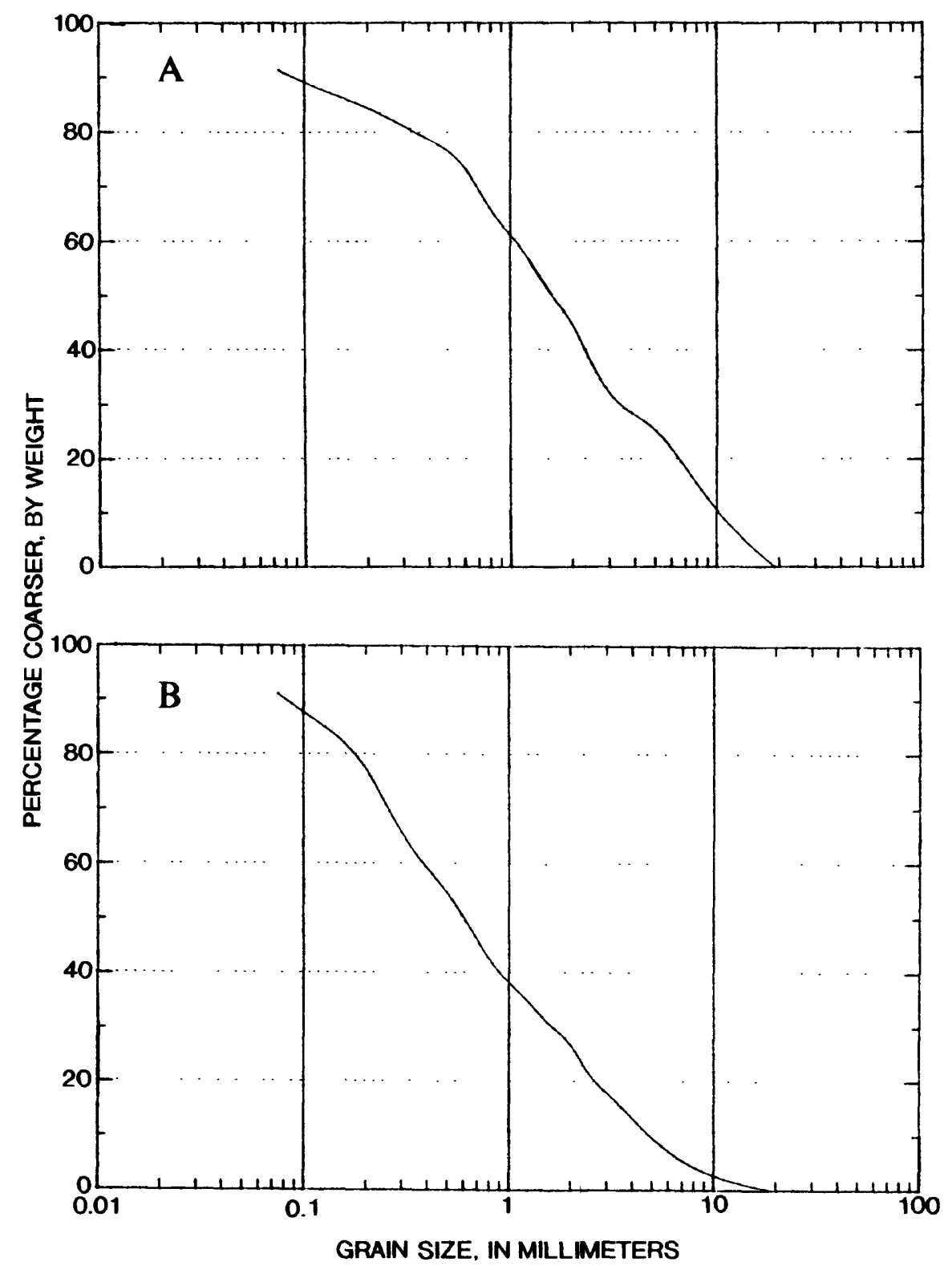

Figure 30.--Grain-size distributions of sediment samples from well GR-306 (cluster 6) (A) 105.3 to 107.3 feet and (B) 111.6 to 113.6 feet. 


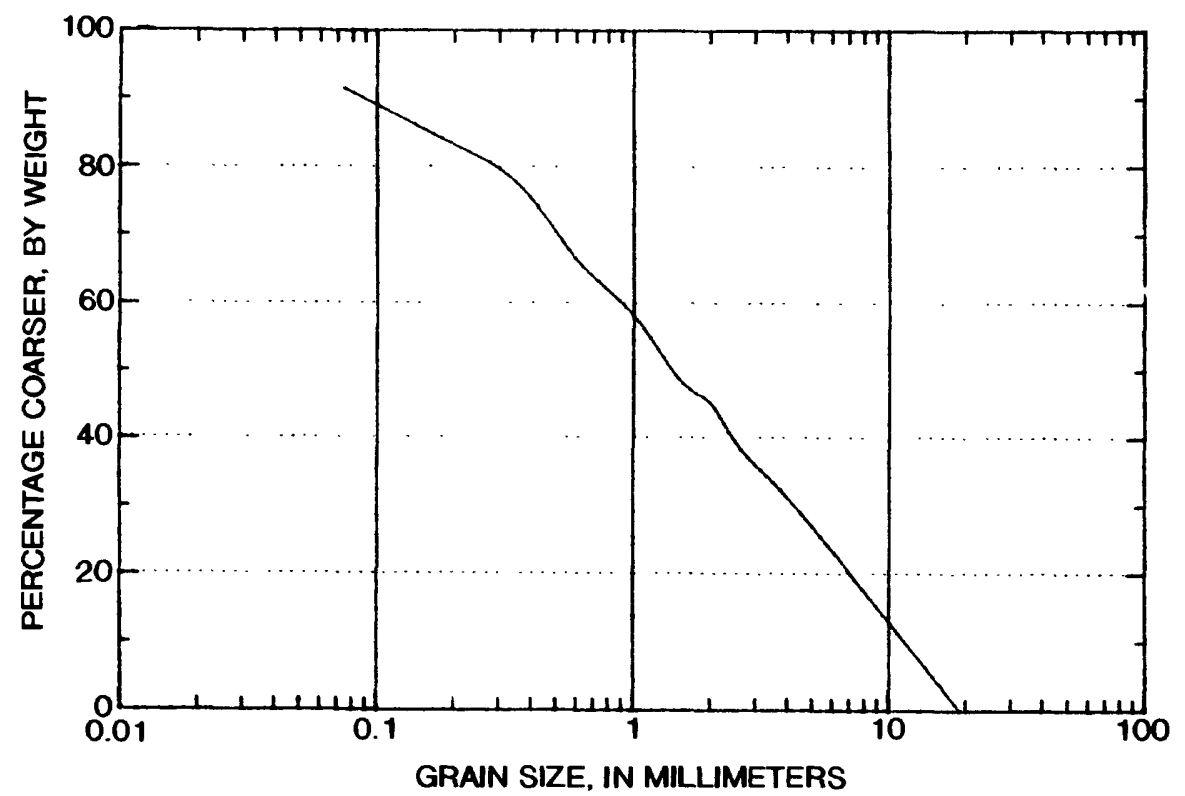

Figure 31.--Grain-size distributions of sediment samples from well GR-306 (cluster 6) 190.7 to 192.7 feet. 


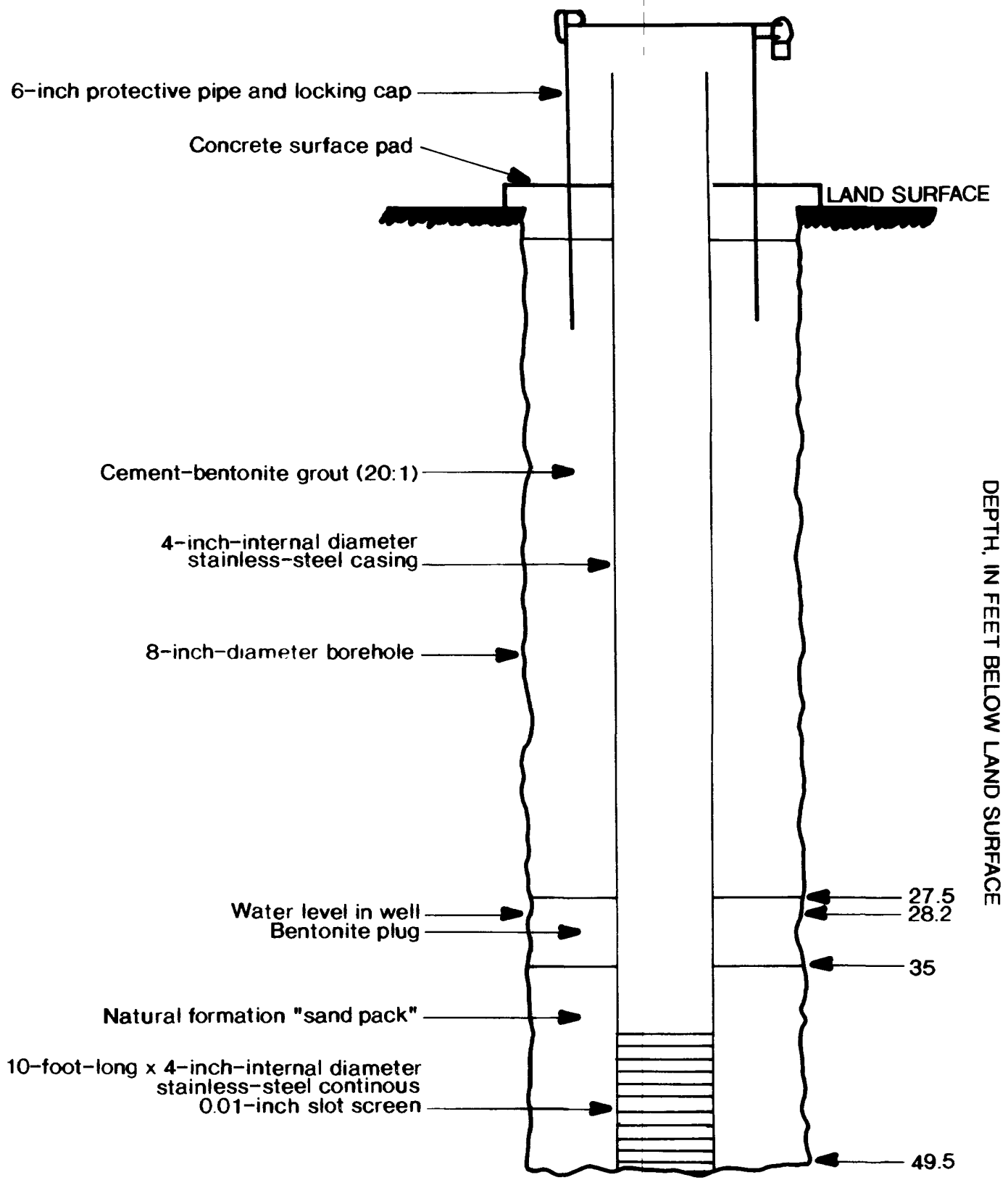

Figure 32.--Construction diagram for well GR-330. 


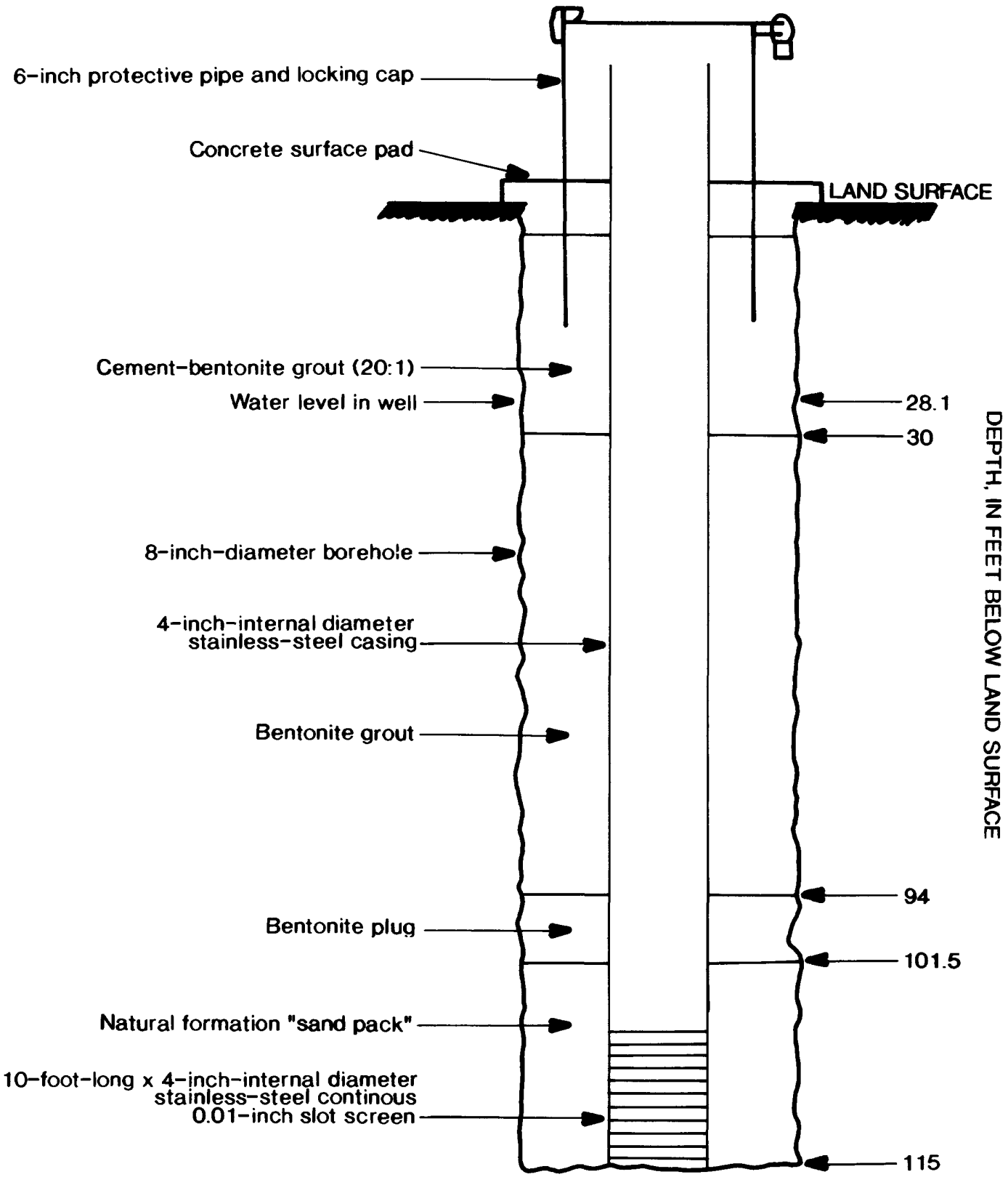

Figure 33.--Construction diagram for well GR-331. 


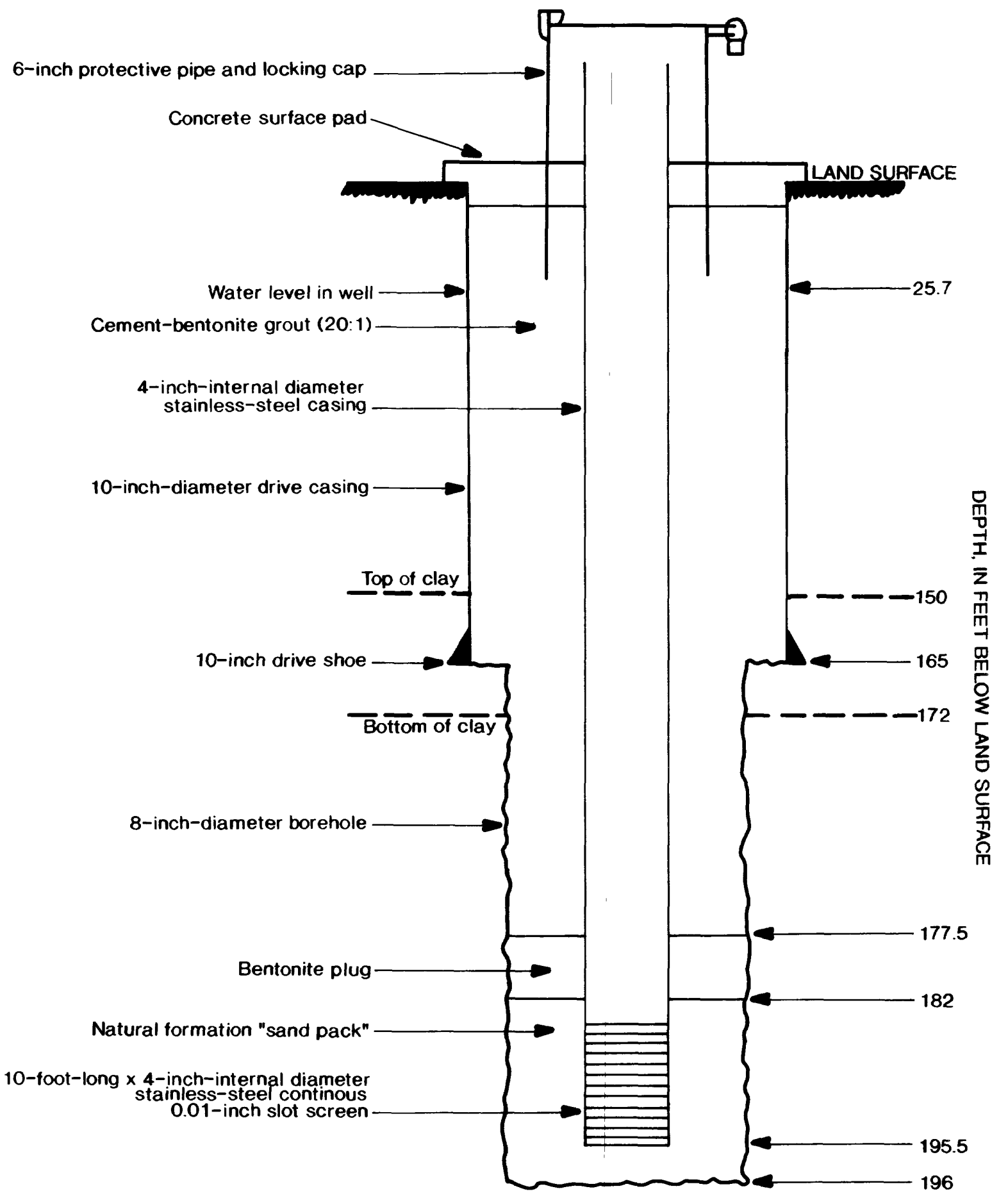

Not to scale

Figure 34.--Construction diagram for well GR-332. 


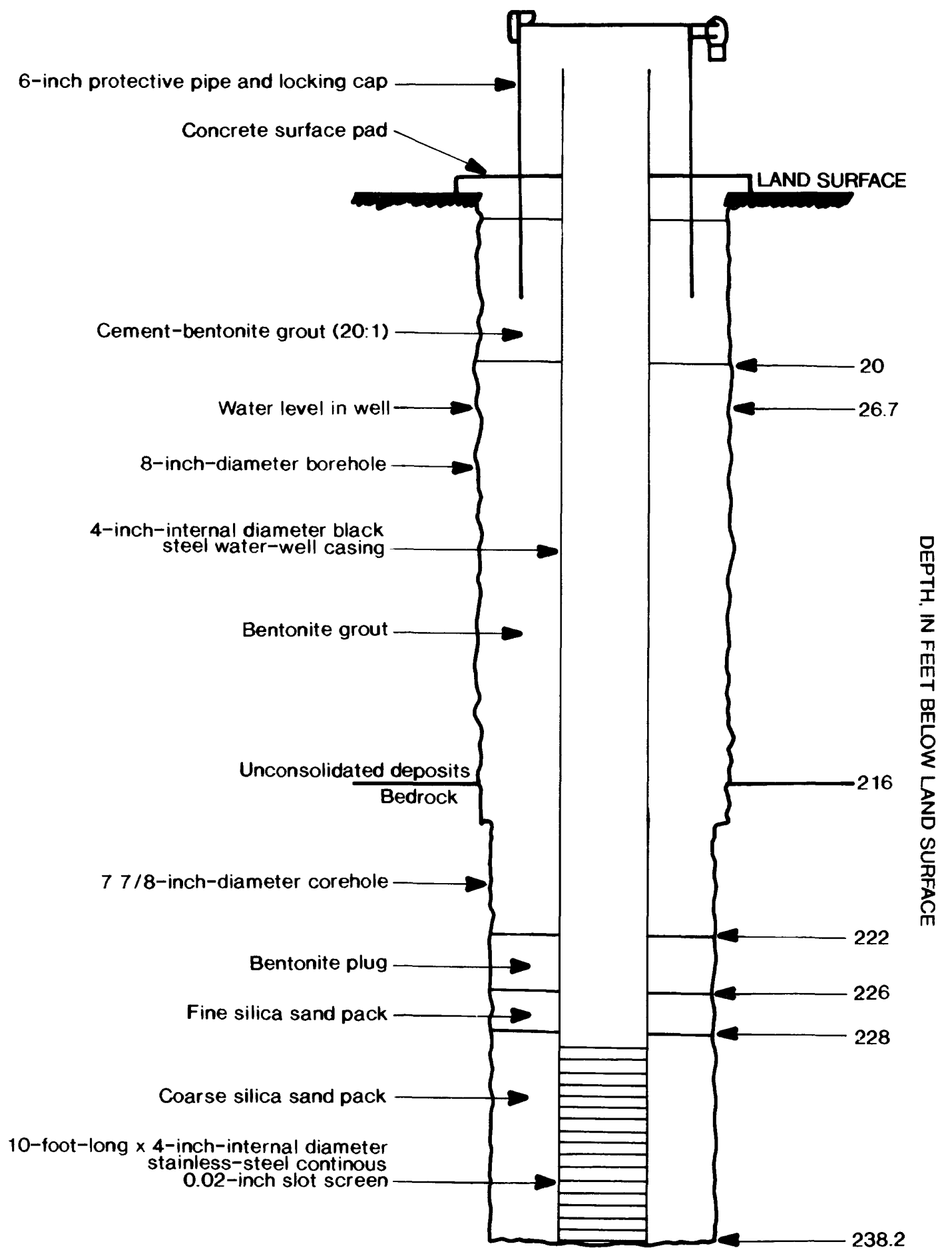

Figure 35---Construction diagram for well GR-306. 


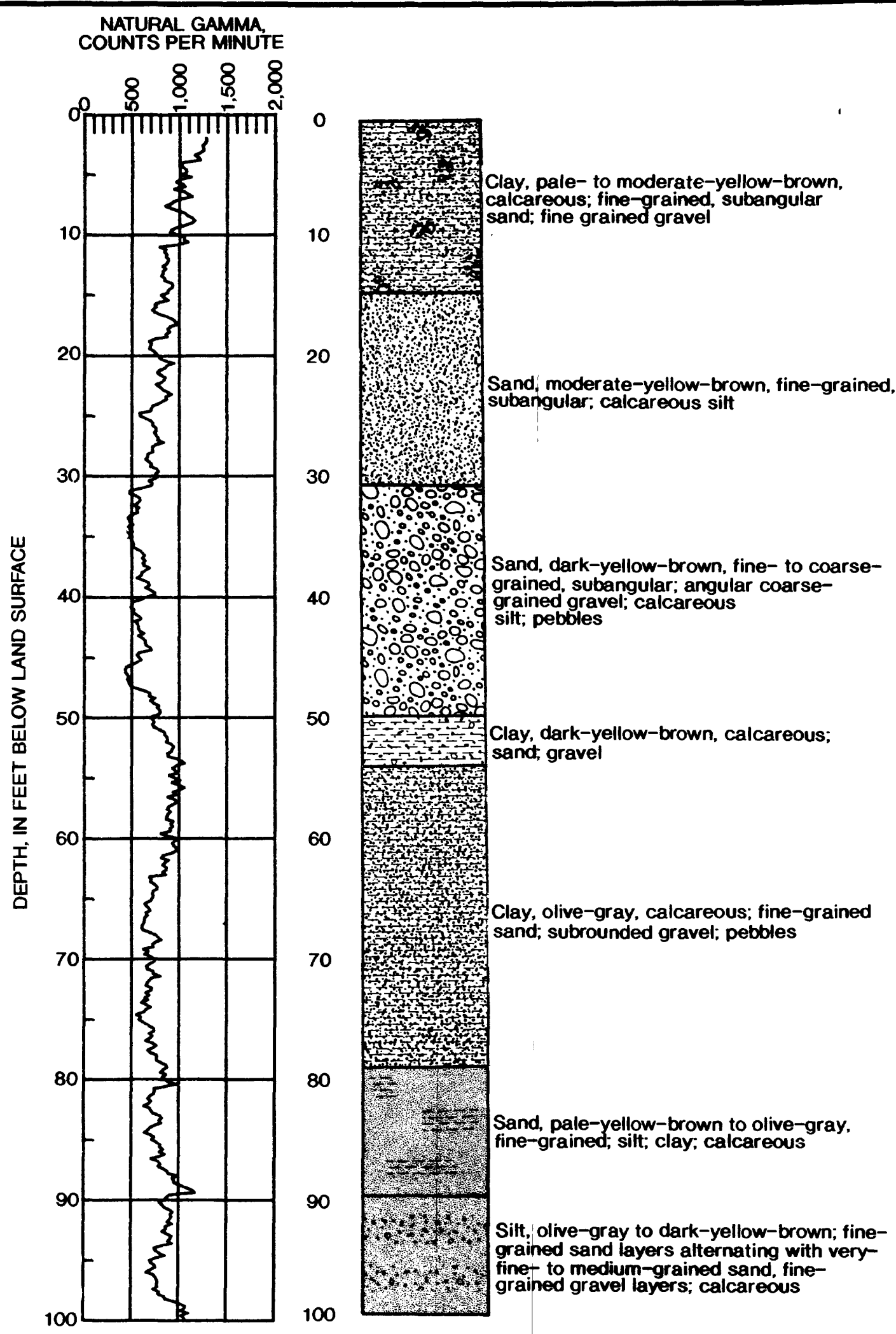

Figure 36.--Natural-gamma and lithologic logs for well GR-307 (cluster 7). 


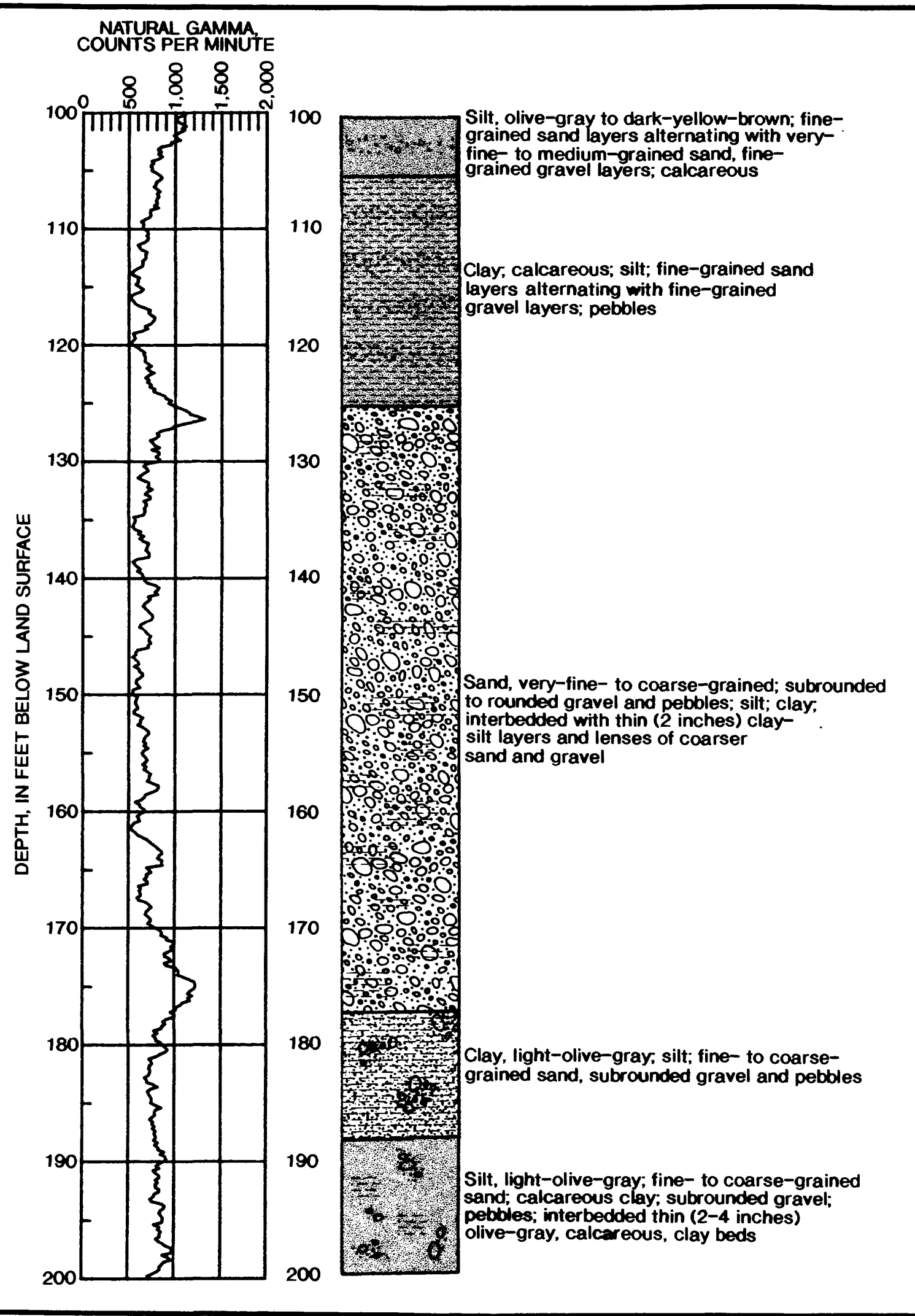

Figure 36.--Natural-gamma and lithologic logs for well GR-307 (cluster 7)--Continued. 


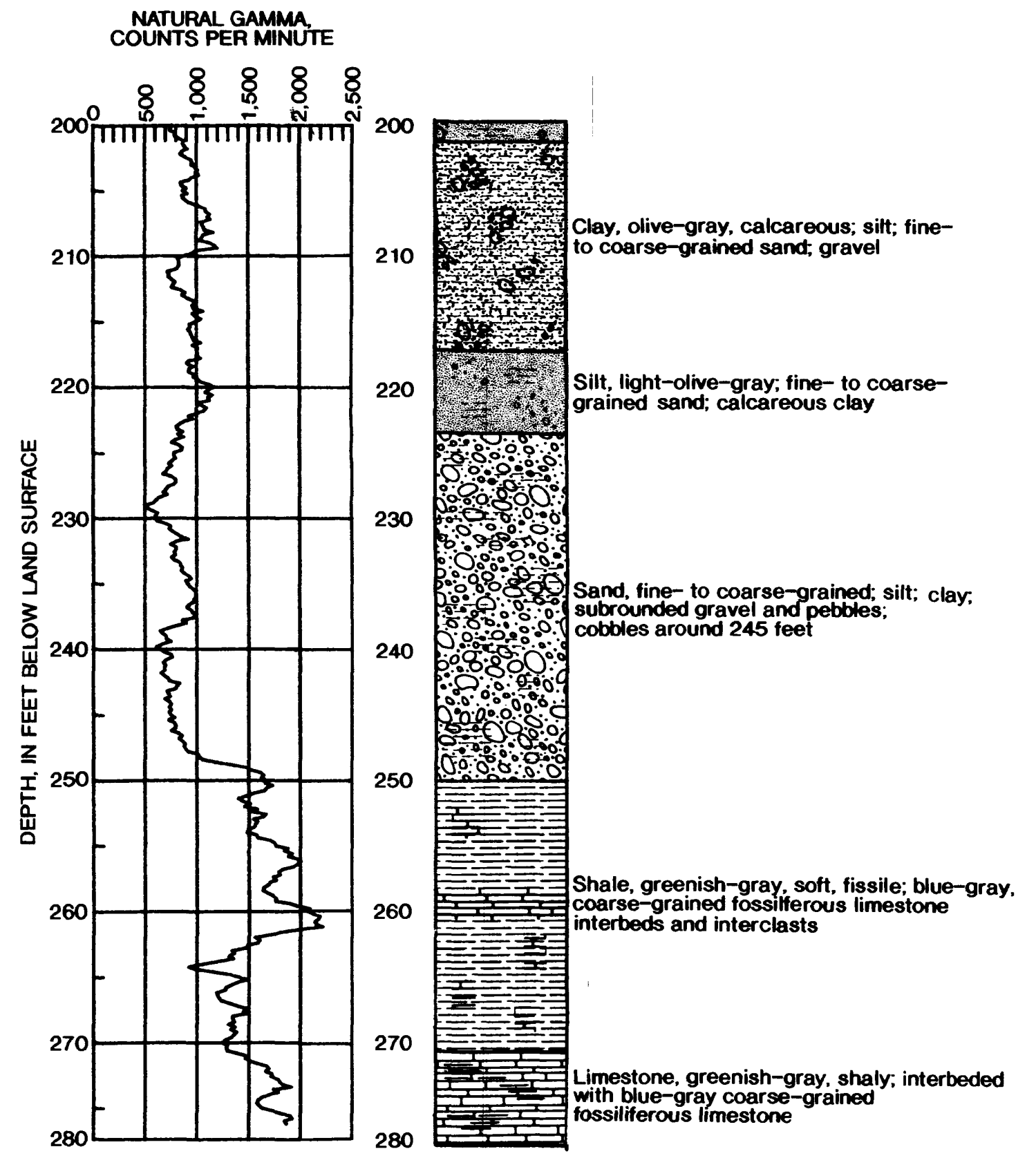

Figure 36.--Natural-gamma and lithologic logs for well GR-307 (cluster 7)--Continued. 


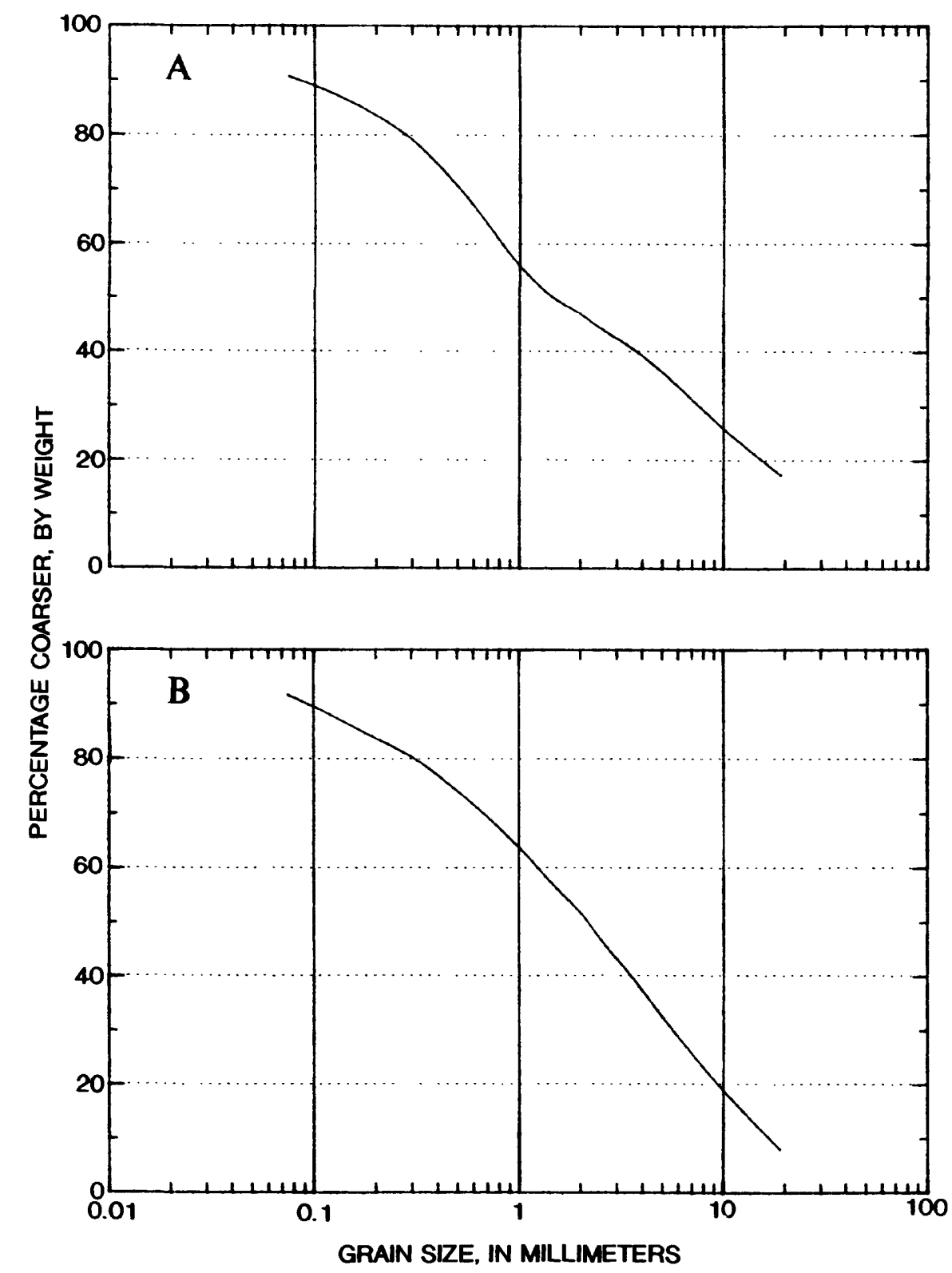

Figure 37.--Grain-size distributions of sediment samples from well GR-307 (cluster 7) (A) 34 TO 36 feet and (B) 153.5 TO 155.5 feet. 


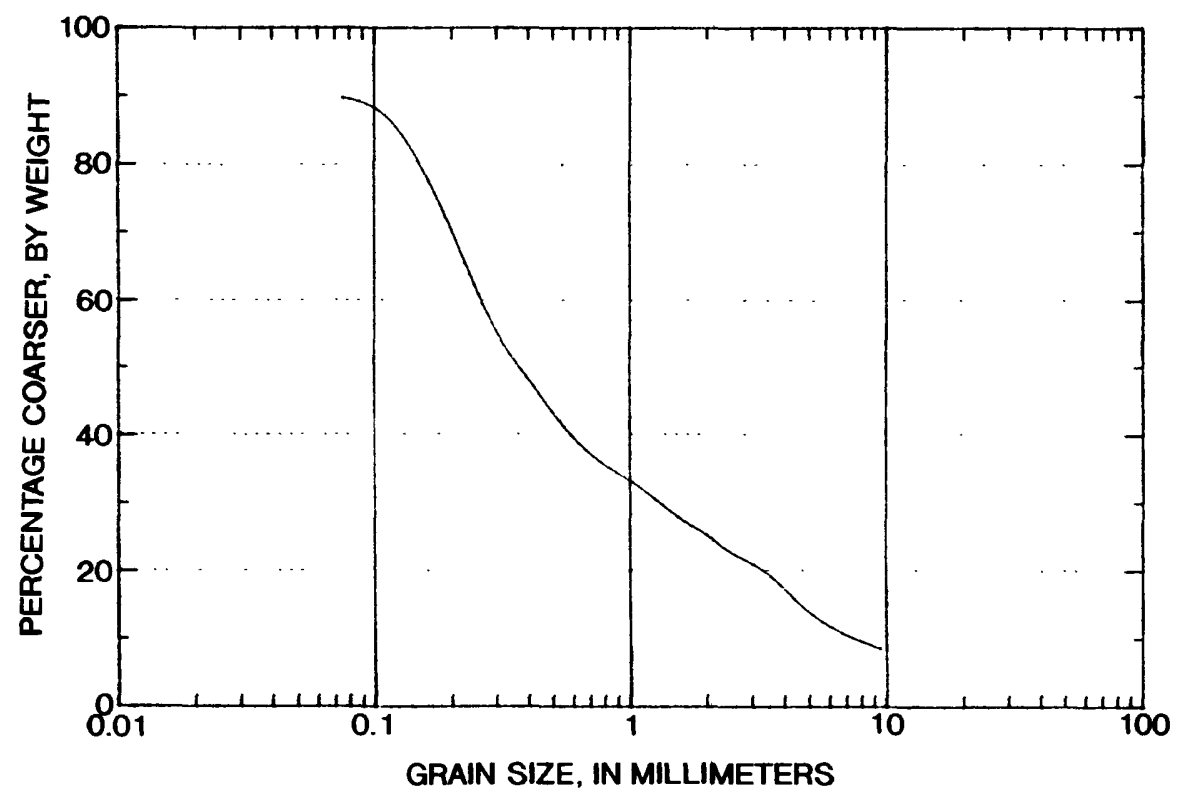

Figure 38.--Grain-size distributions of sediment samples from well GR-307 (cluster 7) 234.9 to 236.9 feet. 


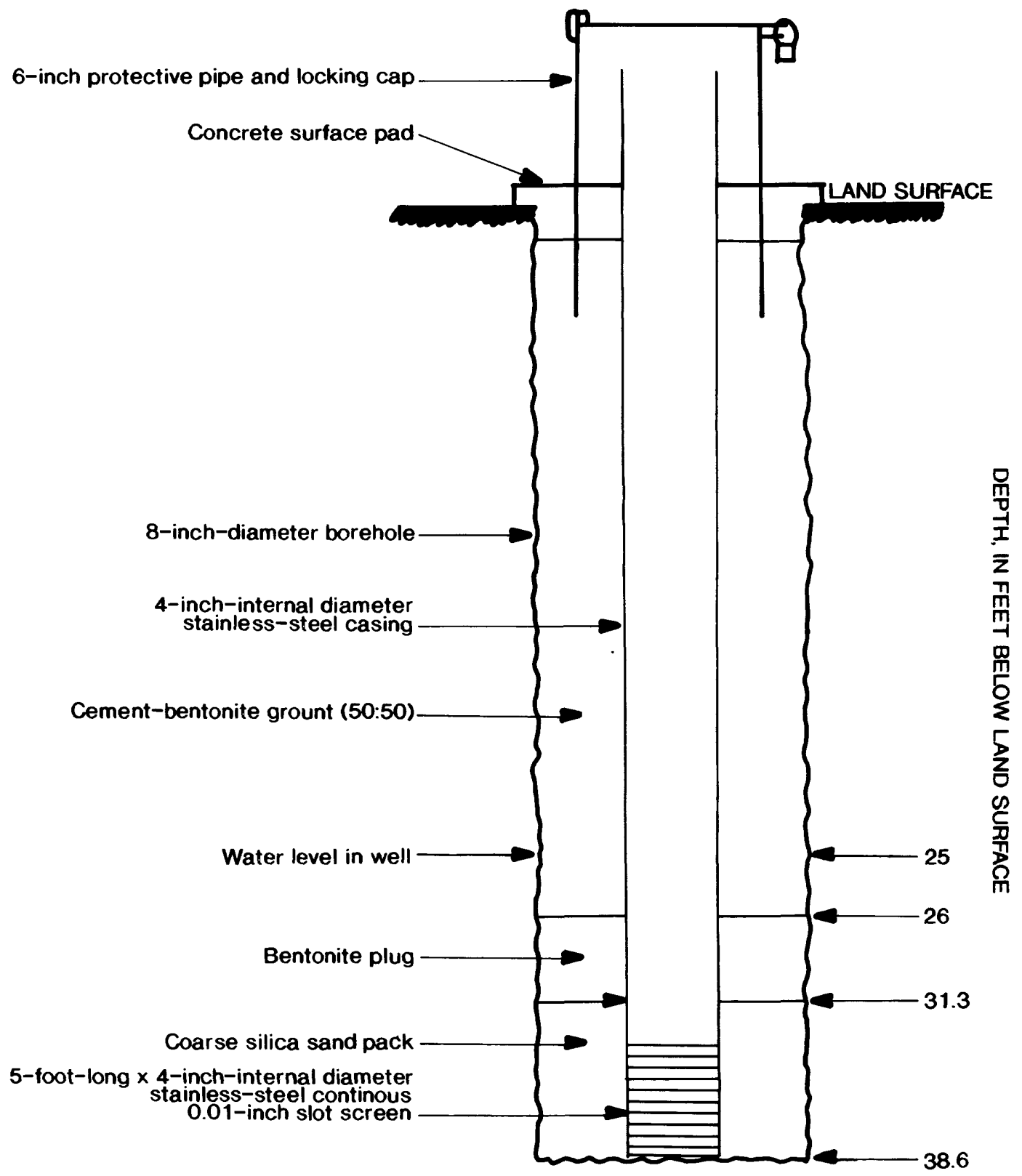

Figure 39.--Construction diagram for well GR-326. 


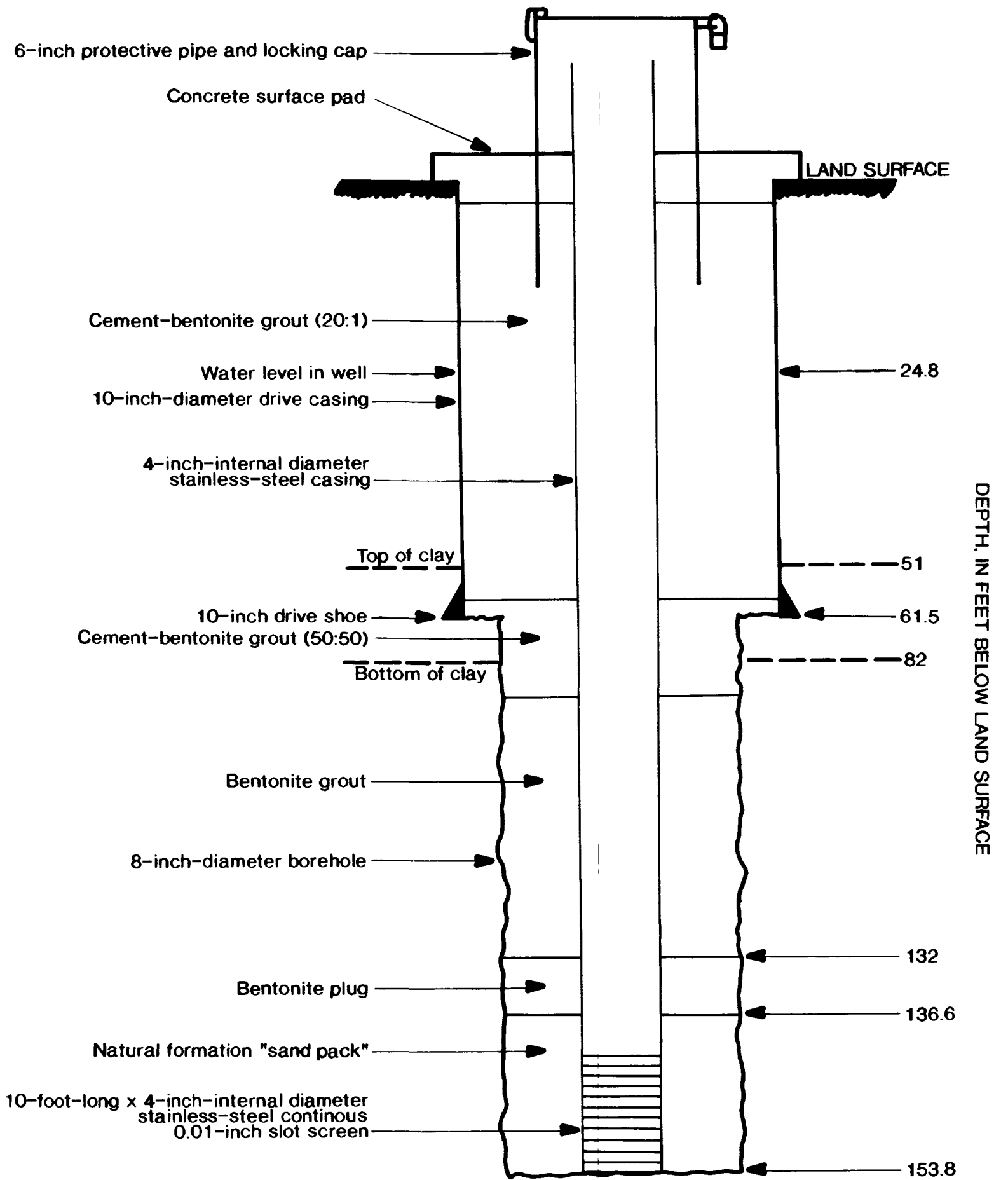

Figure 40.--Construction diagram for well GR-327. 


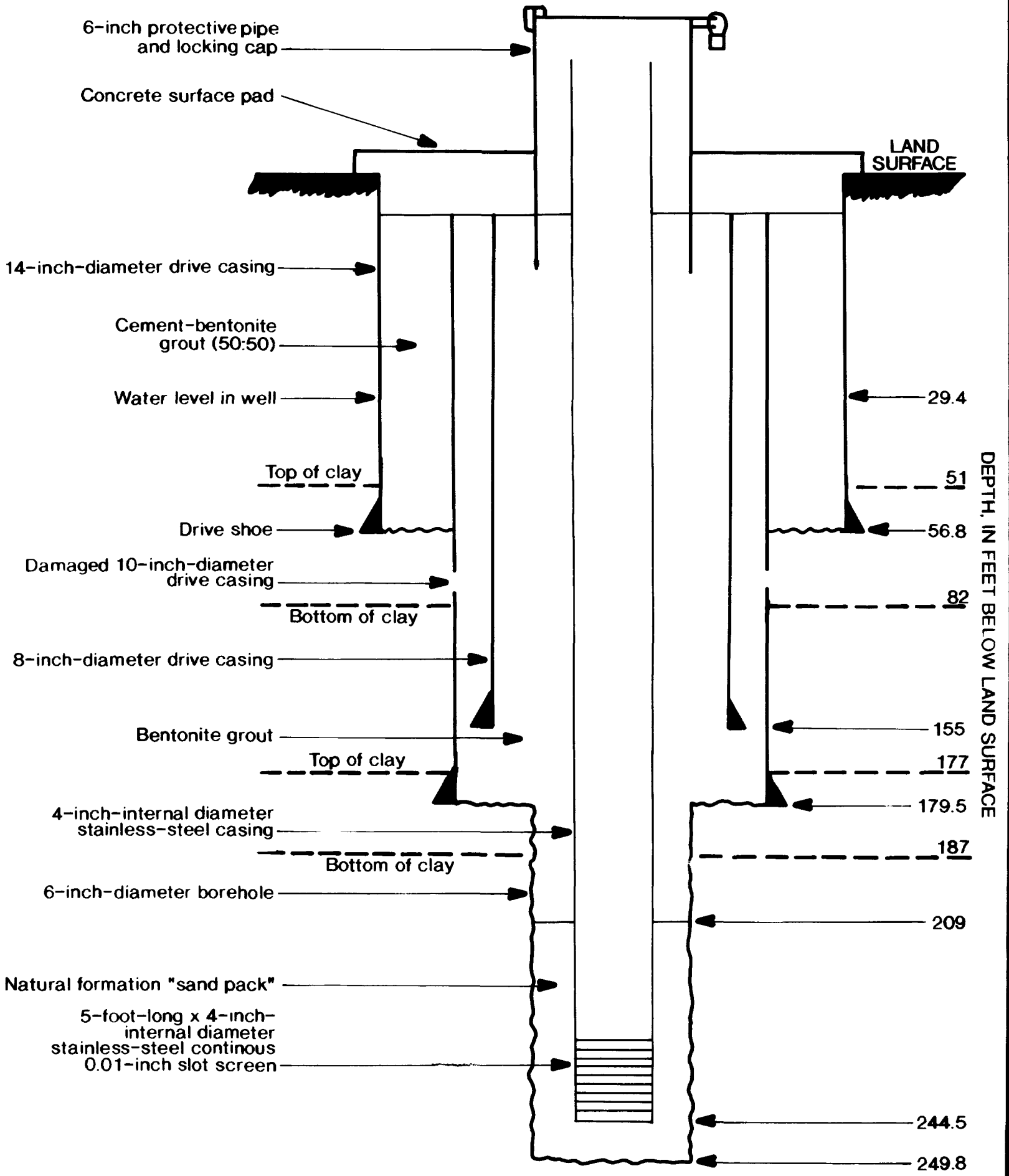

Figure 41.--Construction diagram for well GR-328. 


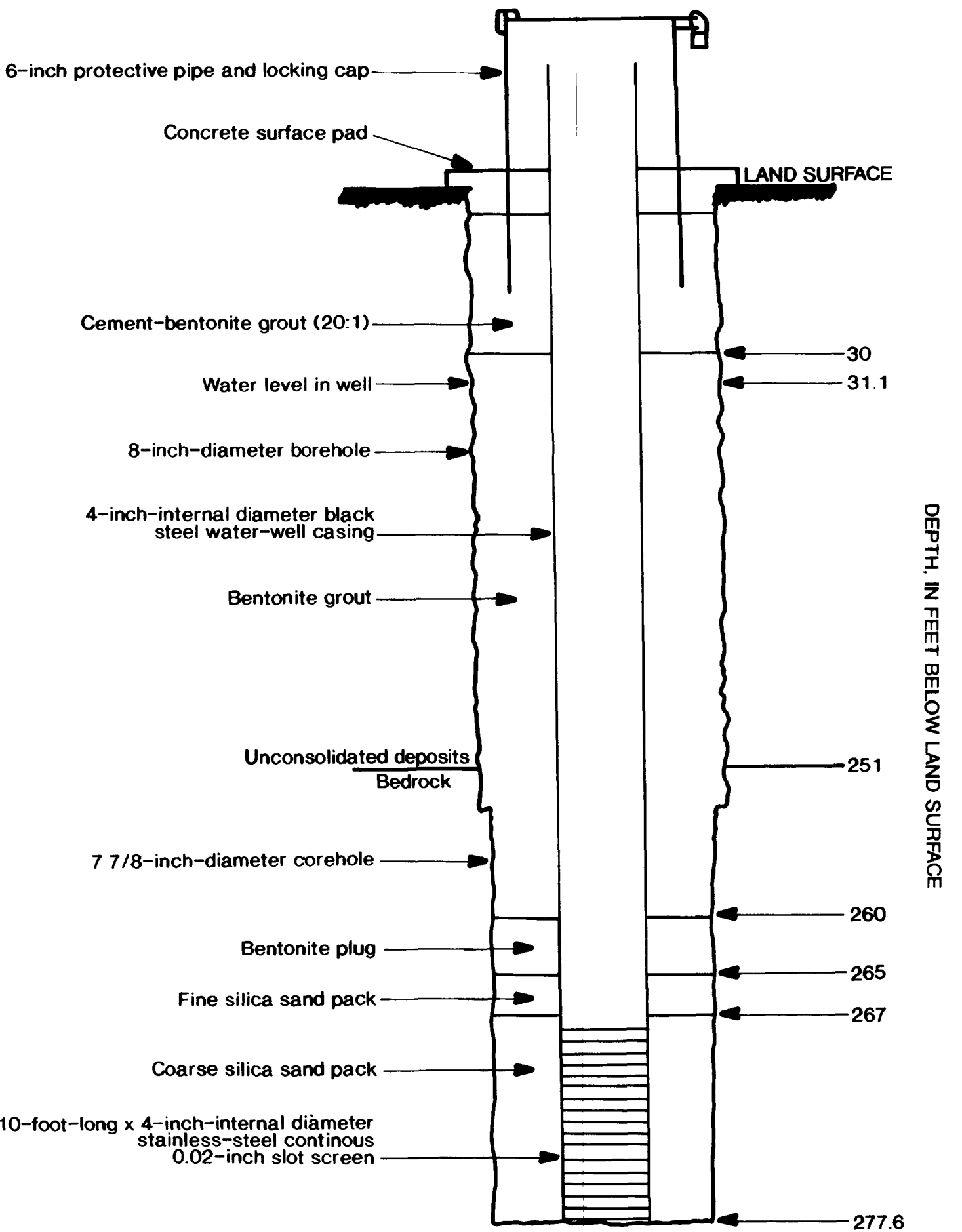

Figure 42.--Construction diagram for well GR-307. 


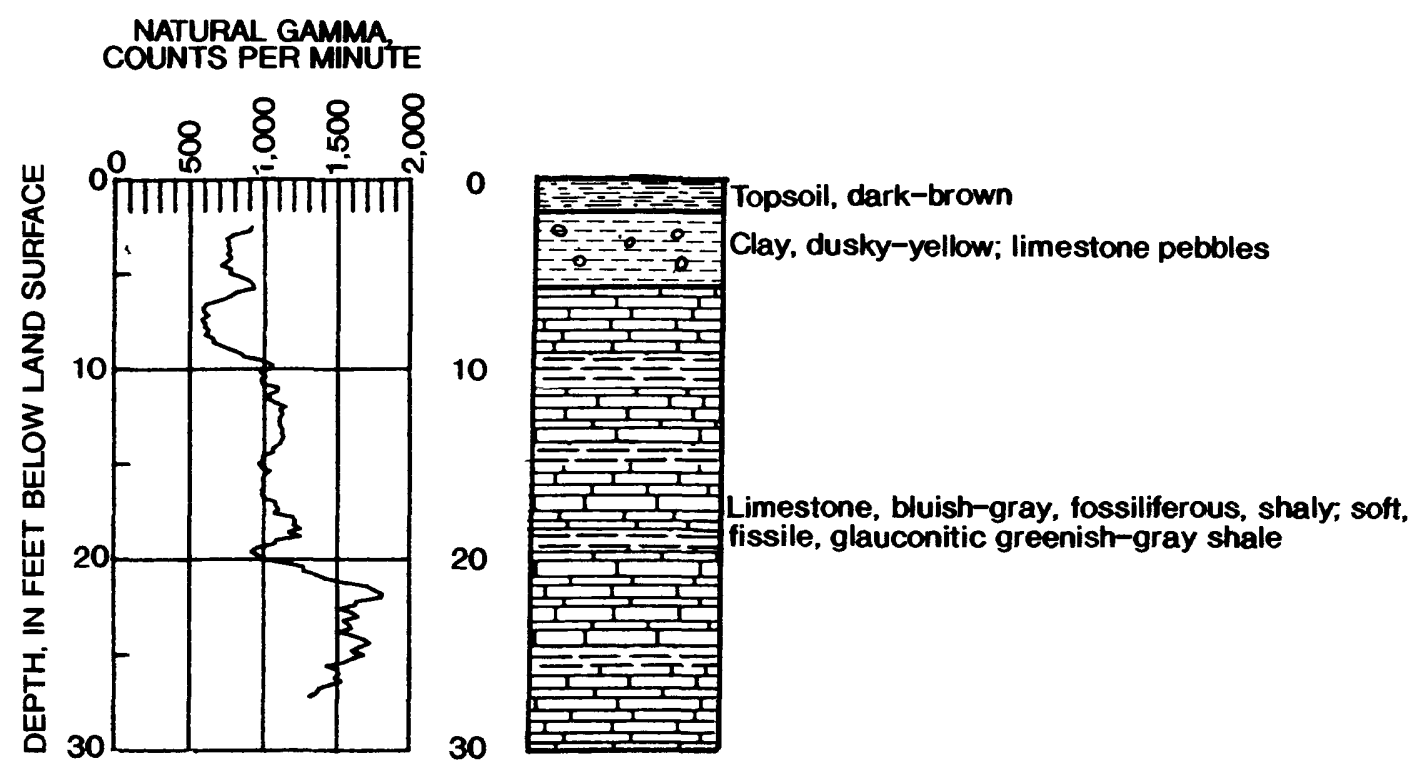

Figure 43.--Natural-gamma and lithologic logs for well GR-308. 


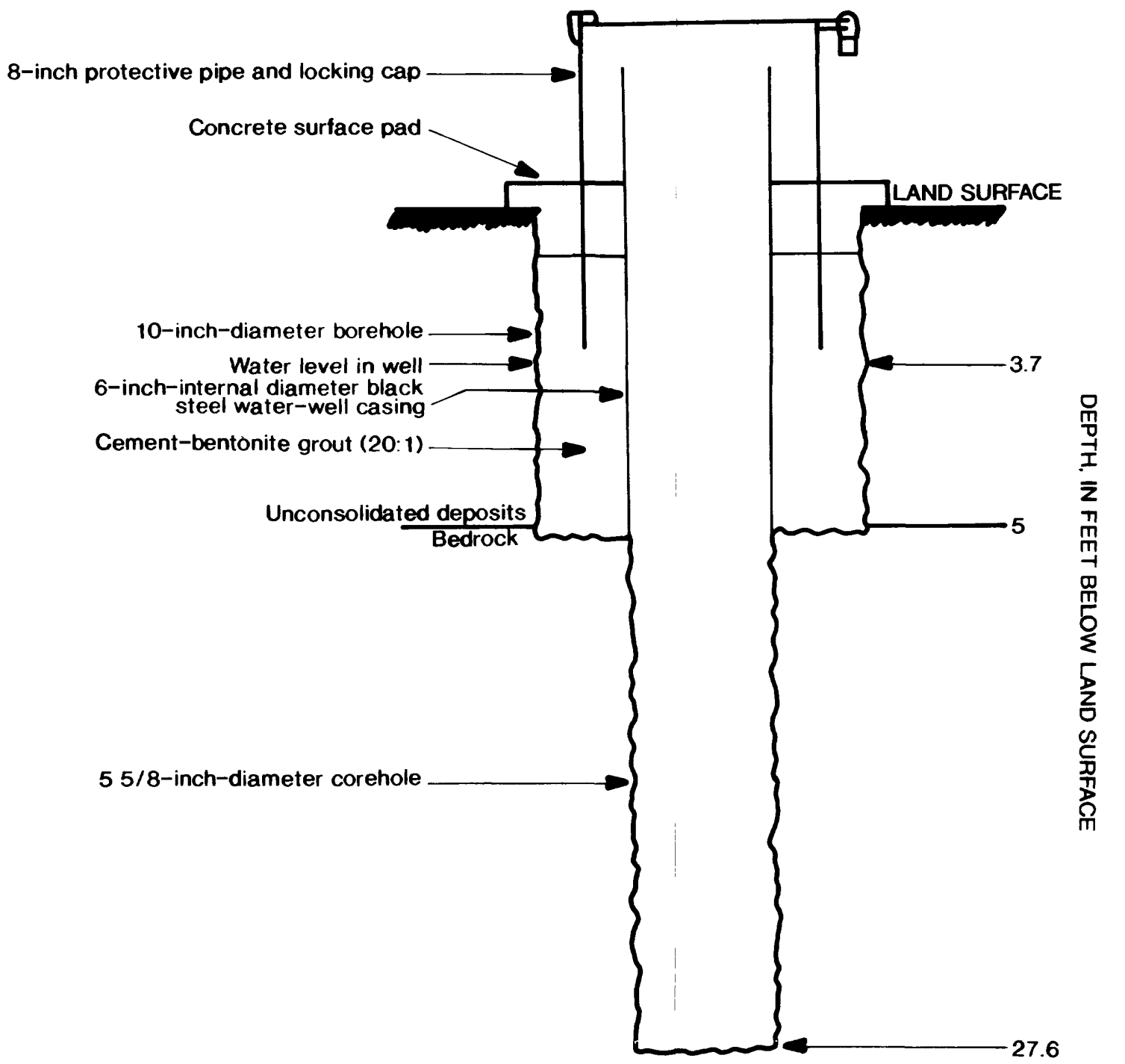

Figure 44.--Construction diagram for well GR-308. 


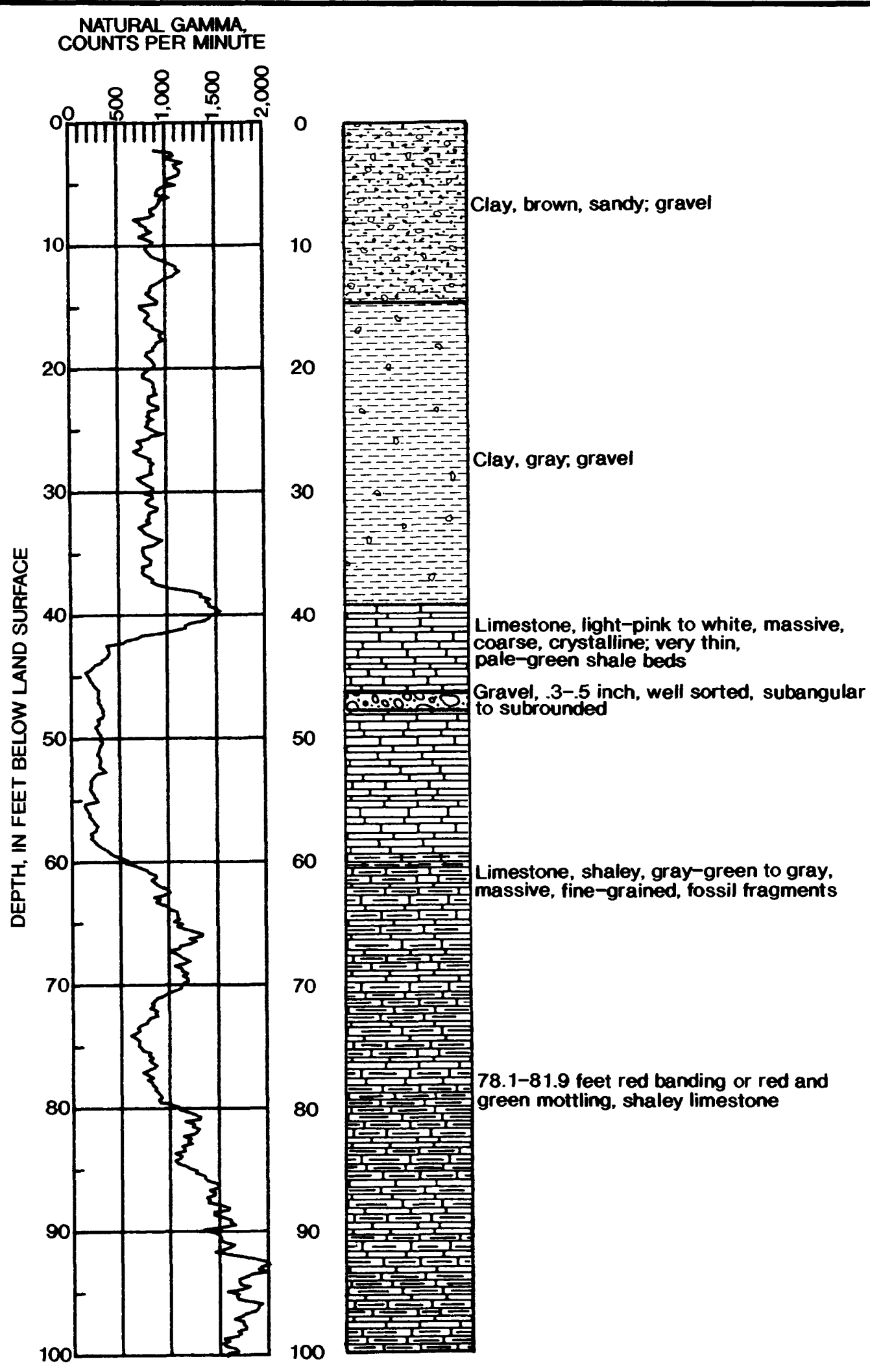

Figure 45.--Natural-gamma and lithologic logs for well GR-312 (cluster 9). 


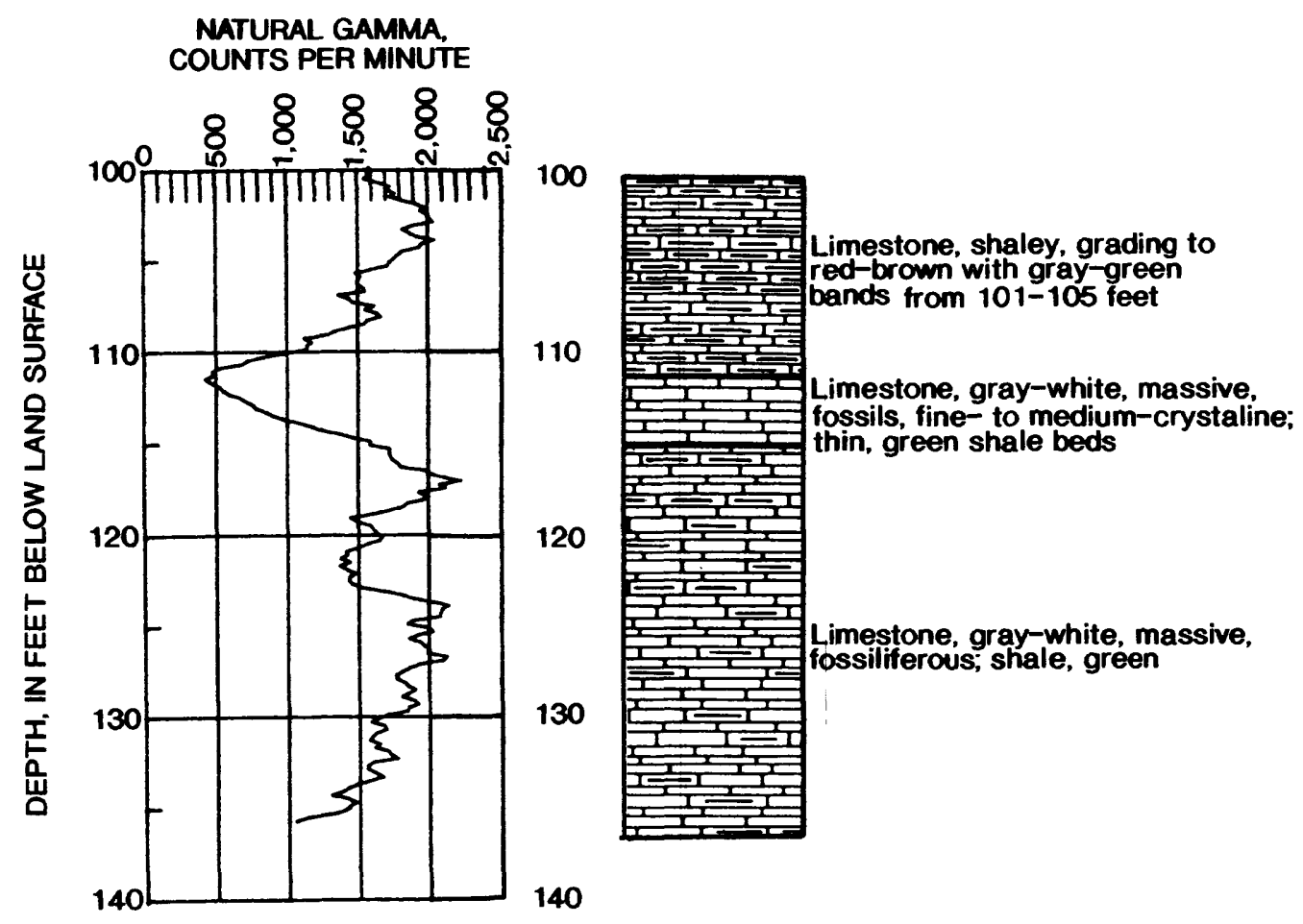

Figure 45.--Natural-gamma and lithologic logs for well GR-312 (cluster 9)--Continued. 


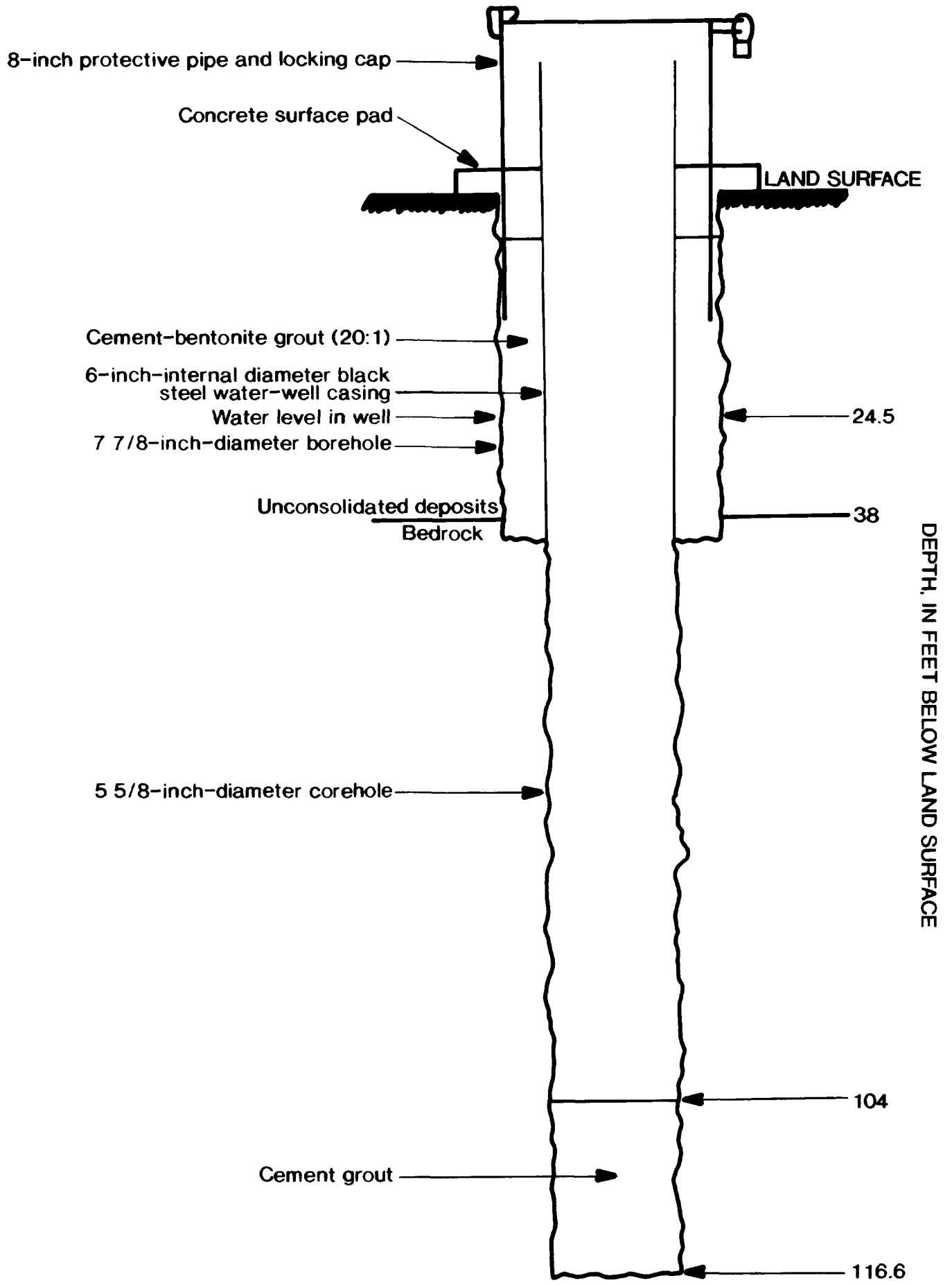

Not to scale

Figure 46.--Construction diagram for well GR-309. 


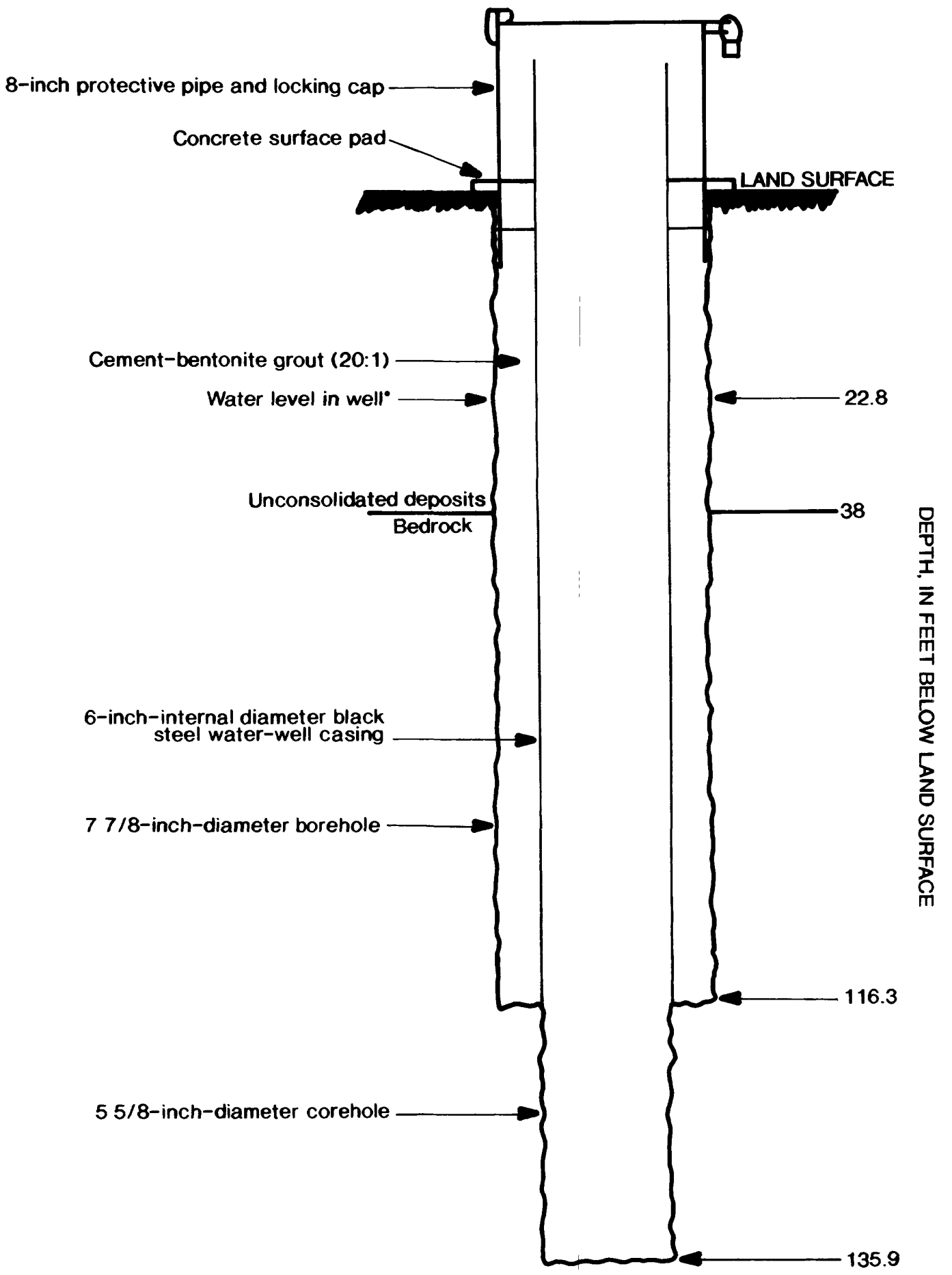

Figure 47.--Construction diagram for well GR-312. 


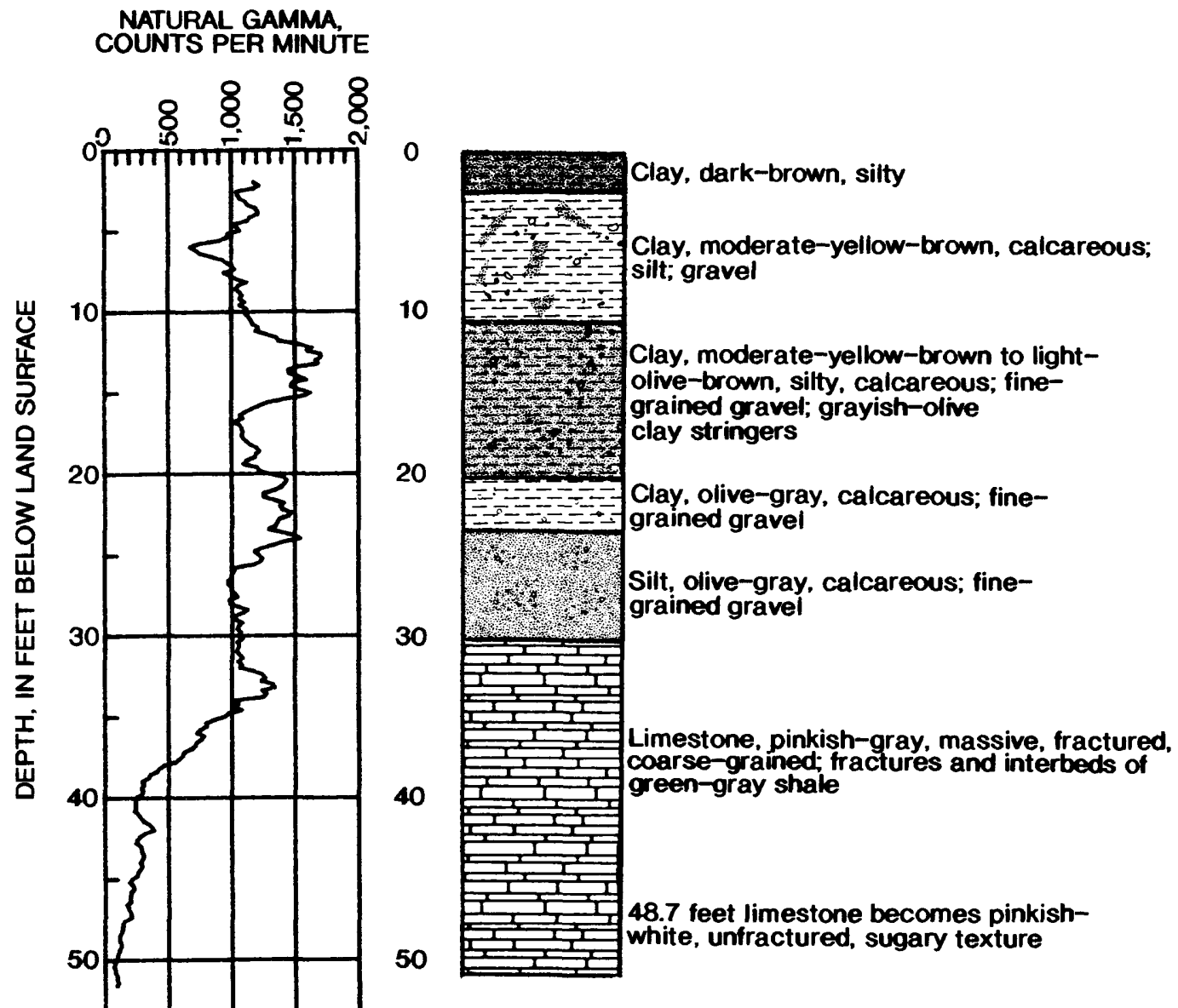

Figure 48.--Natural-gamma and lithologic logs for well GR-310. 


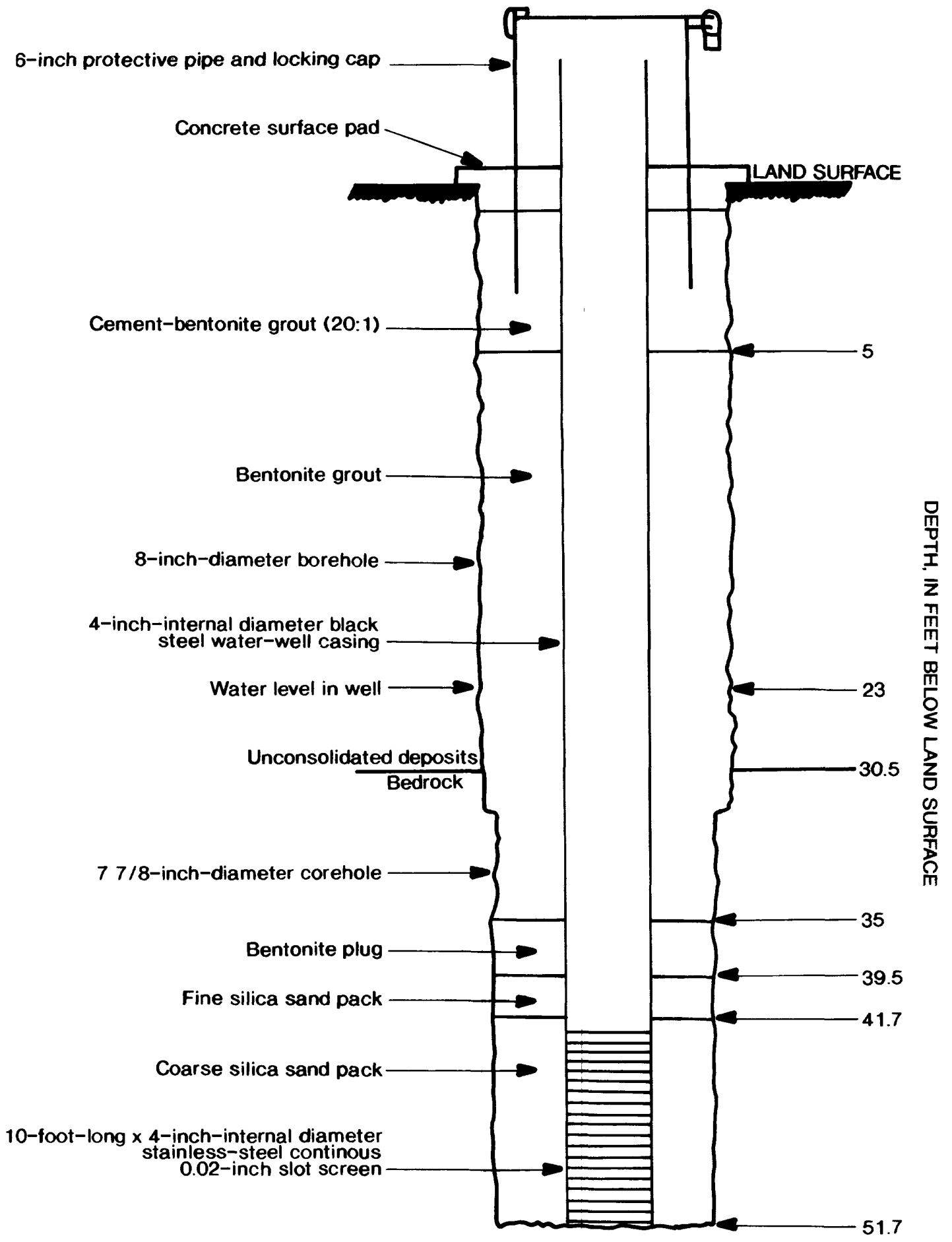

Not to scale

Figure 49.---Construction diagram for well GR-310. 


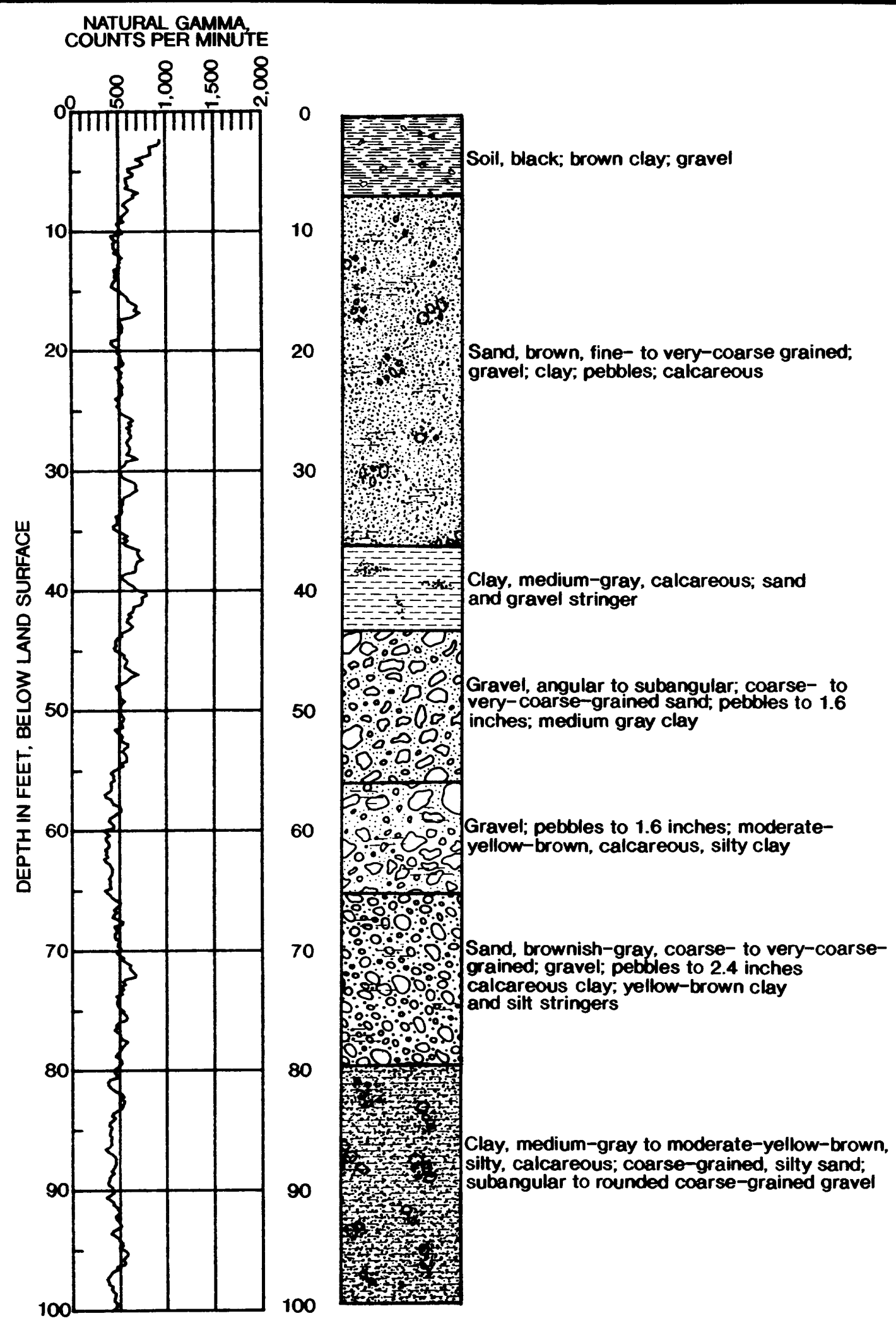

Figure 50.--Natural-gamma and lithologic logs for well GR-311 (cluster 11). 


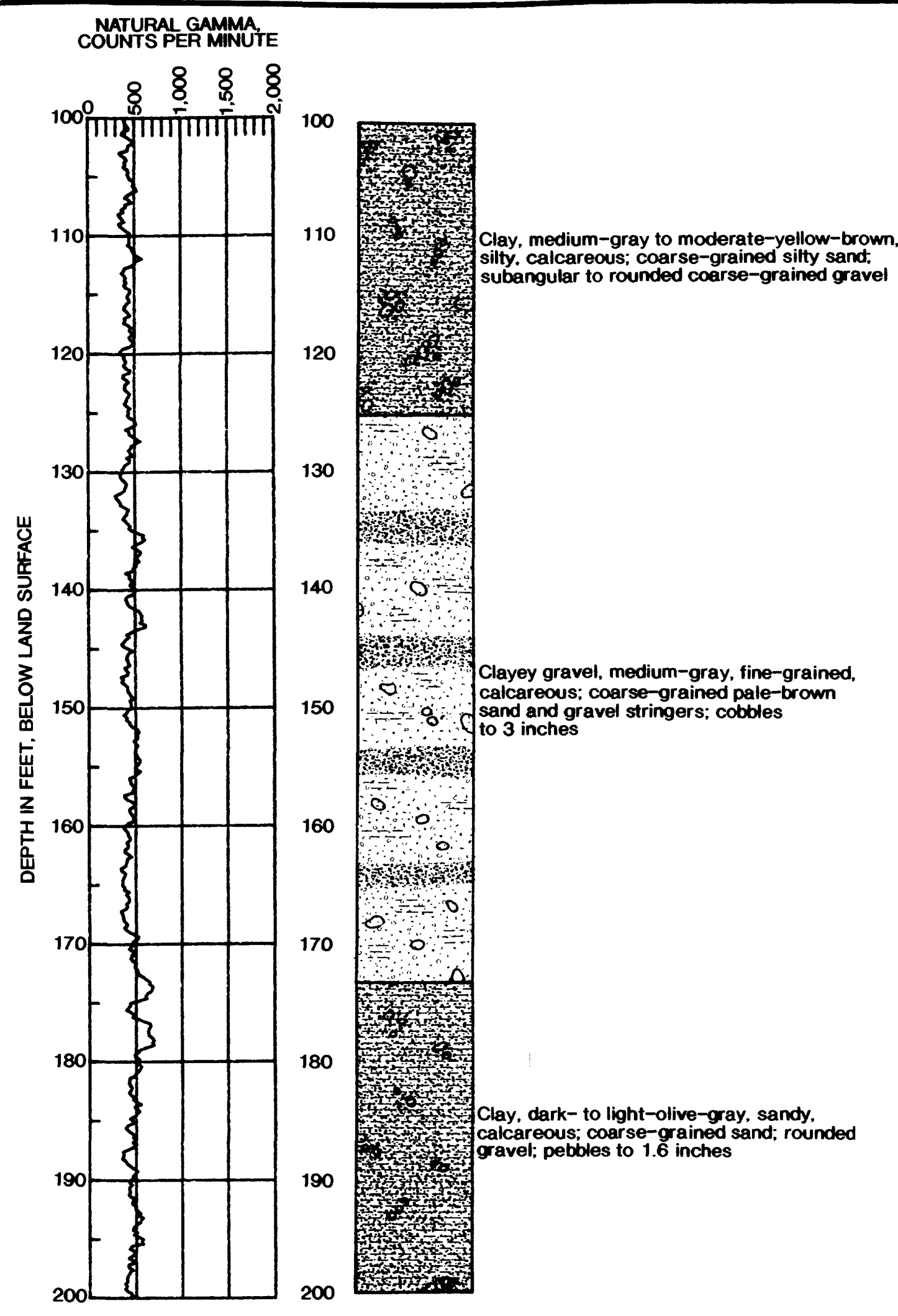

Figure 50.--Natural-gamma and lithologic logs for well GR-311 (cluster 11)--Continued. 


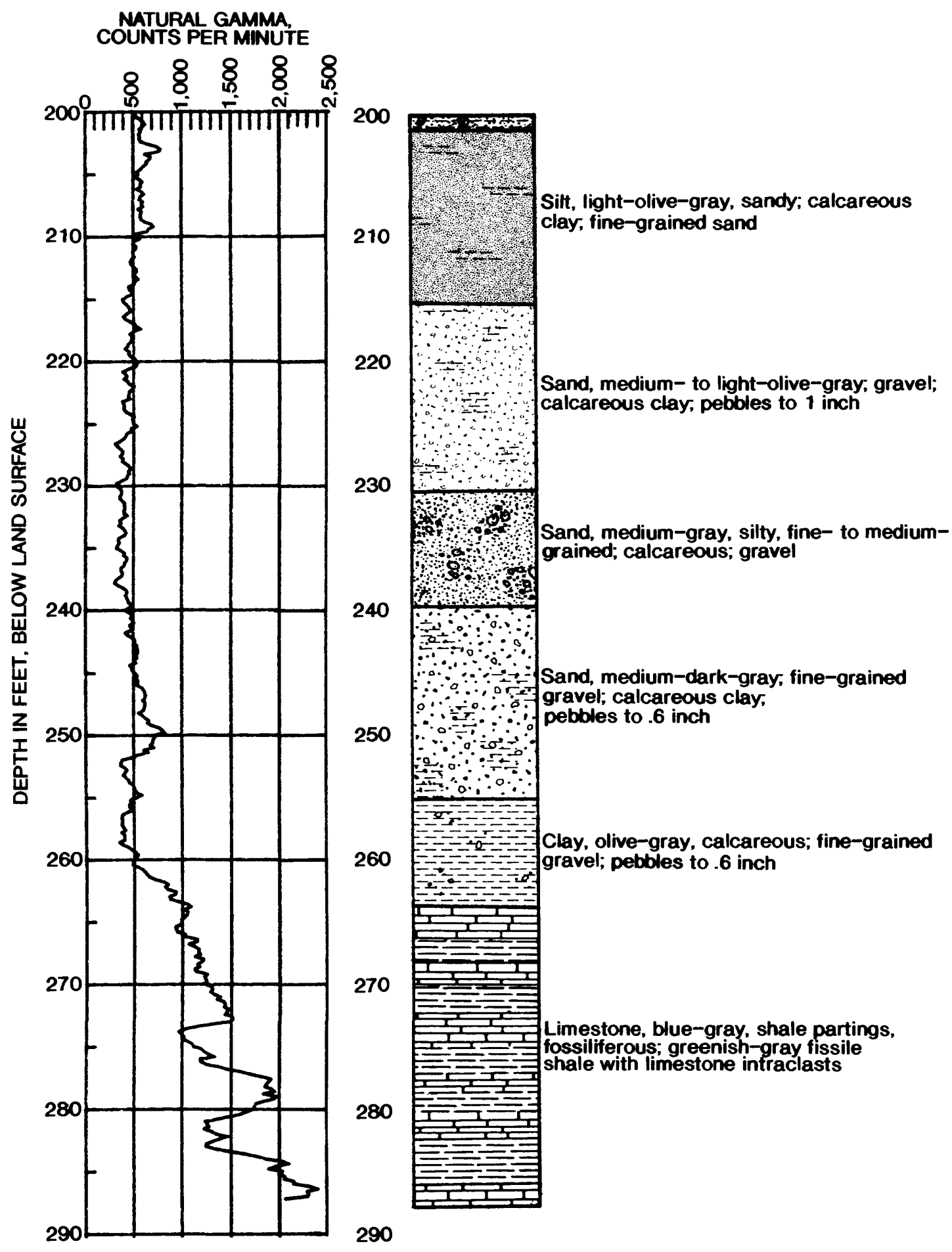

Figure 50.--Natural-gamma and lithologic logs for well GR-311 (cluster 11)--Continued. 


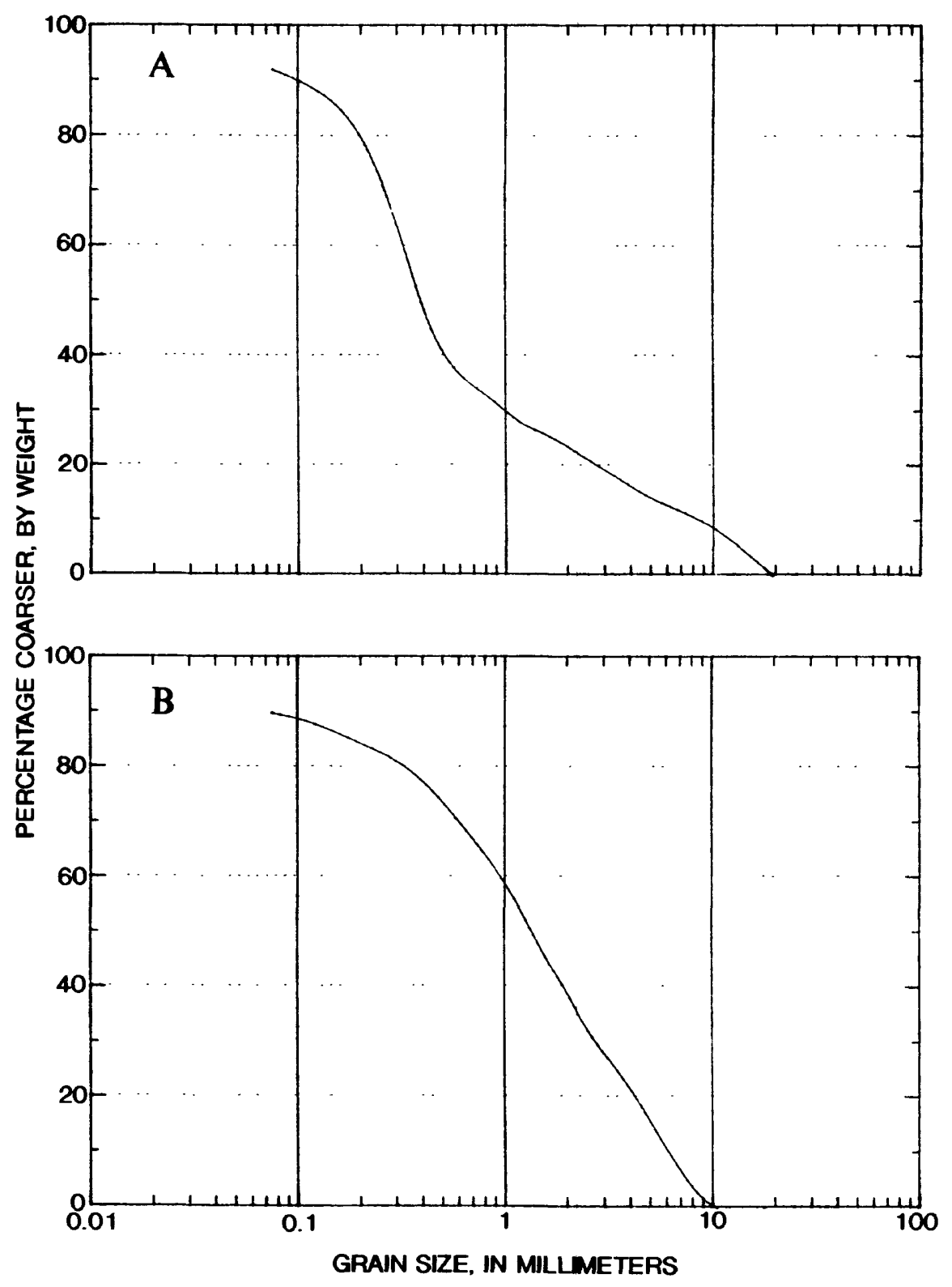

Figure 51.--Grain-size distributions of sediment samples from well GR-311 (cluster 11) (A) 30 to 32 feet and (B) 40.7 to 92.2 feet. 


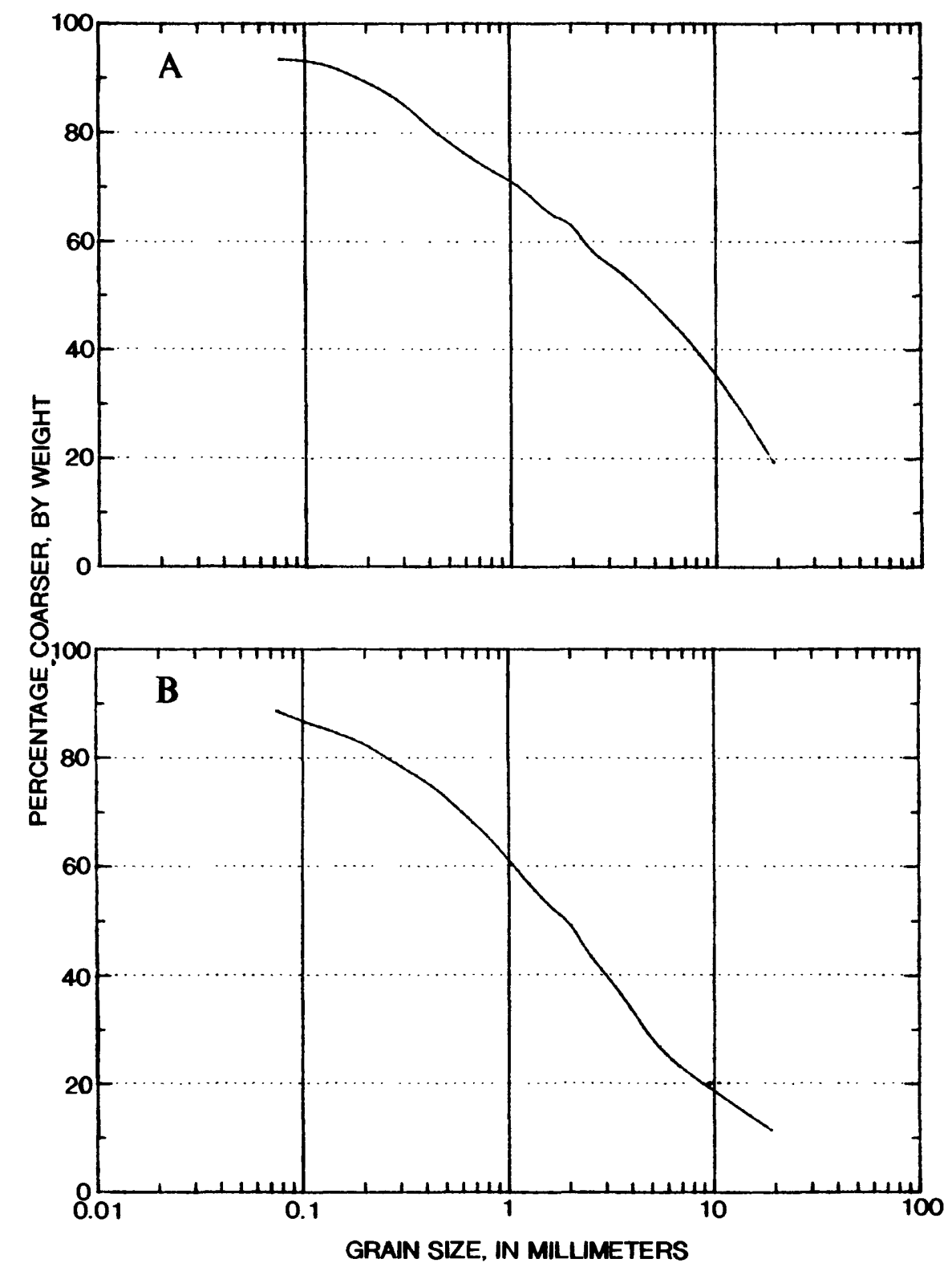

Figure 52.--Grain-size distributions of sediment samples from well GR-311 (cluster 11) (A) 151.8 to 153.2 feet and (B) 195 to 196.3 feet. 


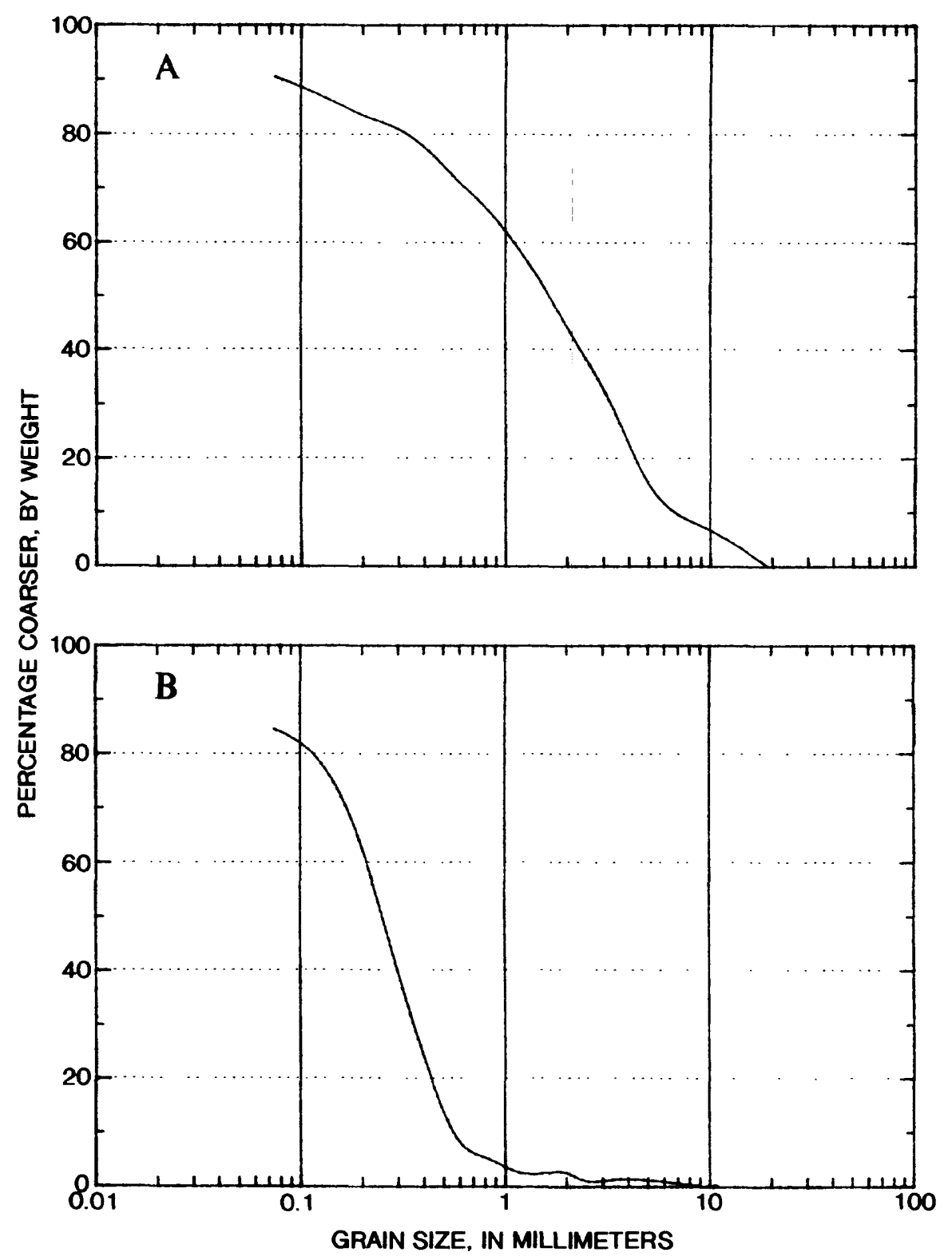

Figure 53.--Grain-size distributions of sediment samples from well GR-311 (cluster 11) (A) 218 to 219 feet and (B) 231.2 to 232.3 feet. 


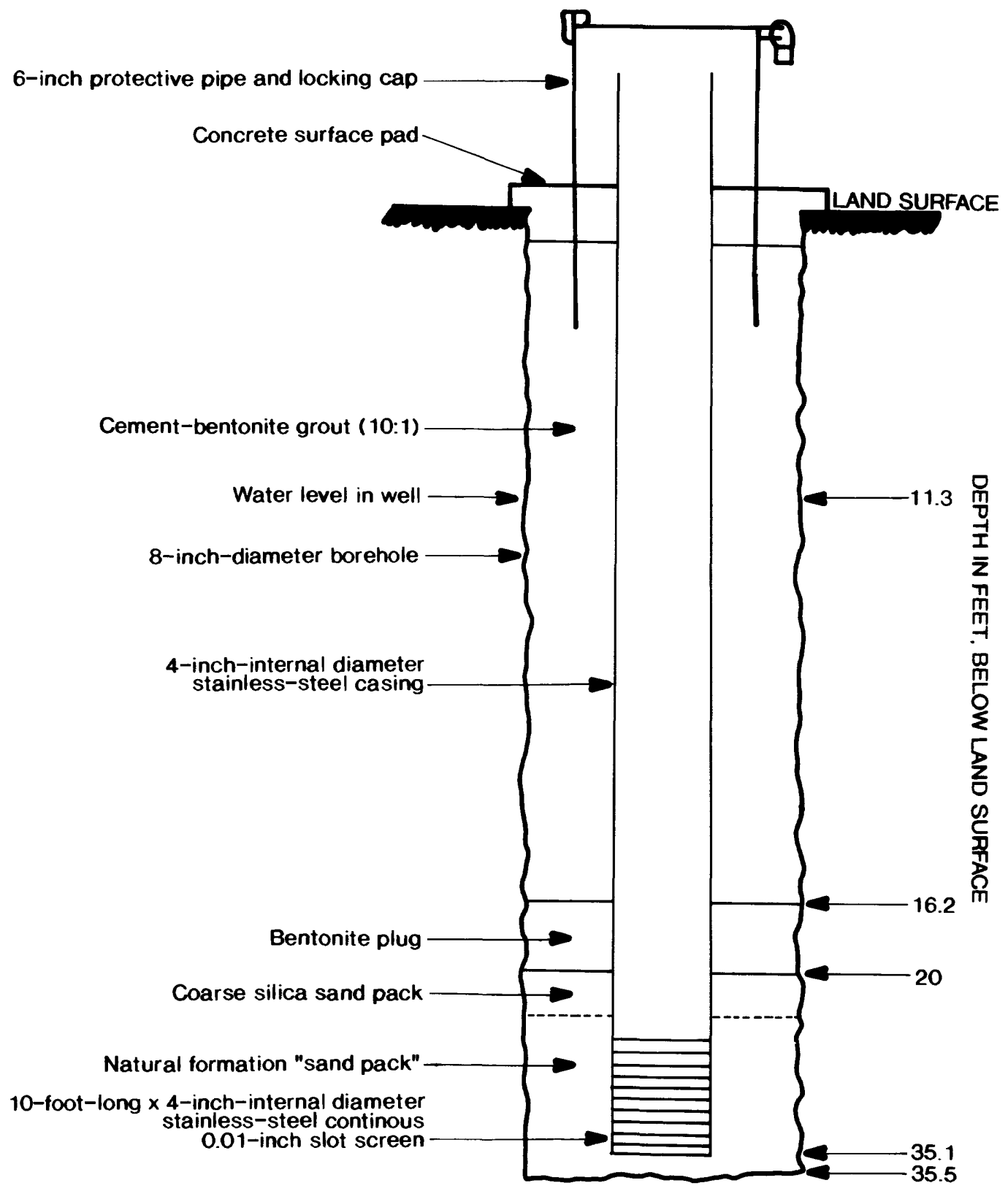

Figure 54.--Construction diagram for well GR-333 


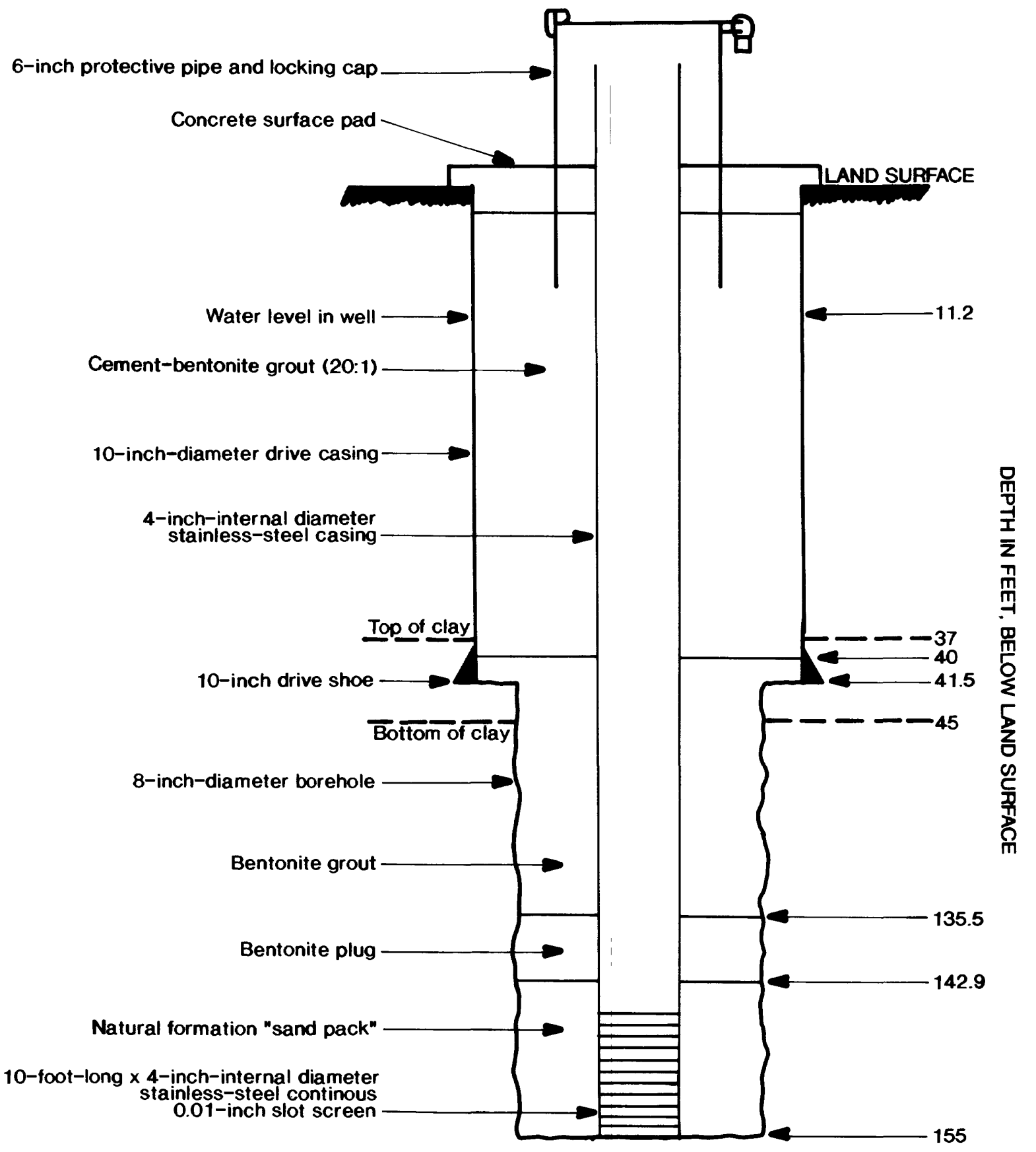

Figure 55.--Construction diagram for well GR-334 


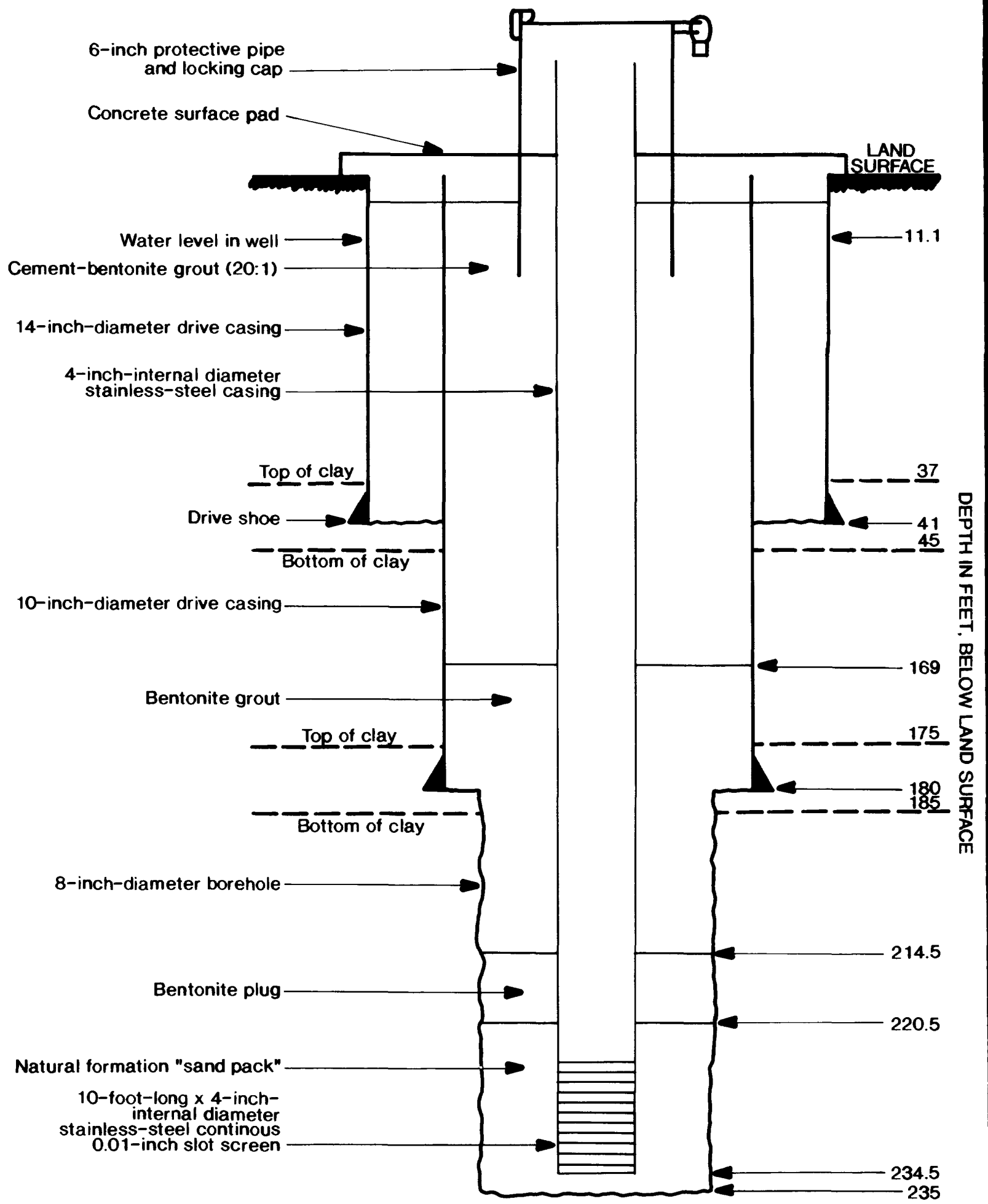

Figure 56.--Construction diagram for well GR-335 


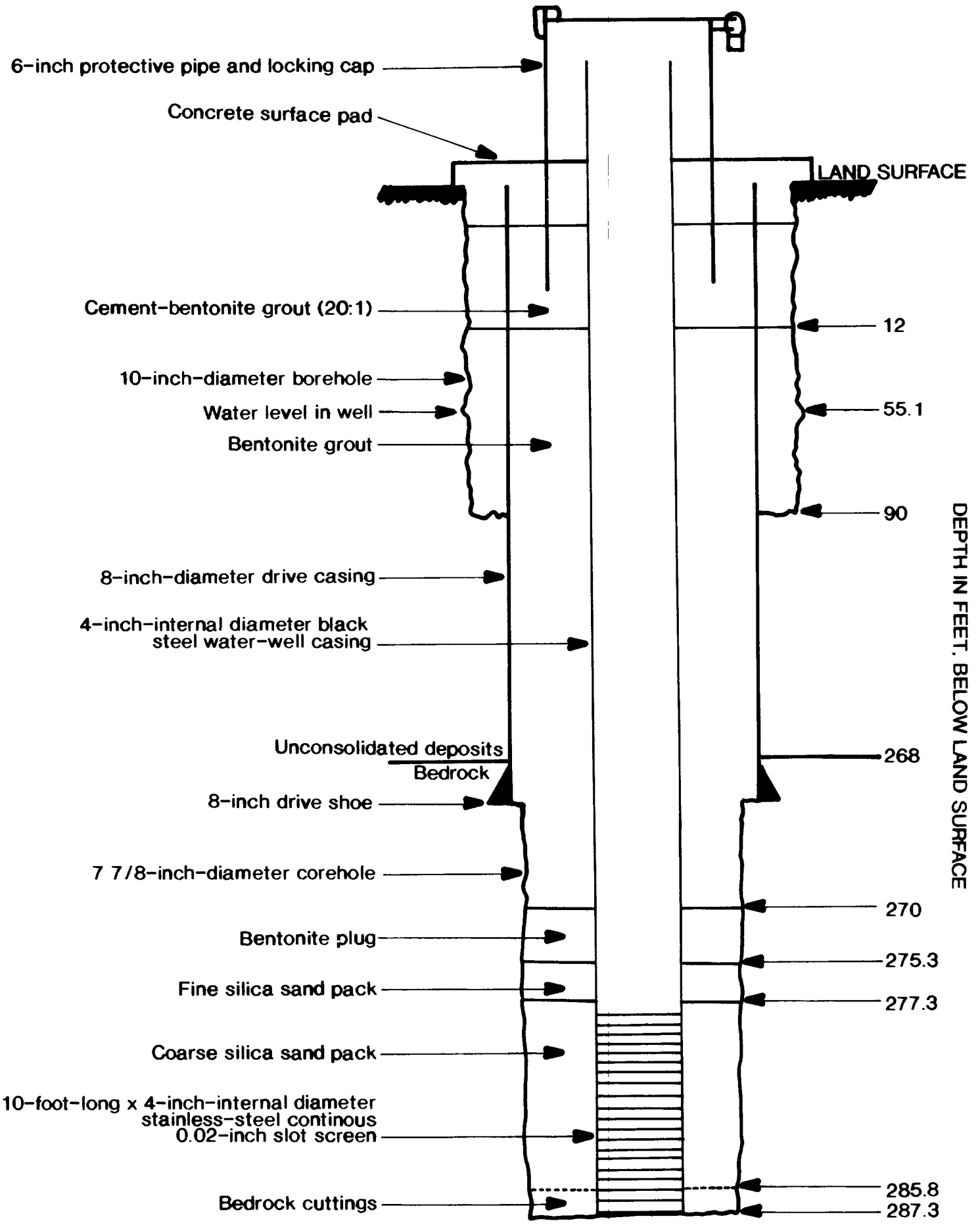

Figure 57.--Construction diagram for well GR-311 


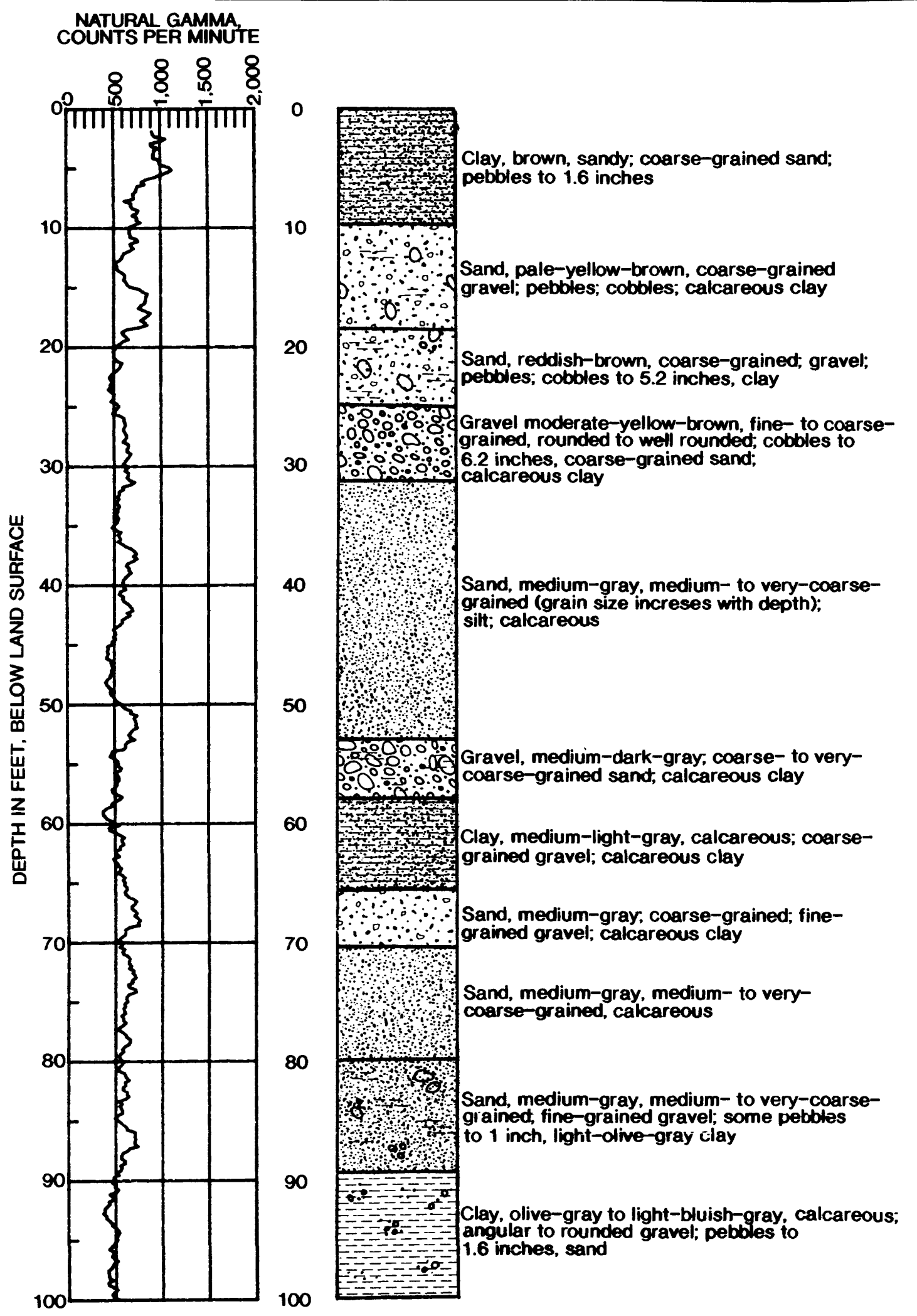

Figure 58.--Natural-gamma and lithologic logs for well MT-133 (cluster 12). 


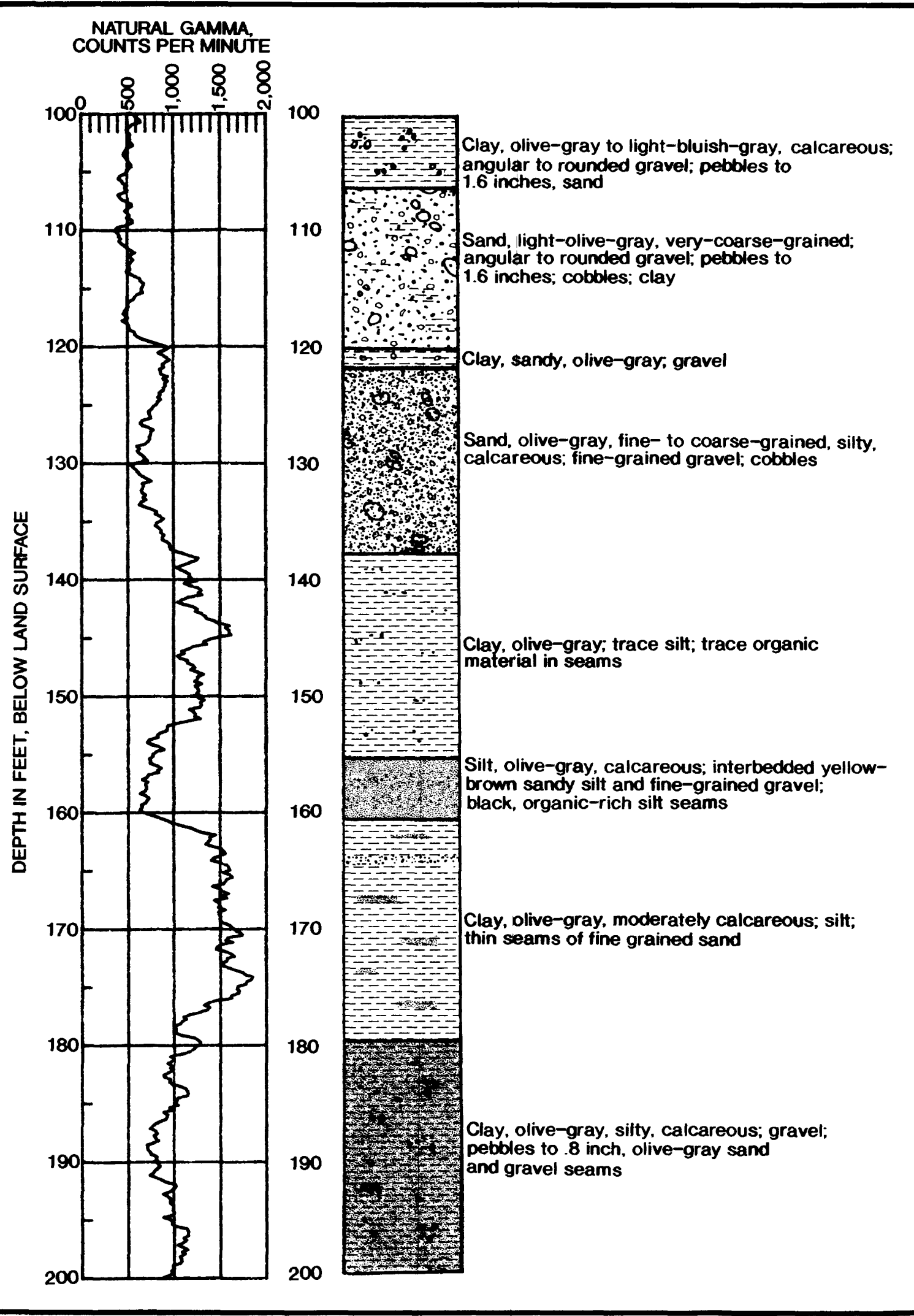

Figure 58.--Natural-gamma and lithologic logs for well MT-133 (cluster 12)--Continued. 


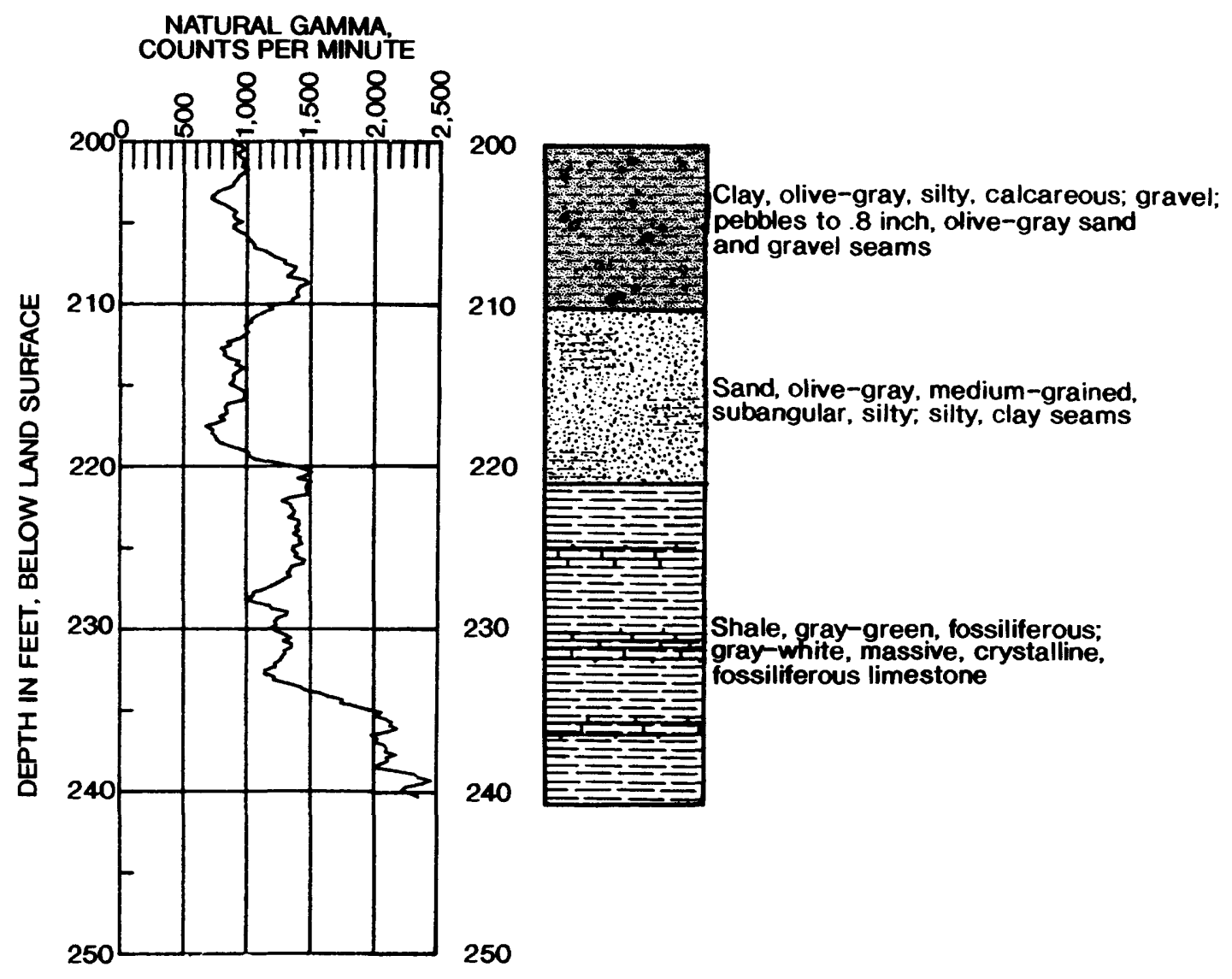

Figure 58.--Natural-gamma and lithologic logs for well MT-133 (cluster 12)--Continued. 


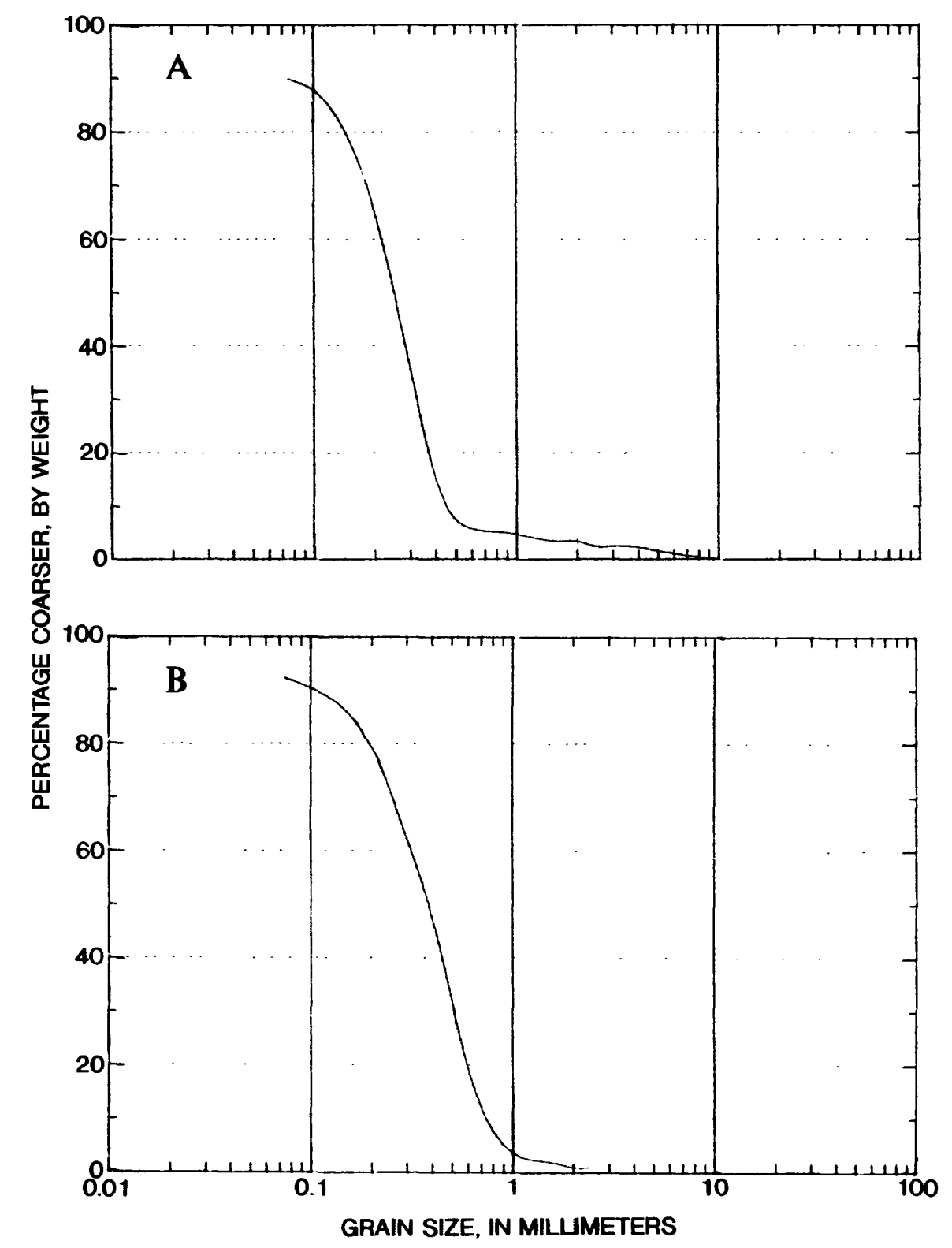

Figure 59.--Grain-size distributions of sediment samples from well MT-133 (cluster 12). (A) 30.5 to 32.2 feet and (B) 50.8 to 52.8 feet. 


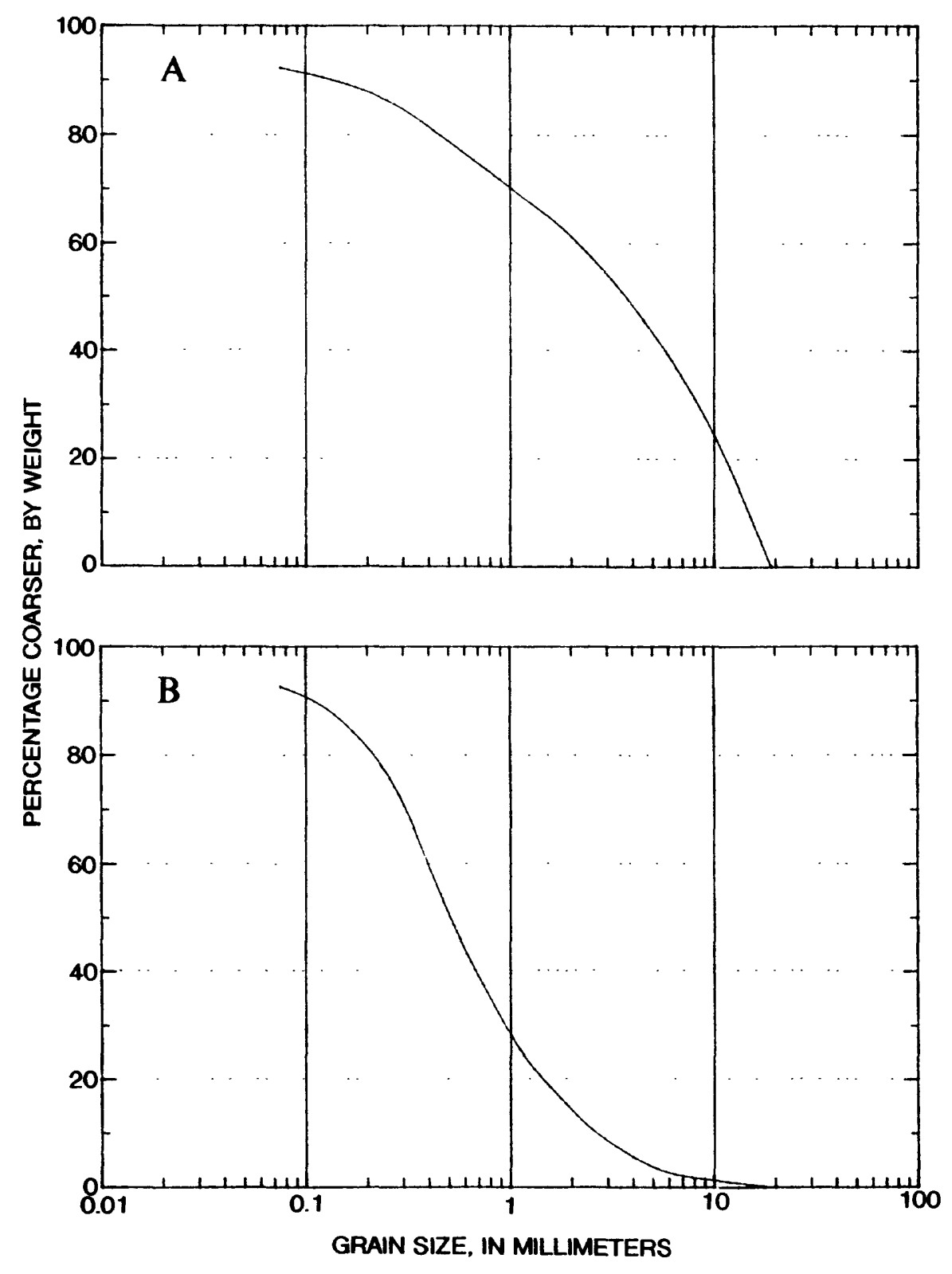

Figure 60.--Grain-size distributions of sediment samples from well MT-133 (cluster 12) (A) 60.4 to 61.2 feet and (B) 86.3 to 88.3 feet. 


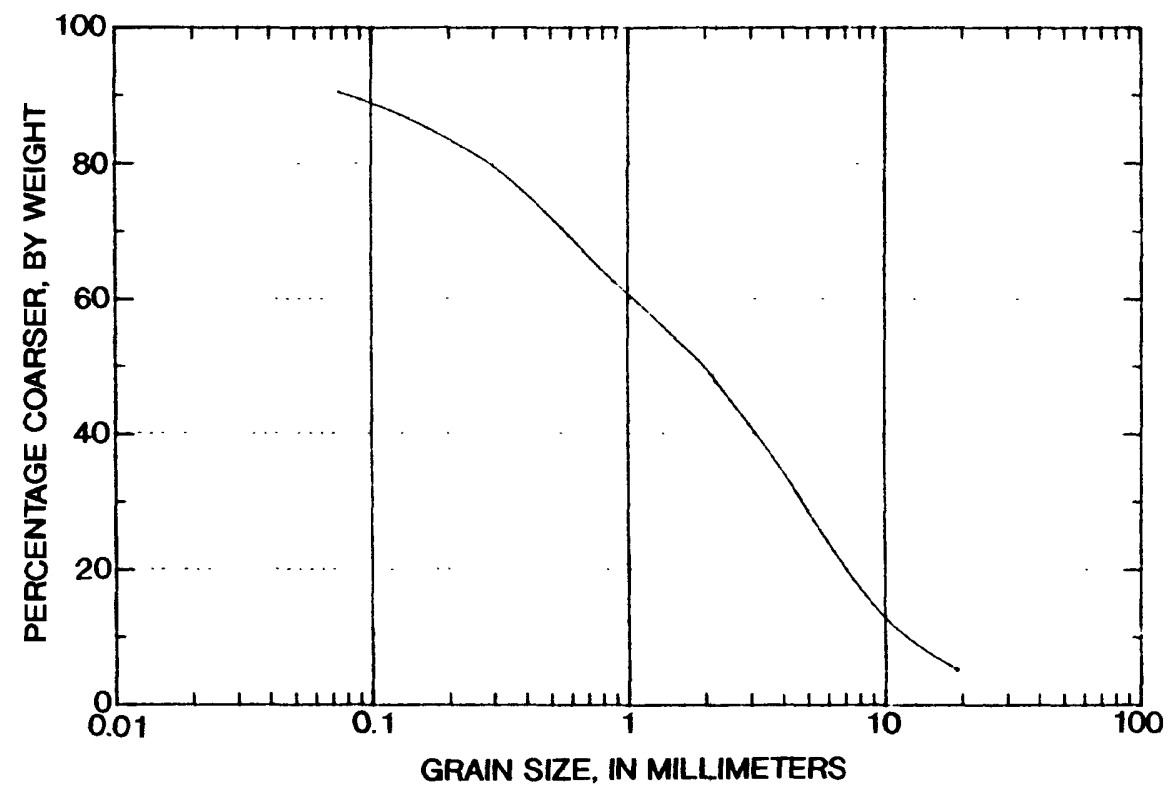

Figure 61.--Grain-size distributions of sediment samples from well MT-133 (cluster 12) 93.5 to 95.2 feet 


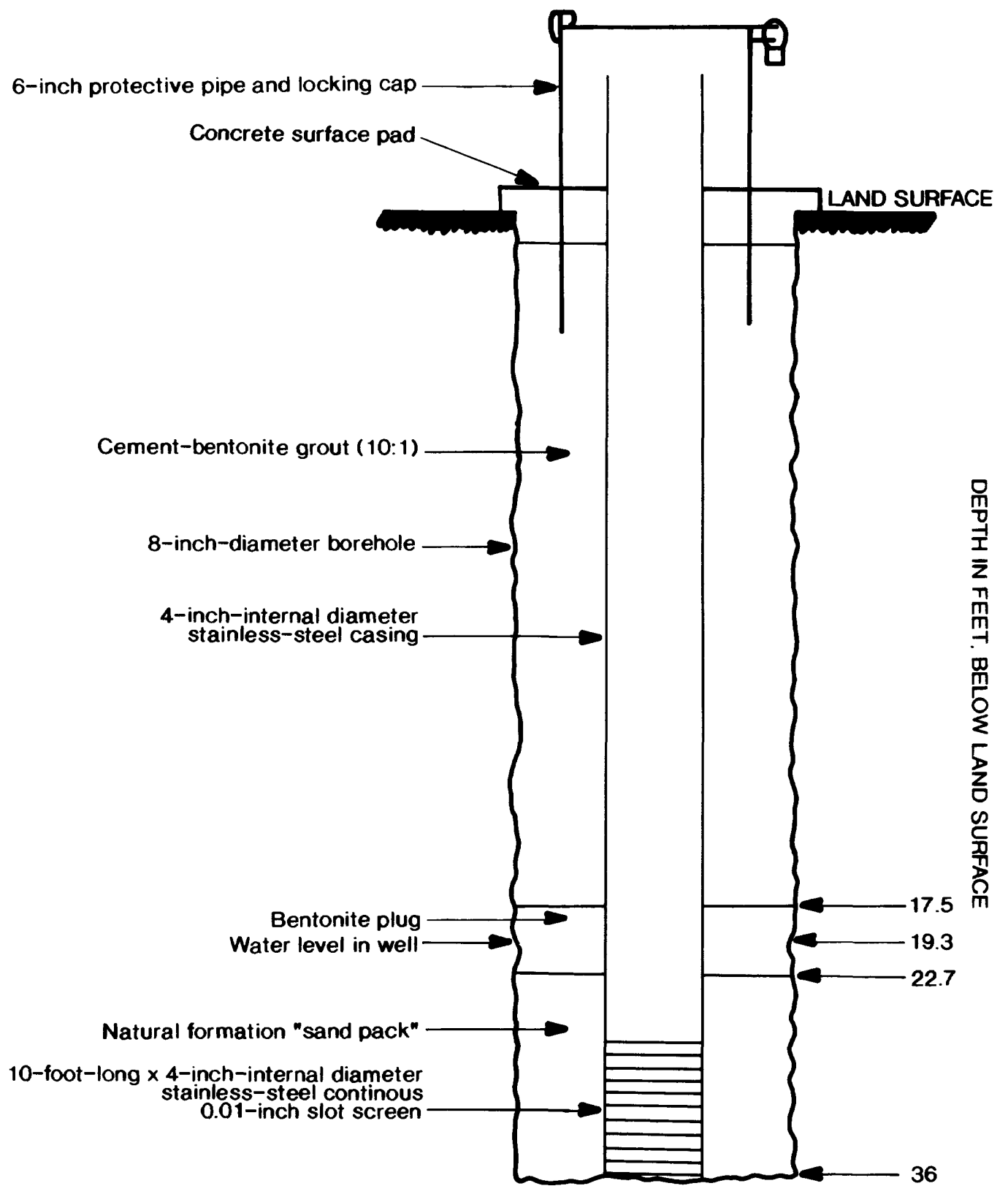

Figure 62.--Construction diagram for well MT-152. 


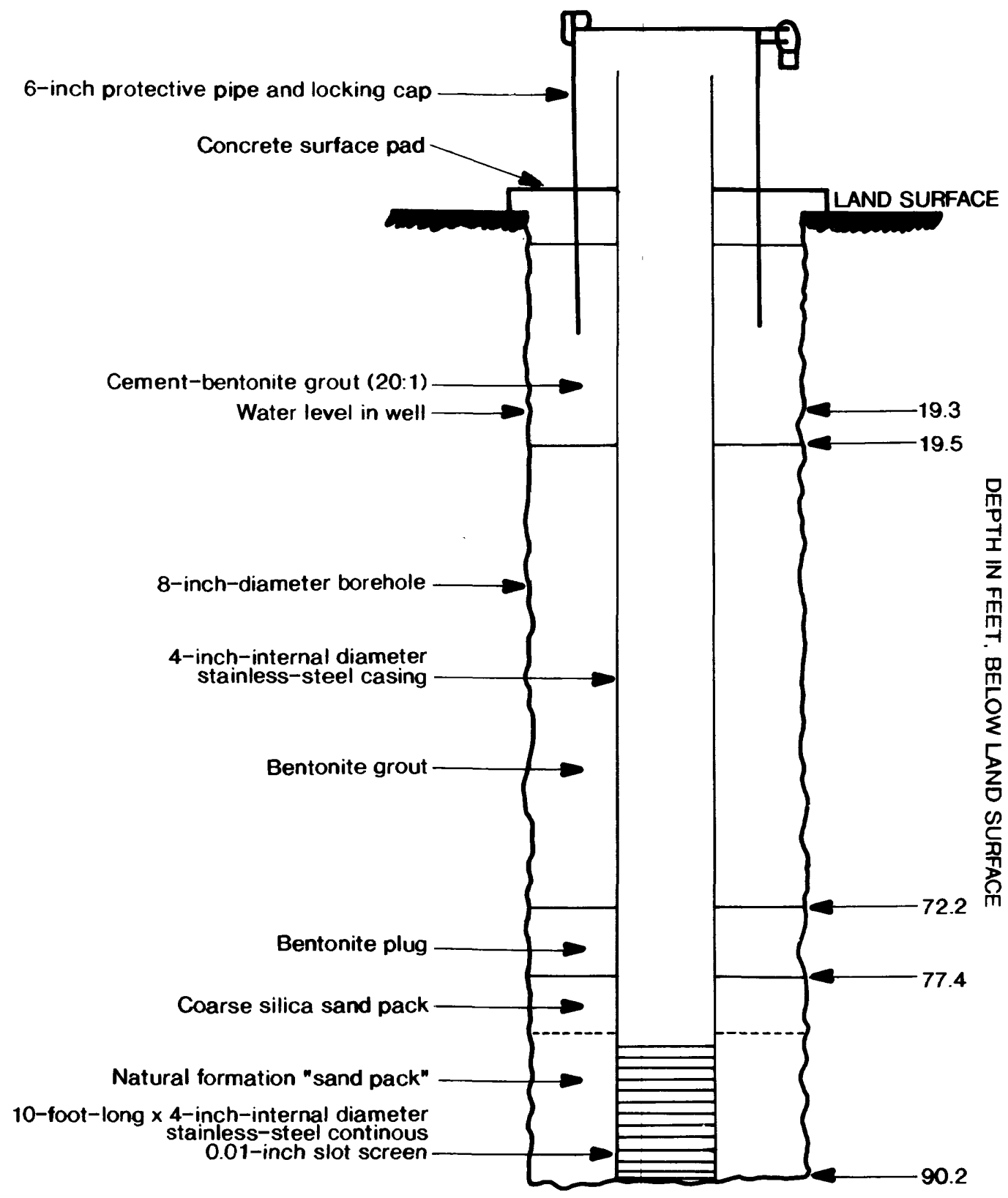

Figure 63.--Construction diagram for well MT- 153. 


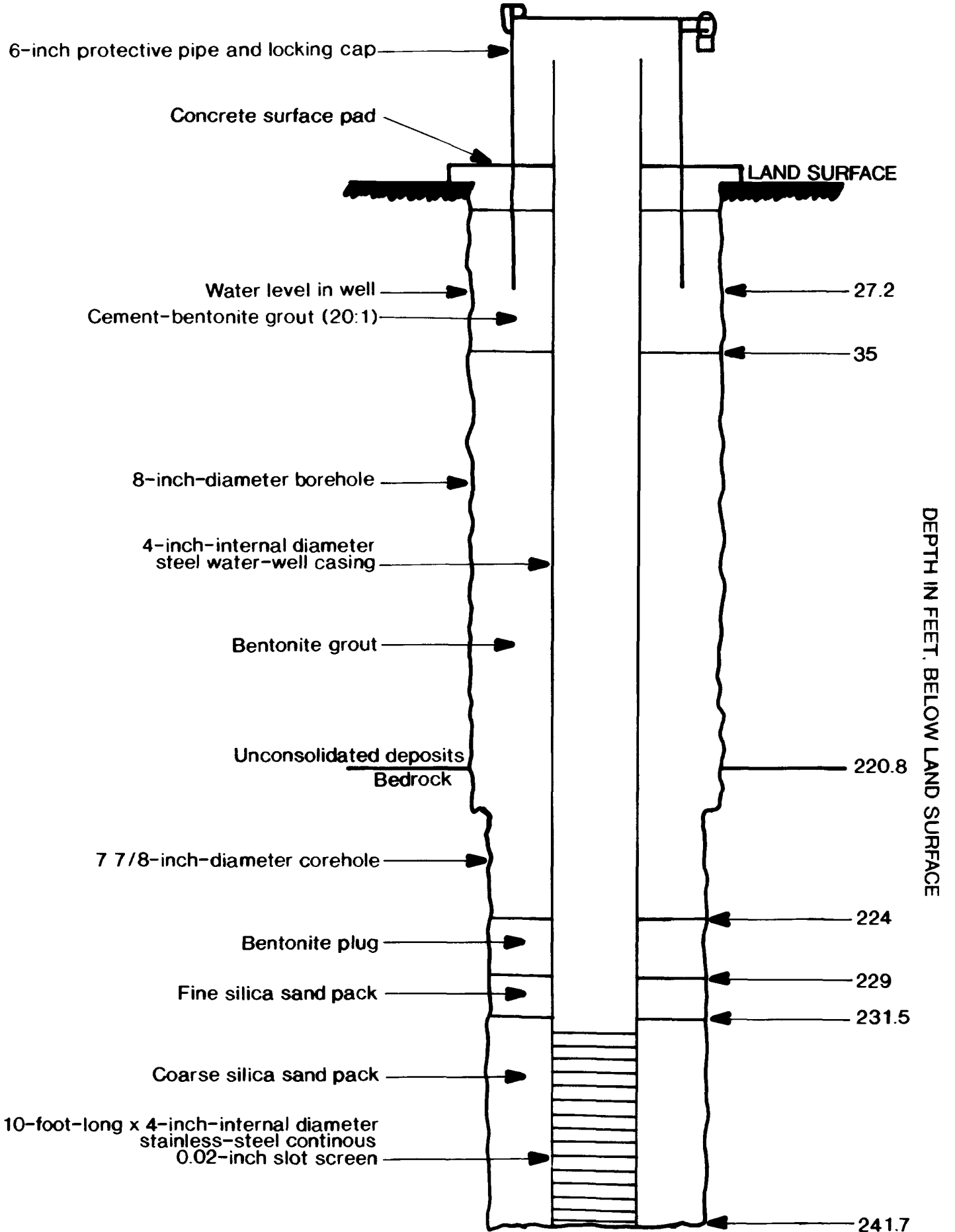

Figure 64.--Construction diagram for well MT-133 


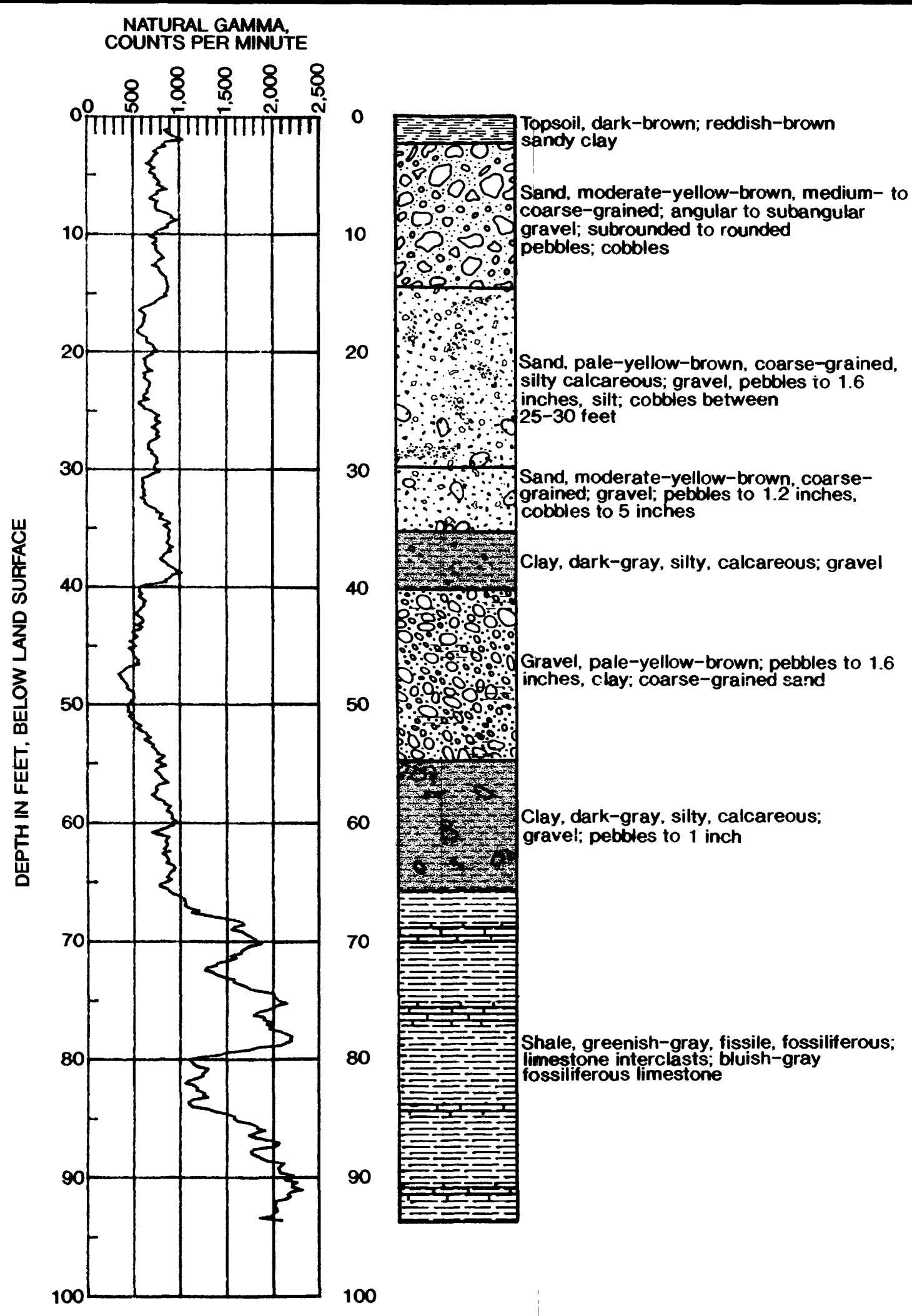

Figure 65.--Natural-gamma and lithologic logs for well GR-313 (cluster 13). 


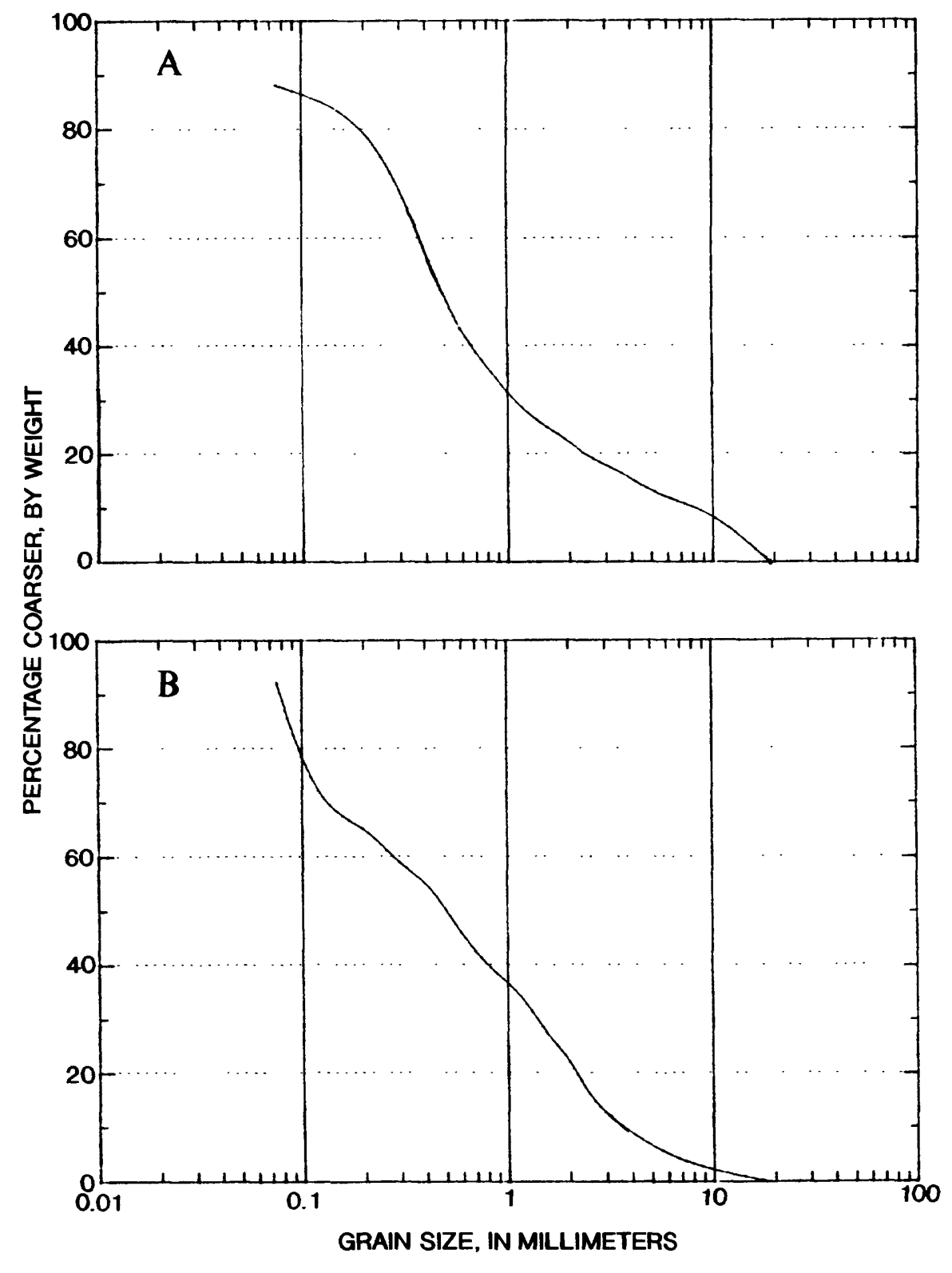

Figure 66.--Grain-size distributions of sediment samples from well GR-313 (cluster 13) (A) 29.7 to 31.1 feet and (B) 50.5 to 51.8 feet. 


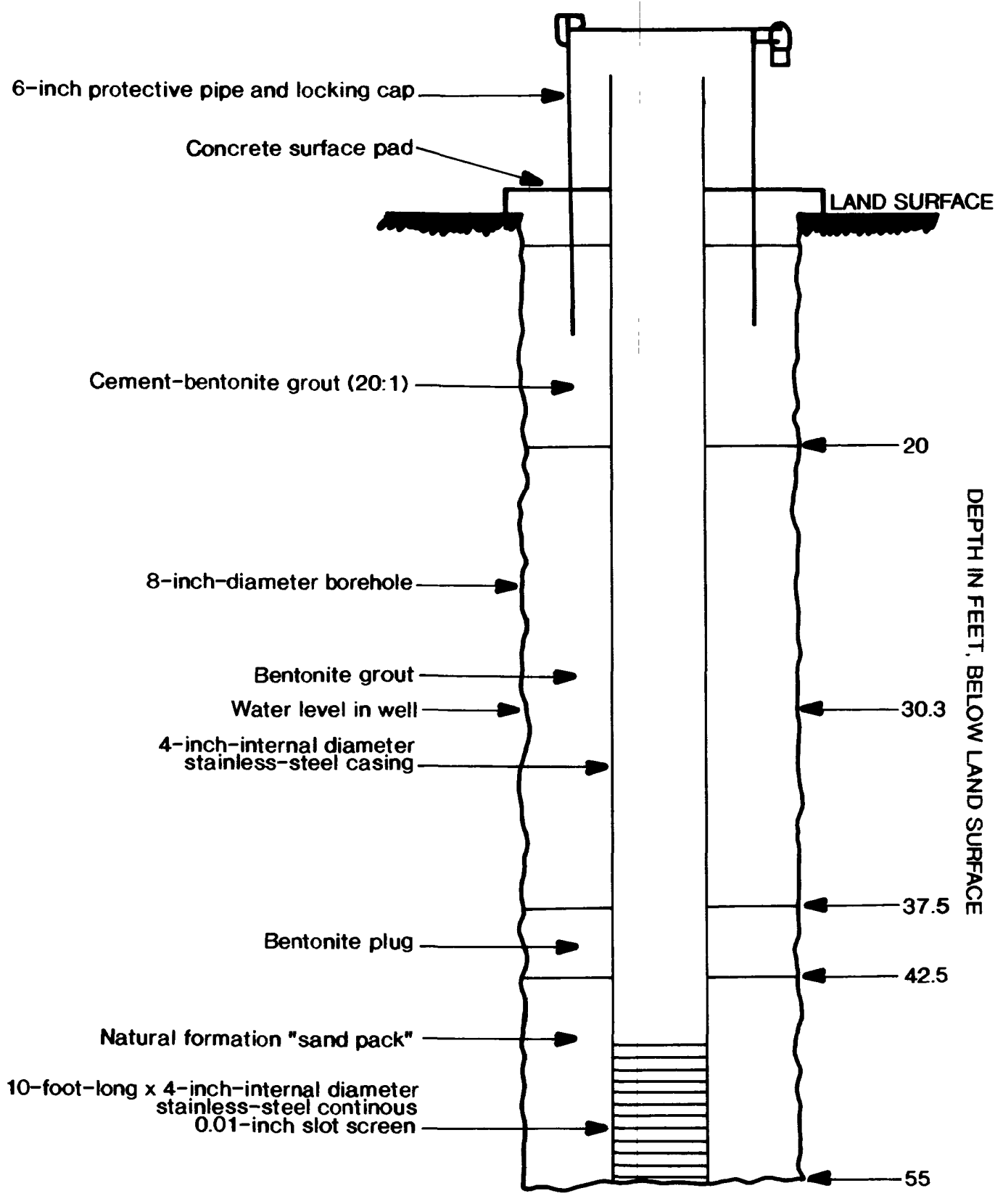

Figure 67.--Construction diagram for well GR-329. 


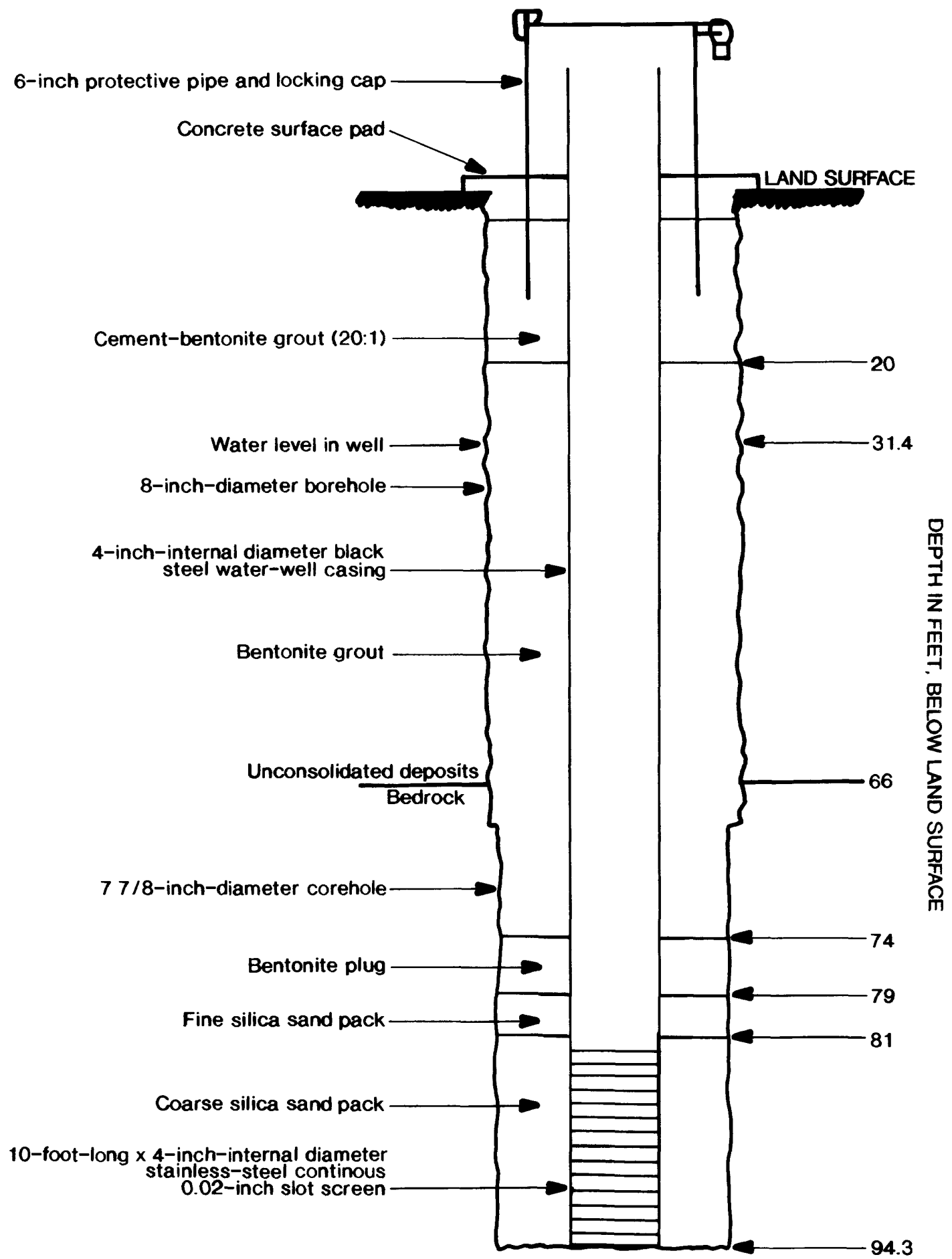

Figure 68.--Construction diagram for well GR-313. 
Alger, R.P., and Harrison, C.W., 1989, Improved fresh water assessment in sand aquifers utilizing geophysical well logs: The Log Analyst, January-February 1989, p. 31-44.

Flint, R.F., 1971, Glacial and Quaternary geology: New York, Wiley, p. 186 .

Norris, S.E., Cross, W.P., and Goldthwait, R.P., 1950, The water resources of Greene County, Ohio: Ohio Department of Natural Resources Division of Water Bulletin 19, 52 p.

Walton, W.C., and Scudder, G.D., 1960, Ground-water resources of the valley-train deposits in the Fairborn area, Ohio: Ohio Department of Natural Resources Division of Water Technical Report 3, 57 p. 